\title{
Newly identified climatically and environmentally significant high latitude dust sources
}

Outi Meinander ${ }^{1}$, Pavla Dagsson-Waldhauserova ${ }^{2,3}$, Pavel Amosov ${ }^{4}$, Elena Aseyeva ${ }^{5}$, Cliff Atkins ${ }^{6}$, Alexander Baklanov ${ }^{7}$, Clarissa Baldo ${ }^{8}$, Sarah Barr ${ }^{9}$, Barbara Barzycka ${ }^{10}$, Liane G. Benning ${ }^{11}$, Bojan 5 Cvetkovic $^{12}$, Polina Enchilik ${ }^{5}$, Denis Frolov ${ }^{5}$, Santiago Gassó ${ }^{13}$, Konrad Kandler ${ }^{14}$, Nikolay Kasimov ${ }^{5}$, Jan Kavan ${ }^{15}$, James King ${ }^{16}$, Tatyana Koroleva ${ }^{5}$, Viktoria Krupskaya ${ }^{5}$, Monika Kusiak ${ }^{17}$, Michał Laska ${ }^{10}$, Jerome Lasne ${ }^{18}$, Marek Lewandowski ${ }^{17}$, Bartłomiej Luks ${ }^{17}$, James B McQuaid ${ }^{9}$, Beatrice Moroni ${ }^{19}$, Benjamin J Murray ${ }^{9}$, Ottmar Möhler ${ }^{20}$, Adam Nawrot ${ }^{17}$, Slobodan Nickovic ${ }^{12}$, Norman T. O’Neill ${ }^{21}$, Goran Pejanovic ${ }^{12}$, Olga B. Popovicheva ${ }^{5}$, Keyvan Ranjbar ${ }^{21}$, Manolis N. Romanias ${ }^{18}$, Olga Samonova ${ }^{5}$,

Alberto Sanchez-Marroquin ${ }^{9}$, Kerstin Schepanski ${ }^{22}$, Ivan Semenkov ${ }^{5}$, Anna Sharapova ${ }^{5}$ Elena Shevnina $^{1}$, Zongbo Shi ${ }^{8}$, Mikhail Sofiev ${ }^{1}$, Frédéric Thevenet ${ }^{18}$, Throstur Thorsteinsson ${ }^{23}$, Mikhail A. Timofeev $^{5}$, Nsikanabasi Silas Umo ${ }^{20}$, Andreas Uppstu ${ }^{1}$, Darya Urupina ${ }^{18}$, György Varga ${ }^{24}$, Tomasz Werner $^{17}$, Olafur Arnalds ${ }^{2}$, and Ana Vukovic Vimic ${ }^{25}$

${ }^{1}$ Finnish Meteorological Institute, Helsinki, 00101, Finland

$15{ }^{2}$ Agricultural University of Iceland, Reykjavik, 112, Iceland

${ }^{3}$ Czech University of Life Sciences Prague, Prague, 16521, Czech Republic

${ }^{4}$ INEP Kola Science Center RAS, Apatity, Russia

${ }^{5}$ Lomonosov Moscow State University, Moscow, 119991, Russia

${ }^{6}$ Te Herenga Waka-Victoria University of Wellington, Wellington, 6012, New Zealand

$20{ }^{7}$ World Meteorological Organization, WMO, Geneva, 1211, Switzerland

${ }^{8}$ University of Birmingham, Birmingham, B15 2TT, United Kingdom

${ }^{9}$ University of Leeds, Leeds, LS2 9JT, United Kingdom

${ }^{10}$ University of Silesia in Katowice, Sosnowiec, 41-200, Poland

${ }^{11}$ German Research Centre for Geosciences, Helmholtz Centre Potsdam, 14473, Germany

$25{ }^{12}$ Republic Hydrometereological Service of Serbia, 11030, Belgrade, Serbia

${ }^{13}$ University of Maryland, College Park MD, 20742, United States of America

${ }^{14}$ Technical University of Darmstadt, Darmstadt, 64287, Germany

${ }^{15}$ Masaryk University, Brno, 61137, Czech Republic

${ }^{16}$ University of Montreal, Montreal, H3T 1J4, Canada

$30 \quad{ }^{17}$ Institute of Geophysics, Polish Academy of Sciences, Warsaw, 01-452, Poland

${ }^{18}$ IMT Lille Douai, SAGE, Université de Lille, 59000 Lille, France

${ }^{19}$ University of Perugia, Perugia, 06123, Italy

${ }^{20}$ Institute of Meteorology and Climate Research, Karlsruhe Institute of Technology, Karlsruhe, 76227, Germany.

${ }^{21}$ Université de Sherbrooke, Sherbrooke, J1K, Canada

$35{ }^{22}$ Free University of Berlin, Berlin, 12165, Germany

${ }^{23}$ University of Iceland, Reykjavik, 102, Iceland

${ }^{24}$ Research Centre for Astronomy and Earth Sciences, Budapest, 1112, Hungary

${ }^{25}$ University of Belgrade, Faculty of Agriculture, Belgrade, 11080, Serbia 
Abstract. Dust particles emitted from high latitudes $\left(\geq 50^{\circ} \mathrm{N}\right.$ and $\geq 40^{\circ} \mathrm{S}$, including Arctic as a subregion $\left.\geq 60{ }^{\circ} \mathrm{N}\right)$, have a potentially large local, regional, and global significance to climate and environment as short-lived climate forcers, air pollutants and nutrient sources. To understand the multiple impacts of the High Latitude Dust (HLD) on the Earth systems, it is foremost to identify the geographic locations and characteristics of local dust sources. Here, we identify, describe, and quantify the Source Intensity (SI) values using the Global Sand and Dust Storms Source Base Map (G-SDS-SBM), for sixty-four HLD sources included in our collection in the Northern (Alaska, Canada, Denmark, Greenland, Iceland, Svalbard, Sweden, and Russia) and Southern (Antarctica and Patagonia) high latitudes. Activity from most of these HLD dust sources show seasonal character. The environmental and climatic effects of dust on clouds and climatic feedbacks, atmospheric chemistry, marine environment, and cryosphere-atmosphere feedbacks at high latitudes are discussed, and regional-scale modelling of dust atmospheric transport from potential Arctic dust sources is demonstrated. It is estimated that high latitude land area with higher (SI $\geq 0.5)$, very high $(\mathrm{SI} \geq 0.7)$ and the highest potential $(\mathrm{SI} \geq 0.9)$ for dust emission cover $>1670000 \mathrm{~km}^{2},>560000 \mathrm{~km}{ }^{2}$, and $>240000 \mathrm{~km}^{2}$, respectively. In the Arctic HLD region, land area with $\mathrm{SI} \geq 0.5$ is $5.5 \%$ (1035 $\left.059 \mathrm{~km}^{2}\right)$, area with $\mathrm{SI} \geq 0.7$ is 2.3 $\%\left(440804 \mathrm{~km}^{2}\right)$, and with $\mathrm{SI} \geq 0.9$ it is $1.1 \%\left(208701 \mathrm{~km}^{2}\right)$. Minimum SI values in the north HLD region are about three orders of magnitude smaller, indicating that the dust sources of this region are highly dependable on weather conditions. In the south HLD region, soil surface conditions are favourable for dust emission during the whole year. Climate change can cause decrease of snow cover duration, retrieval of glaciers, permafrost thaw, and increase of drought and heat waves intensity and frequency, which all lead to the increasing frequency of topsoil conditions favourable for dust emission and thereby increasing probability for dust storms. Our study provides a step forward to improve the representation of HLD in models and to monitor, quantify and assess the environmental and climate significance of HLD in the future.

\section{Introduction}

Mineral dust is often associated with hot, subtropical deserts, but importance of dust sources in the cold high latitudes $(\geq 50$ ${ }^{\circ} \mathrm{N}$ and $\geq 40^{\circ} \mathrm{S}$, including Arctic as a subregion $\geq 60^{\circ} \mathrm{N}$ ) has recently increased (Arnalds et al., 2016; Bachelder et al., 2020;

65 Boy et al., 2019; Bullard et al., 2016; Cosentino et al., 2020; Gasso and Torres, 2019; Groot Zwaafting et al., 2016, 2017; IPCC, 2019; Kavan et al., 2018, 2020a,b; Ranjbar et al., 2020; Sanchez-Marroqin et al., 2020; Tobo et al., 2019). Mineral dust is transported from local high latitude dust (HLD) and low latitude dust (LLD) sources to high latitudes (Crocchianti et al., 2021; Groot Zwaafting et al., 2016, 2017; Meinander et al., 2021; Moroni et al., 2018; Varga et al., 2021), where local HLD dust emissions are increasingly being recognized as a driver for local climate, bio productivity and air quality.

First modelling studies show that main transport pathways from HLD sources are clearly affecting both the High Arctic and the European mainland (Baddock et al., 2017; Beckett et al., 2017; Djordjevic et al., 2019; Groot Zwaafting et al., 2016, 2017; Moroni et al., 2018). HLD can have different physical, chemical, and optical properties compared to typical low latitude mineral dust from, for example, the Sahara or American deserts (Arnalds et al., 2016; Bachelder et al., 2020; Baldo et al., 
75 2020; Crucius, 2021). Some HLD particles are highly light absorbing, especially those of volcanic origin, and can induce significant direct effects on solar radiation fluxes as short-lived climate forcers (SLCF) and on snow optical characteristics (e.g., Peltoniemi et al., 2015), strongly impacting Arctic amplification and cryosphere melt via radiative feedbacks (Boy et al., 2019; Dagsson-Waldhauserova and Meinander, 2019, 2020; IPCC, 2019; Kylling et al., 2018). In addition, dust aerosol can have significant effects on weather and air quality, marine life, and human health, and has significant effects on the formation and properties of clouds (Murray et al., 2021; Sanchez-Marroquin et al., 2020).

Dust produced in high latitude and cold climate environments (Iceland, Greenland, Svalbard, Alaska, Canada, Antarctica, New Zealand, and Patagonia) can have regional and global significance (Bullard et al., 2016). General lack of both observational and modelling studies results in poor HLD monitoring and predicting. Bullard et al. (2016) summarized natural HLD sources to cover over $500000 \mathrm{~km}^{2}$ and to produce particulate matter of ca. $100 \mathrm{Mt}$ dust per year.

The World Meteorological Organization Sand and Dust Storm Warning Advisory and Assessment System (WMO SDS-WAS) monitors and predicts dust storms from the major world deserts (https://www.wmo.int/sdswas), where HLD sources have recently been included in the SDS-WAS dust forecasts. The largest desert in Europe is located at high latitude in Iceland (Arnalds et al., 2016), with dust transport observed over the North Atlantic to European countries (Beckett et al., 2017; Djordjevic et al., 2019; Ovadnevaite et al., 2009; Prospero et al., 2012).

HLD is a short-lived climate forcer, air pollutant and nutrient source, showing the need to identify the geographical extent and dust activity of the HLD sources. Previously, Bullard et al. (2016) designed the first HLD map based on visibility and dust observations, combined with field and satellite observations of high-latitude dust storms, resulting in 129 locations described in 39 papers. Here, we compile together and describe sixty-four HLD sources in the northern and southern high latitudes. Our objectives are to:

(i) identify new previously unpublished HLD sources and describe their characteristics, and include HLD sources identified in recent literature from 2017-2021, which have not been part of previously published collections of HLD sources, in addition to updating some of the previously documented sources

(ii) estimate the high latitude land area with potential dust activity and calculate the source intensity (SI) for the identified sources

(iii) specify key climatic and environmental impacts of HLD, and related research questions, which could improve our understanding on HLD sources in the future.

Our focus is on high latitudes with natural dust sources. We also include some anthropogenic dust sources, for example road dust, when unpaved roads serve as a notable source of dust. Direct emissions of volcanic eruptions and road dust formed via abrasion and wear of pavement or traction control materials are excluded. 


\section{Materials and methods}

\section{$110 \quad 2.1$ Identification and characteristics of dust sources}

To identify, describe and assess new high latitude dust sources at $\geq 50^{\circ} \mathrm{N}$ and $\geq 40^{\circ} \mathrm{S}$ (including Arctic as a subregion at $\geq 60$ ${ }^{\circ} \mathrm{N}$ ), three topical workshops, in Russia, Finland and Iceland (Meinander et al., 2019a,b) on HLD were organized in 2019. The HLD source map and observations on dust properties provided here are based on: i) field and satellite observations not described previously in published academic papers; ii) newly identified HLD source locations reported in academic literature

115 but not included in the previous collections; and iii) new updated observations on some previously documented sources. Each location was assessed to provide a classification for each source, where category 1 refers to an active dust source with high environmental or climatic significance, category 2 to semi-active source with moderate environmental or climatic significance, and category 3 to new sources with unknown activity and significance. Moreover, SI values for each HLD location in the Northern and Southern (Antarctica and Patagonia) high latitudes were quantified and the potential land surface area for dust emissions in north, Arctic and south HLD regions were calculated (Section 2.2). Finally, HLD sources data were used for regional-scale modelling of dust atmospheric transport (Section 6).

\subsection{High latitude dust sources from UNCCD G-SDS-SBM}

The Global Sand and Dust Storms Source Base Map (G-SDS-SBM) developed by the UNCCD in collaboration with the UNEP and the World Meteorological Organization (WMO) (https://maps.unccd.int/sds/; Vukovic, 2019, 2021) represents gridded values of SDS source intensity (SI, values 0 to 1) on resolution of 30 arcsec. It was developed by including the information on soil texture, bare land fraction, using MODIS EVI and land cover data, and topsoil moisture and temperature. Values of SI represent the potential of topsoil to emit soil particles under windy conditions, assigning the highest values of source intensity to best productive surfaces. SI values are derived under the assumption that they are exposed to the same velocity of surface wind. Input data which change depending on the weather (and possibly human activities) for base land fraction, and moisture

130 and temperature data, are defined for four months (January, April, July, October, each month representative for one season) by using extreme values, observed during the period 2014-2018, which provide favorable conditions for surfaces to act as sources. In this way, sources that may appear during the heat waves and during the drier conditions (or drought), when surface in high latitudes is unfrozen, snow-free, and more susceptible to wind erosion, are included in this map. Such weather extremes under climate change are becoming more frequent and projected to increase (IPCC, 2013), which justifies the source mapping

135 approach using information on extreme topsoil conditions. Using the maps produced for four seasons, maximum and minimum values are determined for each grid point to explore potential of high latitude land surfaces to act as dust sources, their seasonality, and to compare values of source intensity with marked locations of HLD sources. 


\section{Geographic locations of the HLD sources}

Sixty-four HLD sources at northern and southern high latitudes (Fig. 1) were identified. In the north HLD region, there are 49

140 locations in Alaska, Canada, Denmark, Greenland, Iceland, Svalbard, Sweden, and Russia. From these, 35 locations are in the Arctic HLD subregion. In the south HLD region, there are 15 identified sources, situated in Antarctica and in Patagonia, South America. The sources included Arctic and Antarctic, boreal, remote, rural, urban, mountain, marine and coastal, river sediments, mining, and road dust, as well as weathered surface and glacial floodplain of soils (Podzols, Retisols, Gleysols, Phaeozems, Stagnosols), and glacial dust. The observational periods for these locations varied from days or weeks to multiple

145 years, and included data from ground-based measurements, remote sensing data, and modelling results. Results on the calculated source intensity and areas of high latitude surface land with higher ( $\mathrm{SI} \geq 0.5)$, very high $(\mathrm{SI} \geq 0.7)$ and the highest potential ( $\mathrm{SI} \geq 0.9$ ) for dust emission are presented in Section 4. Observations and characteristics of the identified dust sources in our collection (Fig.1) are presented in Section 5 and in in the Supplement Tables S1-S8 (including the contemporary classification for each source into categories 1-3, based on the currently available observations, in Table S1; satellite observations on new HLD sources in Iceland in Table S2, observations on new HLD sources in Greenland and Canada in Table S3; SI values in Tables S4 and S5, and results from Russian HLD sources in S6-S8). 


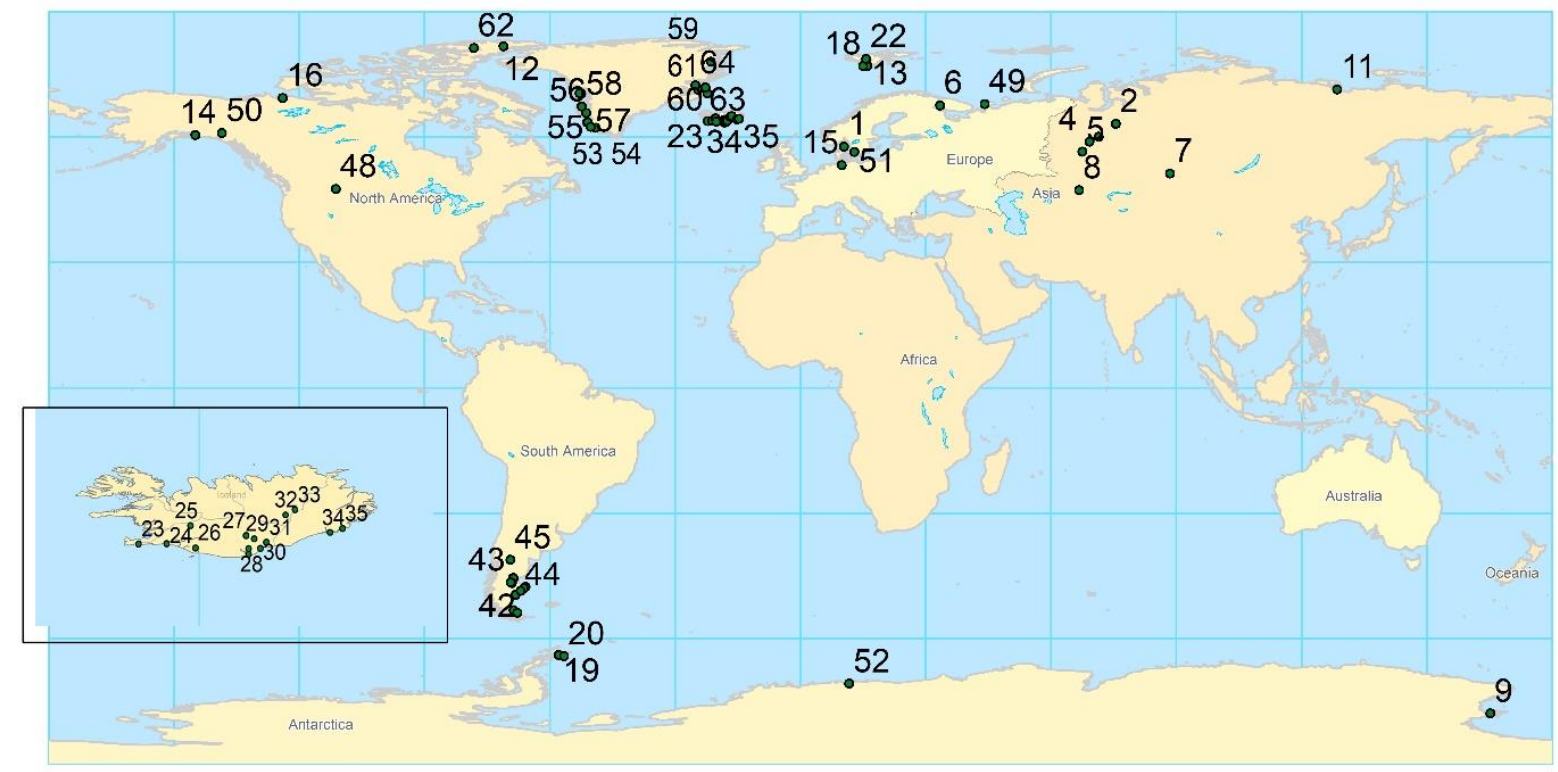

Figure 1. Map of the geographic locations of the northern (north of $50{ }^{\circ} \mathrm{N}$, including Arctic $\geq 60{ }^{\circ} \mathrm{N}$ ) and southern (south of $40{ }^{\circ} \mathrm{S}$ ) high latitude dust (HLD) sources identified and included in this study.

\section{Source intensity from UNCCD G-SDS-SBM}

The G-SDS-SBM source intensity values (maximum and minimum) for the north HLD region are presented in Figure 2. The north HLD region also includes the area north of latitude $50^{\circ} \mathrm{N}$, and the Arctic region as a subregion of HLD region as north of $60{ }^{\circ} \mathrm{N}$. HLD dust sources show extreme seasonal character, with some exceptions. The sources appear and disappear (or change SI values) seasonally or appear (or increase source intensity values) only during the favorable extreme weather conditions. Figure 3 shows G-SDS-SBM source intensities values for south HLD region (south of $40{ }^{\circ} \mathrm{S}$ ), without values for Antarctica, since G-SDS-SBM does not include areas south of $60{ }^{\circ} \mathrm{S}$. In the Supplementary Table S4 and S5 give the values of SI for specific locations marked in Figure 1. 

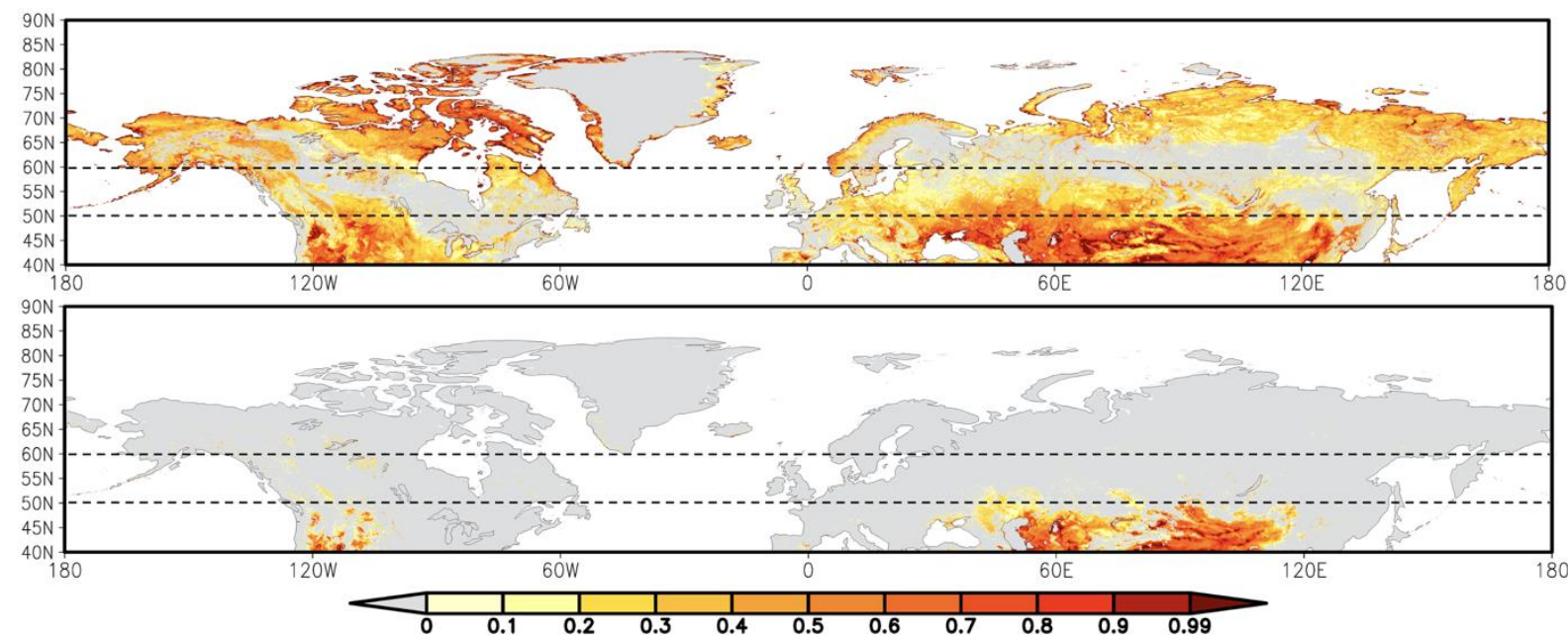

Figure 2. UNCCD Global Sand and Dust Storms Source Base Map (G-SDS-SBM) for annual maximum (upper panel) and minimum (lower panel) source intensity, for north HLD region and Arctic sub-region (north of $50^{\circ} \mathrm{N}$ and $60^{\circ} \mathrm{N}$, respectively, marked with dashed lines).

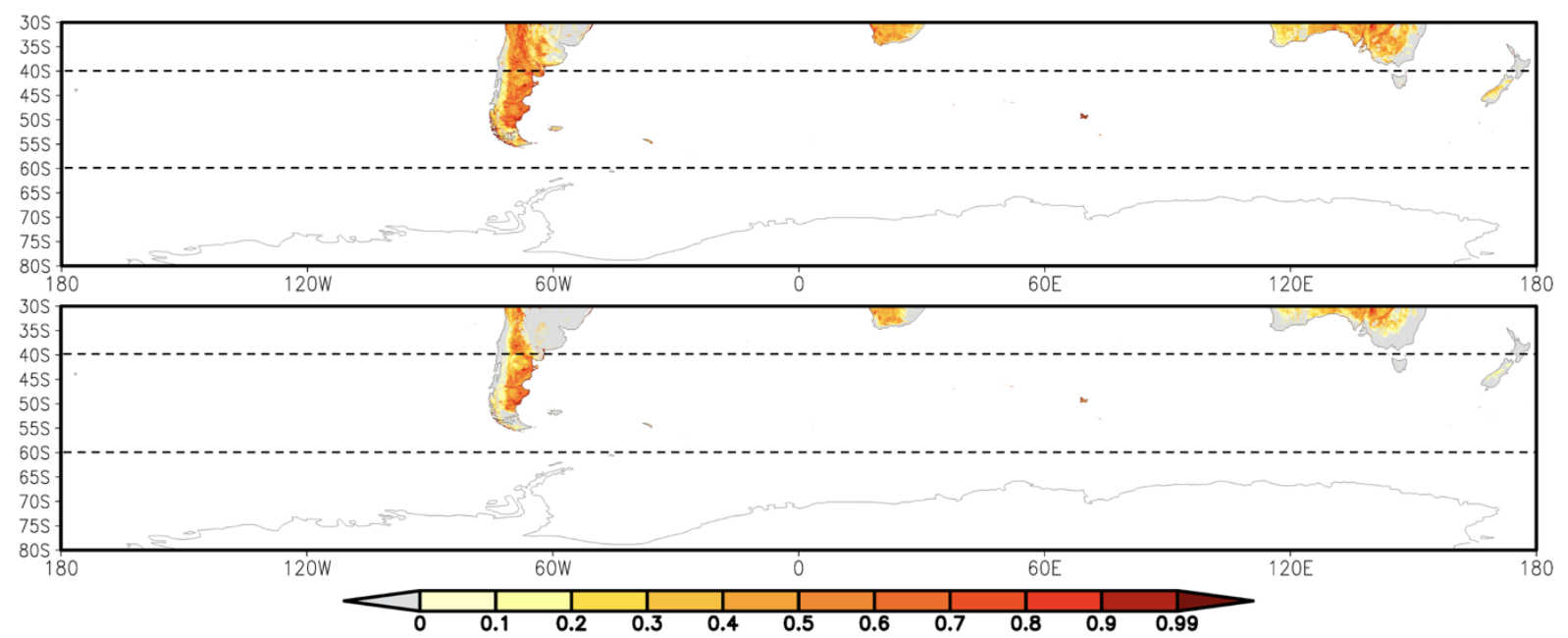

175

Figure 3. UNCCD Global Sand and Dust Storms Source Base Map (G-SDS-SBM) for annual maximum (upper panel) and minimum (lower panel) source intensity, for south HLD region (south of $40^{\circ} \mathrm{S}$ ) without Antarctica (area south of $\left.60^{\circ} \mathrm{S}\right)$, marked with dashed lines.

Total surface area of dust sources with higher potential for dust emission ( $\mathrm{SI} \geq 0.5$ ) over north HLD region (north of $50{ }^{\circ} \mathrm{N}$ ) is $3.9 \%$ of total land surface or $1364799 \mathrm{~km}^{2}$, the area with very high potential for dust emission (SI $\left.\geq 0.7\right)$ is $1.5 \%$ or 509965 $\mathrm{km}^{2}$, and the area with highest dust emission potential ( $\left.\mathrm{SI} \geq 0.9\right)$ is $0.7 \%$ of total land area or $233336 \mathrm{~km}^{2}(\mathrm{Table} 1)$. In the 
Arctic region (north of $60^{\circ} \mathrm{N}$ ), the subregion of north HLD area, dust sources with higher potential for dust emission (SI $\geq 0.5$ )

is $5.5 \%$ of total land surface or $1035059 \mathrm{~km}^{2}$, the area with very high potential for dust emission (SI $\left.\geq 0.7\right)$ is $2.3 \%$ or 440 $804 \mathrm{~km}^{2}$, and the area with the highest dust emission potential $(\mathrm{SI} \geq 0.9)$ is $1.1 \%$ or $208701 \mathrm{~km}^{2}$. Minimum values dust productive surface areas in the north HLD region are about three orders of magnitude smaller than the maximum, meaning that the north HLD dust sources are highly dependable on weather conditions. Maximum surfaces comprehend dust productive areas that are defined under the most favorable weather conditions for soil exposure to wind erosion (including extreme weather). All sources defined here are not necessarily active every year, nor in the same period, meaning that these surfaces can be seasonally or occasionally (under extreme weather) appearing as dust sources.

For the south HLD region $\left(40^{\circ} \mathrm{S}-60^{\circ} \mathrm{S}\right.$, area without Antarctica), the land surface is only $2 \%$ of the total area surface (Table 2). The surface area of dust sources with $\mathrm{SI} \geq 0.5$ is $22.6 \%$ of the total land surface or $309520 \mathrm{~km}^{2}$, the area with $\mathrm{SI} \geq 0.7$ is

$1954.5 \%$ or $61527 \mathrm{~km}^{2}$, and the area with highest dust emission potential $(\mathrm{SI} \geq 0.9)$ is $0.6 \%$ or $8630 \mathrm{~km}^{2}$. The surface areas for minimum SI values above these thresholds are two to three times smaller from the surfaces for maximum SI values compared to the difference in the north HLD region. This means that soil surface conditions in south HLD region are favorable for dust emission during the whole year. Especially, in locations of HLD markers, SI maximum and minimum values do not change over majority of locations or decrease by 0.1 or 0.2 , with exception of only one location (no. 38), which has SI values changing from 0.9 to 0 at location of HLD marker.

Table 1. Relevant surfaces for the north HLD region and the Arctic region: total surface of the region, surface of land within the region (in $\mathrm{km}^{2}$ and \% of total surface), total surface (in $\mathrm{km}^{2}$ and \% of land surface) of areas with SI values above thresholds in maximum and minimum seasonal values; values are derived from UNCCD G-SDS-SBM.

NORTH HLD REGION (NORTH OF 50 ${ }^{\circ}$ )

\begin{tabular}{|c|c|c|c|c|}
\hline \multirow{2}{*}{\multicolumn{2}{|c|}{$\begin{array}{c}\text { total }\left(\mathbf{k m}^{2}\right) \\
64392015 \\
\end{array}$}} & \multirow{2}{*}{$\begin{array}{c}\text { land }\left(\mathbf{k m}^{\mathbf{2}}\right) \\
34695710 \\
\end{array}$} & \multirow{2}{*}{\multicolumn{2}{|c|}{$\begin{array}{c}\text { land }(\%) \\
54 \\
\end{array}$}} \\
\hline & & & & \\
\hline & \multicolumn{2}{|c|}{$\max$} & \multicolumn{2}{|c|}{$\min$} \\
\hline & $S\left(\mathbf{k m}^{2}\right)$ & $\mathrm{S}(\%)$ & $S\left(\mathbf{k m}^{2}\right)$ & S (\%) \\
\hline $\mathrm{SI} \geq 0.5$ & 1364799 & 3.9 & 1916 & 0.006 \\
\hline $\mathrm{SI} \geq 0.6$ & 803372 & 2.3 & 1053 & 0.003 \\
\hline $\mathrm{SI} \geq 0.7$ & 509965 & 1.5 & 718 & 0.002 \\
\hline $\mathrm{SI} \geq 0.8$ & 342913 & 1.0 & 562 & 0.002 \\
\hline SI $\geq 0.9$ & 233336 & 0.7 & 451 & 0.001 \\
\hline
\end{tabular}

ARCTIC REGION (NORTH OF $60^{\circ}$ N)

total $\left(\mathbf{k m}^{2}\right)$

land $\left(\mathbf{k m}^{2}\right)$ land $(\%)$ 


\begin{tabular}{|c|c|c|c|c|}
\hline & \multicolumn{2}{|c|}{18853826} & \multicolumn{2}{|c|}{51} \\
\hline & \multicolumn{2}{|c|}{$\max$} & \multicolumn{2}{|c|}{$\min$} \\
\hline & $S\left(\mathbf{k m}^{2}\right)$ & S (\%) & $\mathrm{S}\left(\mathrm{km}^{2}\right)$ & S (\%) \\
\hline $\mathrm{SI} \geq 0.5$ & 1035059 & 5.5 & 515 & 0.003 \\
\hline $\mathrm{SI} \geq 0.6$ & 665082 & 3.5 & 350 & 0.002 \\
\hline $\mathrm{SI} \geq 0.7$ & 440804 & 2.3 & 297 & 0.002 \\
\hline $\mathrm{SI} \geq 0.8$ & 303521 & 1.6 & 264 & 0.001 \\
\hline $\mathrm{SI} \geq 0.9$ & 208701 & 1.1 & 217 & 0.001 \\
\hline
\end{tabular}

Table 2. Relevant surfaces for the south HLD region: total surface of the region, surface of land within the region (in $\mathrm{km}^{2}$ and $\%$ of total surface), total surface (in $\mathrm{km}^{2}$ and \% of land surface) of areas with SI values above thresholds in maximum and minimum seasonal values; values are derived from UNCCD G-SDS-SBM.

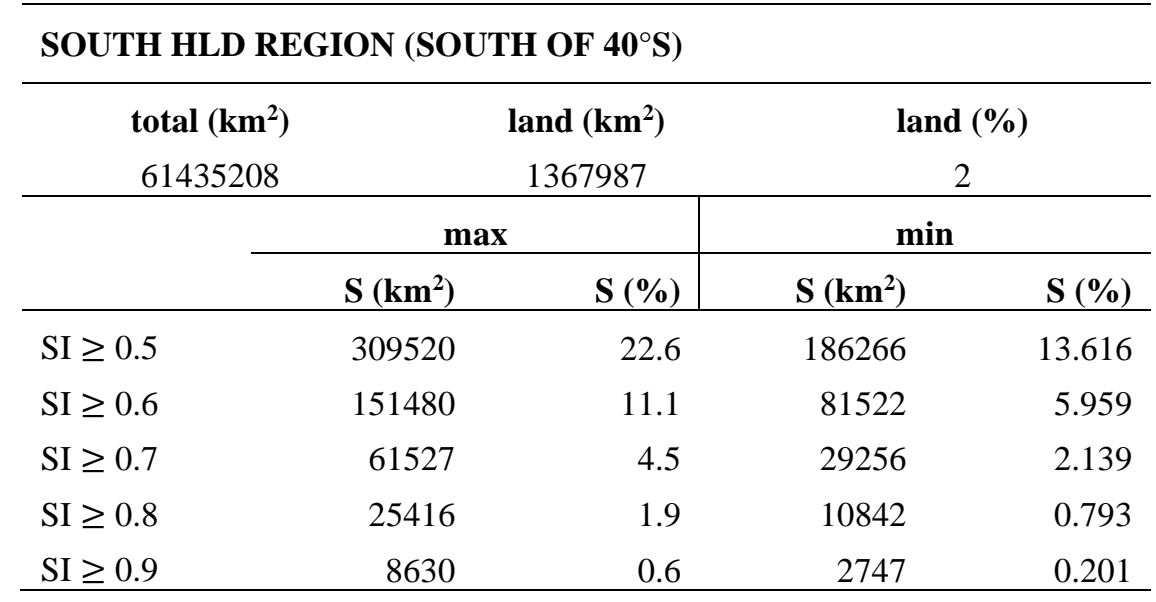

\section{Observations and characteristics of the identified regional dust sources}

215 Observations and characteristics of the identified sixty-four dust sources in our collection (Figure 1) are presented and discussed here in alphabetical order as: 1. Alaska, 2. Antarctica, 3. Canada, 4. Denmark and Sweden, 5. Greenland, 6. Iceland, 7. Russia, 8. South America and Patagonia, and 9. Svalbard.

\subsection{Alaska, Copper River Valley, USA}

Alaskan dust sources were identified more than a century ago (Tarr and Martin, 1913), but limited satellite detection due to abundant cloud cover and isolated location resulted in sparse information on this region (Crusius et al, 2011). The main identified sources are piedmont glaciers (Malaspina, Bering), resuspension of ash from past eruptions (Hadley et al., 2004) and glacial sediment carrying major rivers (Copper, Yukon, Tanana, and Alsek) (Gassó, 2021a,b; 2020a,b). Resuspension of glacial dust transported by these rivers can be abundant, and often triggers air quality alerts by the Alaska Department of 
Environment (USGCRP, 2018). The largest and most active of such dust sources is the Copper River, which is estimated to

transport 69 million tons of suspended sediment per year (Brabets, 1997). Transported sediment is deposited on the Copper River Delta, an alluvial floodplain covering an area of $2800 \mathrm{~km}^{2}$, and, when conditions allow, is resuspended resulting in dust plumes which can extend hundreds of kilometers over the Gulf of Alaska. Dust events, which often last several days or weeks (Schroth et al., 2017), are most common in late summer and autumn when the river discharge and snow cover are at their minimum and high wind speeds are common (Cruisius, 2021), however they have been observed throughout the year (Gassó, 2021a, in Jan 2021). Because dust reaches the open waters beyond the continental shelf and the influence of coastal sediments (Crusius et al, 2017), it has been proposed that dust from coastal sources such as the Copper River Delta can be an important source of bioavailable iron in the Gulf of Alaska (Crusius et al., 2011, 2021; Schroth et al., 2017). Further work is also needed to investigate the relative importance of dust emissions from Alaska and from East Asia (Bishop et al., 2002) in other areas. In addition, dust from this region may initiate ice production in supercooled clouds that are important for climate feedbacks (Murray et al., 2021). With regards to the magnitude and seasonal variability of emissions of sources in southern Alaska, there have been a few dedicated studies focusing on dust from Copper River delta (Crusius, 2021; Crusius, et al., 2017; Schroth et $\mathrm{al}$, 2017) however, to our knowledge, no dust activity and source characterization has been carried out along the coast of the Gulf of Alaska. In addition, resuspended road dust is a major air quality issue locally throughout Alaska.
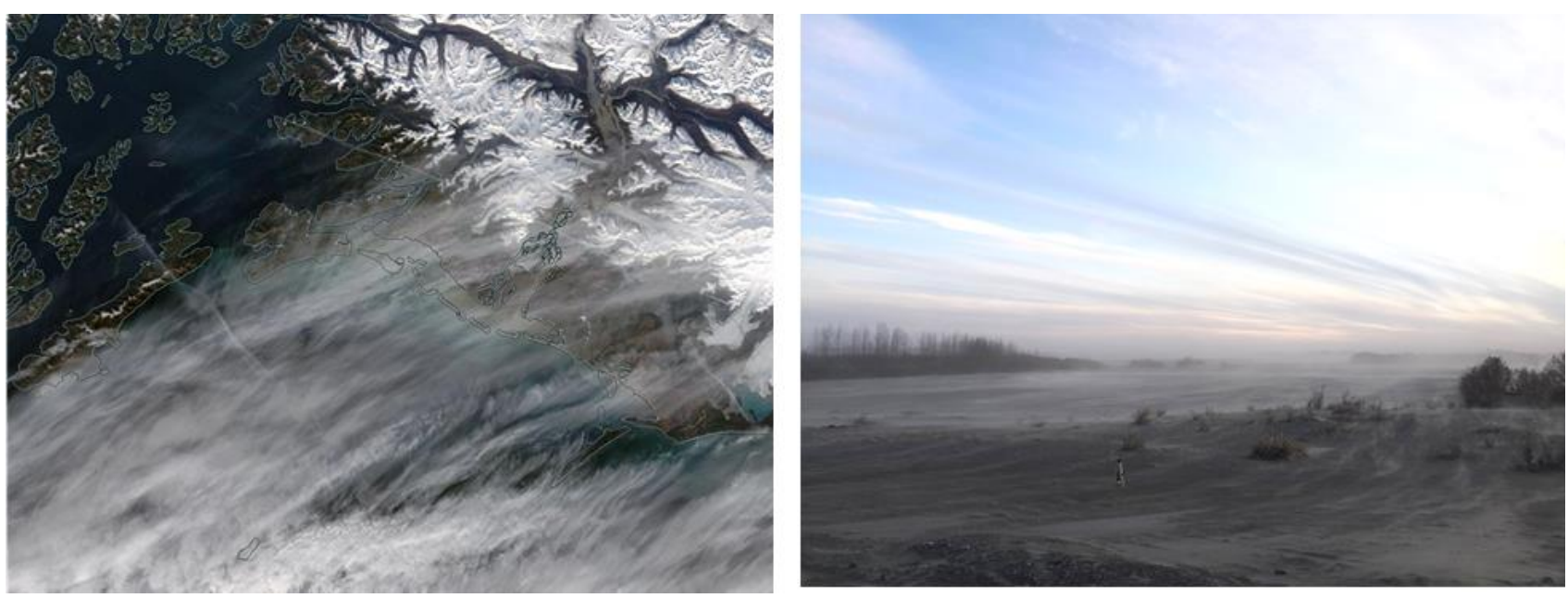

Figure 4. Satellite image (left) of the Copper River region and photo (right) taken at the Copper River delta on the same day (14th October 2019). The common occurrence of clouds prevents the direct view of dust in suspension illustrating the difficulty in observing dust activity from space. (Photo by Sarah Barr, satellite image from NASA Worldview). 


\subsection{Antarctica}

\subsubsection{James Ross Island, Ulu Peninsula}

The northern part of James Ross Island - Ulu Peninsula - represents one of the largest ice-free areas of Antarctica $\left(312 \mathrm{~km}^{2}\right)$. Its bare surface consisting mainly of weathered sedimentary rocks is an active HLD source (Kavan et al., 2017, 2018). Suspended sediments originate from outside the local fluvial systems based on the elemental ratios of $\mathrm{Sr} / \mathrm{Ca}$ and $\mathrm{Rb} / \mathrm{Sr}$. The wind speed threshold of $10 \mathrm{~ms}^{-1}$ is needed for activating local dust sources with the majority of the particles captured (by mass) in size bins between 2.5-10 $\mu \mathrm{m}$. Mean (median) mass concentrations of the PM10 were $6.4 \pm 1.4(3.9 \pm 1) \mu \mathrm{g} \mathrm{m}{ }^{-3}$, while the PM2.5 was $3.1 \pm 1(2.3 \pm 0.9) \mu \mathrm{g} \mathrm{m}^{-3}$ for the whole measurement period in January-March 2018. Mean PM10 values are comparable to background stations in Northern Europe. The highest daily aerosol concentration was $57 \mu \mathrm{g} \mathrm{m}^{-3}$ for PM10 with hourly PM10 with > $100 \mu \mathrm{g} \mathrm{m}^{-3}$. Higher aerosol concentration occurs in late austral summer when soil water content in the upper soil layer is significantly lower in comparison to the early summer season. Long-range transport of dust originating in Patagonia was observed during aerosol measurements (Kavan et al., 2018). Higher proportion of long range transported dust was found in snow pits on higher elevated glaciers compared to higher proportion of locally transported dust in lower elevated glaciers (Kavan et al., 2020b). Kňažková et al. (2020) identified redistribution of mineral material within the HLD source area in Abernethy Flats impacting the local microtopography.

\subsubsection{Marambio, Antarctic Peninsula}

The Marambio Base (64.241014S, 56.626753W) on Marambio Island, Graham Land, Antarctic Peninsula, is a member of the

Global Atmosphere Watch (GAW) programme of the WMO and has personnel available year-round. This region has ice-free areas and cold desert soils (Cryosols) that can be seasonally susceptible to wind erosion and weathering; the removal of fine materials takes place mainly by wind action. The Finnish-Argentinian co-operative research in Marambio includes measurements on ozone, solar irradiance, aerosols, and ultraviolet (UV) albedo (e.g., Aun et al., 2020). The UV Biometer Model 501 from Solar Light Co. (SL501) UV albedo data of 2013-2017 in Marambio, were used to analyze the effects of local HLD on measured snow UV albedo and solar UV irradiance and on differences in simulated UV irradiances (Meinander et al., 2018). For validation of the UV albedo data, surface photos were taken on a regular basis. The surface photos and UV albedo measurements show that local dust can be detected on the top of snow and ice. These findings suggest that in Marambio local dust can decrease surface snow/ice albedo and possibly enhance, due to the ice-albedo feedback mechanism, the cryosphere melt, and contribute to warming, in the Antarctic Peninsula.

\section{5.2.3. McMurdo Sound, Antarctica}

The McMurdo Sound area of the Ross Sea region is widely recognised as the dustiest place in Antarctica, where locally sourced aeolian accumulation is up to two to three orders of magnitude above global background and dust fallout rates for the continent 
(Chewings et al., 2014; Winton et al., 2014). The area includes the McMurdo Dry Valleys (MDV) which is the largest ice-free area $\left(4800 \mathrm{~km}^{2}\right)$ in Antarctica. The MDV has high, but extremely variable fluxes of locally derived aeolian sand (e.g. Speirs et al., 2008; Lancaster et al., 2010; Gillies et al 2013; Diaz et al., 2020) and common aeolian landforms which has led to the assumption that the MDV is a significant regional dust source (e.g. Bullard, 2016), with some modelling studies suggesting that the MDV could supply large volumes of dust to a wide area of the Southern Ocean (e.g. Bhattachan et al., 2015). However, field-based observations show that very little sediment is transported out of the MDV (Ayling and McGowan, 2006; Atkins and Dunbar 2009; Chewings et al., 2014; Murray et al., 2013) because the valleys have already been extensively winnowed into a well-developed deflation surface and large coastal piedmont glaciers form a topographic barrier preventing aeolian sediment escaping. The dominant source of aeolian sediment in the McMurdo Sound area is the debris covered surface of the McMurdo Ice Shelf $\left(1500 \mathrm{~km}^{2}\right)$ with minor contributions from local ice-free headlands. This iceshelf is unusual in that it has high surface ablation and continuously replenished supply of fine-grained sediment advected from the seafloor. The sediment is blown off the iceshelf by frequent southerly strong wind events forming a visible sediment plume out onto coastal sea ice. Within a few $\mathrm{km}$ of the ice shelf, accumulation rates on sea ice are up to $55 \mathrm{~g} \mathrm{~m}^{-2} \mathrm{yr}^{-1}$, reducing rapidly downwind to an average of $1.14 \mathrm{~g} \mathrm{~m}^{-2} \mathrm{yr}^{-1}$, equating to $0.6 \mathrm{kt} \mathrm{yr}^{-1}$ of aeolian sediment entering McMurdo Sound each year (Atkins and Dunbar, 2009; Chewings et al., 2014). Some sediment is transported at least $120 \mathrm{~km}$ from source and could potentially travel much farther, contributing iron-rich dust to the Ross Sea (Winton et al., 2014). Coastal areas and lowland parts of the MDV are on the threshold of climatically driven change with observed increases in ablation and seasonal meltwater flow incising into permafrost (Fountain et al., 2014) suggesting that dust potential of McMurdo Sound and the MDV could change rapidly in the future. McMurdo Dry Valley $\left(4800 \mathrm{~km}^{2}\right)$ is here estimated to best fit to Category 3 (source with unknown activity, Table S1). The McMurdo Ice shelf 'debris bands' are estimated here to best fit to Category 2 (moderately active source).

\subsubsection{Shirmacher oasis, East Antarctica}

The Schirmacher oasis $\left(70^{\circ} 45^{\prime} 30^{\prime \prime} \mathrm{S}, 11^{\circ} 38^{\prime} 40^{\prime \prime} \mathrm{E}\right)$ is located approximately in $80 \mathrm{~km}$ from the coast of Lazarev Sea, Queen Maud Land, East Antarctica. The oasis is ice free area of over $35 \mathrm{~km}^{2}$ with typically hillocky relief. The oasis and surrounding area have been explored since early 1960s, and recently the oasis shelters four polar camps operated seasonally or year roundly. There are no systematic studies on dust on local ice and snow. Snow samples were collected in December 2019 on 11 sites in the oasis, and in a vicinity of the local ice roads (data unpublished). Most of the dust in this region is assumed to be formed with the soils blown in the air because of strong winds. The anthropogenic dust due to human activity is also contributing to this region because there are the seasonal and year-round operated bases which use the petrol to heat supply. Snow cover in the vicinity of the bases has been observed to be dirtier than far from them. 


\subsection{Canada}

\subsubsection{Lake Hazen, Ellesmere Island}

Satellite observations of high latitude dust events over water are relatively common (see, for example, Bullard et al., 2016) the

detection of such events, whether directly in terms of explicit plume remote sensing or indirectly in terms of plume deposition has remained largely unreported. Ranjbar et al. (2020) recently reported the detection of a drainage-flow induced dust plume over (frozen) Lake Hazen, Nunavut, Canada using a variety of remote sensing techniques (Lake Hazen is the Arctic's largest lake, by volume, at $81.8{ }^{\circ} \mathrm{N}$ latitude in the northernmost portion of Ellesmere Island). Figure 5 shows a true-color georeferenced, RGB MODIS-Terra image acquired on 19 May 2014 at 19:50 UT (15:50 EDT) over Lake Hazen. The authors employed MISR stereoscopy, CALIOP and CloudSat vertical profiling, as well as MODIS thermal IR techniques to identify and characterize the plume as it crossed over a complex springtime terrain of snow, ice and embedded dust. The plume characterization, while limited by the lack of dedicated dust remote sensing algorithms over snow and ice terrain, boded well for the development of systematic, satellite-based, high-latitude dust detection approaches using current and future generations of aerosol and cloud remote sensing platforms.

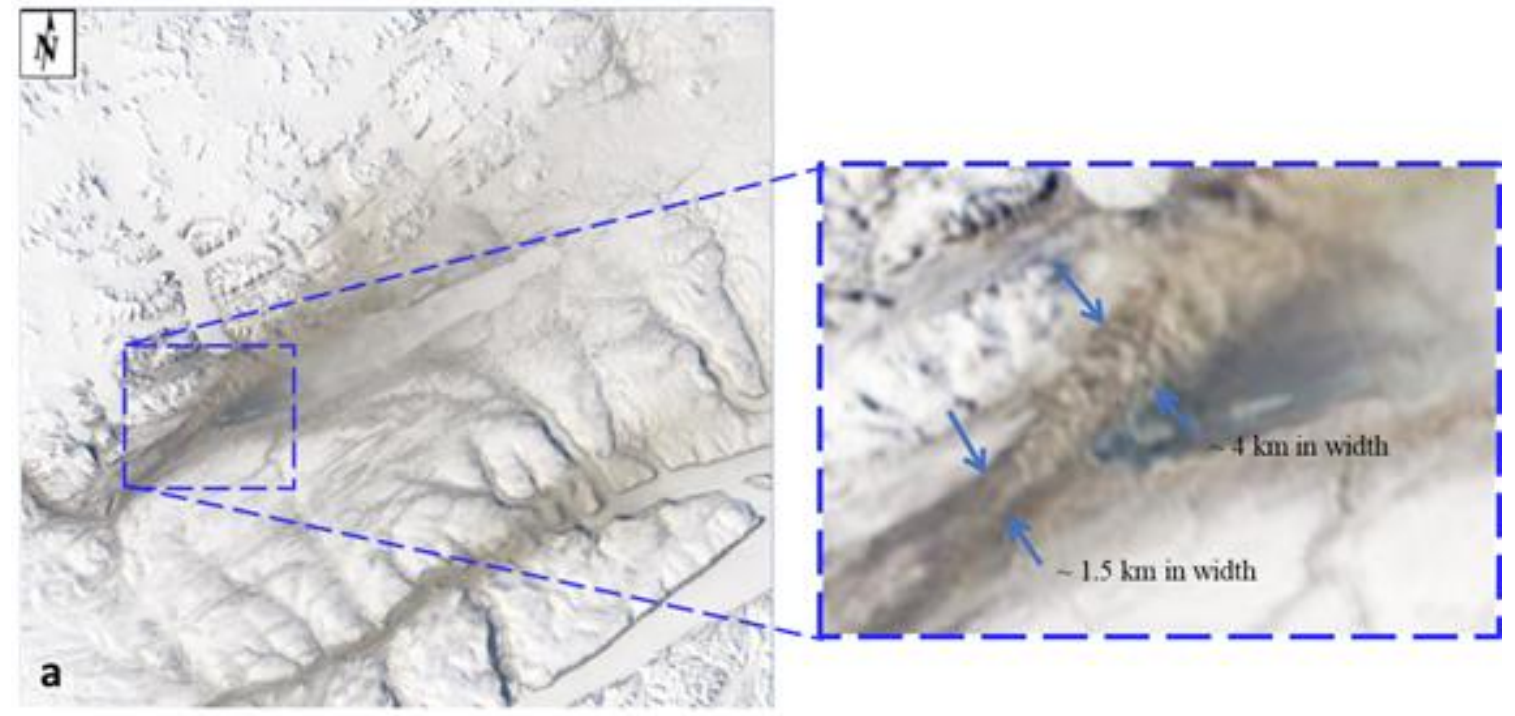

Figure 5. MODIS-Terra satellite image on 19 May, 2014 19:50 UTC (a) True color image: MODIS channels 1 (620-670nm), 3 (459$479 \mathrm{~nm})$ and $4(545-565 \mathrm{~nm})$ were loaded into the RGB channels of the display. The sub-image is a zoom of the most discernible part of the plume (outlined by the blue broken-line square). 


\subsubsection{Canada, Kluane Lake, Yukon}

Within the St. Elias Mountain range at the north end of the Pacific Coast Range on the continental side within the Yukon Territory lies the Kluane Lake region (KLR) that contains Łhù'ààn Mân' (Kluane Lake) (location no. 50 in Fig.1). The lake itself is fed primarily from the meltwater of the Kaskawulsh glacier down the A'äy Chù (formally the Slims River) in addition to snowmelt from the surrounding regions in the springtime. This seasonal discharge has in recent history known to be highly variable as the glacier terminates at the fork of two distinct watersheds, one draining into the Bering Strait through the Yukon River and the other into the Gulf of Alaska, supplying the two watersheds inconstant ratios. In 2016, the majority of discharge of the glacier was diverted to the Gulf of Alaska in an intense discharge event dramatically decreasing the Łhù'àn Mân water levels and increasing the dust emission potential from the A'äy Chù (Shugar et al., 2017). This drastic change makes the KLR an excellent natural laboratory for investigating the impact of pro-glacial hydrology on dust emission potential under past and future climates. Research was conducted in the early 1970s in this same valley as a comprehensive set of dust flux measurements as part of several publications (Nickling, 1978; Nickling and Brazel, 1985). Nickling (1978) concluded that there is a dynamic relationship between soil moisture (driven by precipitation and night time radiation insolation) and wind resulting in a periodicity of dust emissions from the valley in all but the mornings throughout the snow free seasons. Within a more recent study by Bachelder et al. (2020), soil and aerosol samples were collected within the Ä'äy Chù delta, where air quality thresholds were exceeded, indicating a negative impact on local air quality throughout the month of May. Notably, daily particle size distributions of PM10 were very fine (mode of $3.25 \mu \mathrm{m}$ ) as compared to those measured at more wellcharacterized, low-latitude dust sources. In addition, mineralogy and elemental composition of ambient PM10 were found to be enriched in trace elements (e.g., As and $\mathrm{Pb}$ ) as compared to dust deposition, bulk soil samples, and the fine soil fractions (d $345<53 \mu \mathrm{m})$. Finally, through a comparison of the elemental composition of PM10, dust deposition, and both fine and bulk soil fractions, as well as of meteorological factors measured, Bachelder et al. (2020) propose that the primary mechanisms for dust emissions from the Ä'äy Chù are the rupture of clay coatings on particles and/or the release of resident fine particulate matter.

\subsection{Denmark and Sweden}

In Denmark, large areas with severe wind erosion have been documented in the past (Kuhlman, 1960). Published literature on activity of dust sources in Denmark is rare, and some documentation is in Danish only. On 23 April 2019, a dust plume from Denmark west coast, together with dust plumes from Sweden from $12 \mathrm{~km}$ long Mellbystrand around the mouth of the Lagan River (No. 51) and Poland could be observed in Meteosat-11 Dust RGB and Natural Colour images, 23 April 12:30 UTC. These dust plumes were observed to travel to the North Sea (Meteosat, 2019). The source in Denmark appears to be from Holmsland dunes (No. 15). Other potential dust sources in Denmark include, e.g., the Råbjerg mile (No. 1), which is the largest moving dune in Northern Europe with an area of around $2 \mathrm{~km}^{2}$ (Doody, et al. 2014), and located between Skagen and Frederikshav. Råbjerg Mile moves with a speed of approximately 15 meters per year due to wind and has moved around 1.5 $\mathrm{km}$ further east over in the last 110 years. The drifting sand is not considered being transported very far. In general, dust storms 
in Denmark are considered small, and locally based dust storms can be expected when farmers prepare the arable soils in spring creating in case of a very dry April month, when the crops are not up. In Tilviden, flying sand has taken over (after King Frederik II king cut the oak trees for building ships by 1600). In addition, a regional soil and sand event in Denmark, reported common to the region in April, was reported recently between Mejrup and Holtebro on 6 April 2021 (Television Midtvest, 2021; not identified in Fig1; coordinates are estimated to be 56.386, 8.697). This remains to be marked as a potential dust source location for the future observations. The event was observed over roadways in several parts of the region, reducing visibility, due to a long period without rain and strong winds for $>24$ hours, causing the soil to blow off the harrowed fields.

\subsection{Greenland}

The ice-free areas of Greenland have long been identified as locally important dust sources (Hobbs, 1942) with dust storms described as reaching >100 m high (Dijkmans and Törnqvist, 1991) and potentially causing darkening of the Greenland Ice Sheet by deposition, which may affect albedo and rates of ice melt (Wientjes et al., 2011; McCutcheon et al., 2021). Potential dust source areas in Greenland are mapped in the recently issued global dust atlas by A. Vukovic (UNCCD, 2021). Dust input to soils and lakes may also have substantial ecological impacts (Anderson et al., 2017). Bullard and Mockford (2018) investigated the seasonal and decadal variability of dust emissions in southwest Greenland and presented the first long-term assessment of dust emissions. Dust emissions occur all year round but peak in spring and early autumn. The evidence linking increased dust emissions to preceding jökulhlaup (a type of glacial outburst flood) events is somewhat inconclusive and requires further exploration. The decadal record confirmed that dust-storm magnitude may have increased from 1985 to the 1990s (Bullard and Mockford 2018). Amino et al. (2020) also showed that dust deposition on the south easter dome in Greenland has increased in recent decades and they link this to dust emissions in coastal Greenland where snow cover is decreasing. However, further work is needed to characterize the magnitude of dust events at source and how emissions from these sources are changing. Bullard and Mockford also presented preferential dust-event pathways from Kangerlussuaq, indicating that most events travel toward the Davis Strait and the Labrador Sea, where the dust might impact boundary layer mixed phase clouds (Murray et al., 2021).

Modern satellite remote sensing methods are able to detect dust storm events in different valleys and coastal areas of Greenland. The new HLD sources identified in this study based on satellite observations are listed in Supplementary Table S3. Figure 6 illustrates one such dust storm episode on the Nuussuaq Peninsula, Greenland on October 1st, 2020 (Markuse, 2020). One example of DREAM regional-scale modelling of dust atmospheric transport from Greenland potential dust sources is demonstrated in Figure 12, where the DREAM circumpolar prediction experiment example shows (A) dust source map according to the Sand and Dust Storm (SDS) Basemap; (B) Predicted surface dust concentration for 4 November 2013; MODIS vs. model comparison (Model results: Courtesy of G. Pejanovic, RHMSS). 


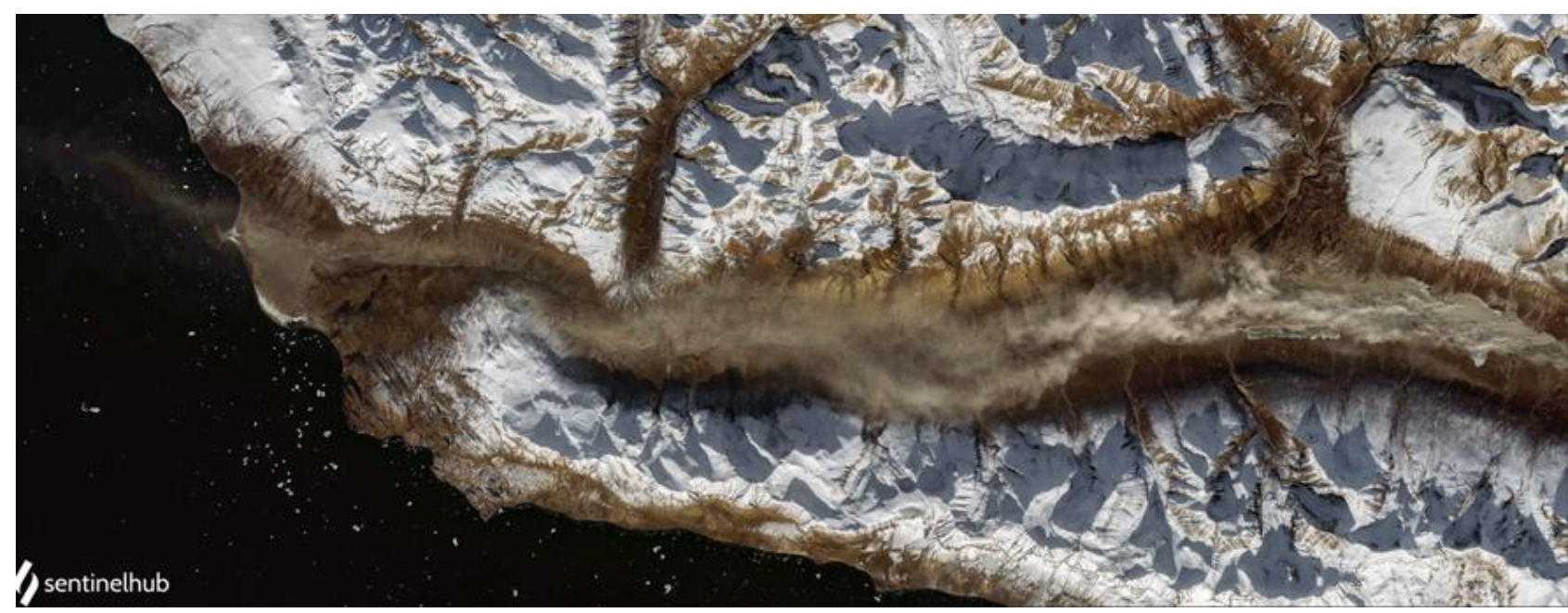

Figure 6. High latitude dust storm on the Nuussuaq Peninsula, Greenland - October 1st, 2020 (Markuse, 2020; cc-by-2.0.2020).

\subsection{Iceland}

Previously, eight dust hot spots have been identified in Iceland (Arnalds et al., 2016). Additionally, Sandkluftavatn,

Kleifarvatn, Skafta jökulhlaup deposits and other areas have been lately found to produce large amounts of dust (DagssonWaldhauserova et al., 2019). In recent years, increased dust activity has been reported also from Flosaskard and Vonaskard (Gunnarsson et al., 2020). These dust hotspots cover almost $500 \mathrm{~km}^{2}$, while deserts are at over $45000 \mathrm{~km}^{2}$ (Arnalds et al., 2016). Most of the dust hotspots are in the vicinity of glaciers and are glacial floodplains, old lakes, jökulhlaup (a type of glacial outburst flood) deposit areas or sandy beaches. Glacio-fluvial plains receive a huge amount of unconsolidated silty material during melting episodes of nearby glacial areas.

New dust sources identified here, with the number of events, are presented based on satellite image observations from 20022011 (Supplementary Table A2). The observations suggest that the entire southern coast of Iceland could be considered as one source. However, previous results on Icelandic dust suggest that nearby locations may have different particle characteristics (Fig. 7) and therefore each source needs to be studied independently. For example, the train size distribution curves of the samples from Dyngjusandur, Hagavatn, Landeyjarsandur, Maelifellsandur, Myrdahlsandur and Sandkluftavatn showed generally unimodal distributions with a rather diverse character (average diameters ranging from 19.8 to $97.7 \mu \mathrm{m}$, Fig. 7). Richards-Thomas et al. (2021) identified a range in particle diameter between $0.4 \mu \mathrm{m}$ and $89 \mu \mathrm{m}$, with the medians (d50) of the distributions from $12-25 \mu \mathrm{m}$ ). Some hotspot particles are bimodal with peaks at $2 \mu \mathrm{m}$ and $30 \mu \mathrm{m}$ and a greater proportion of the sample lying within the silt-size range. 


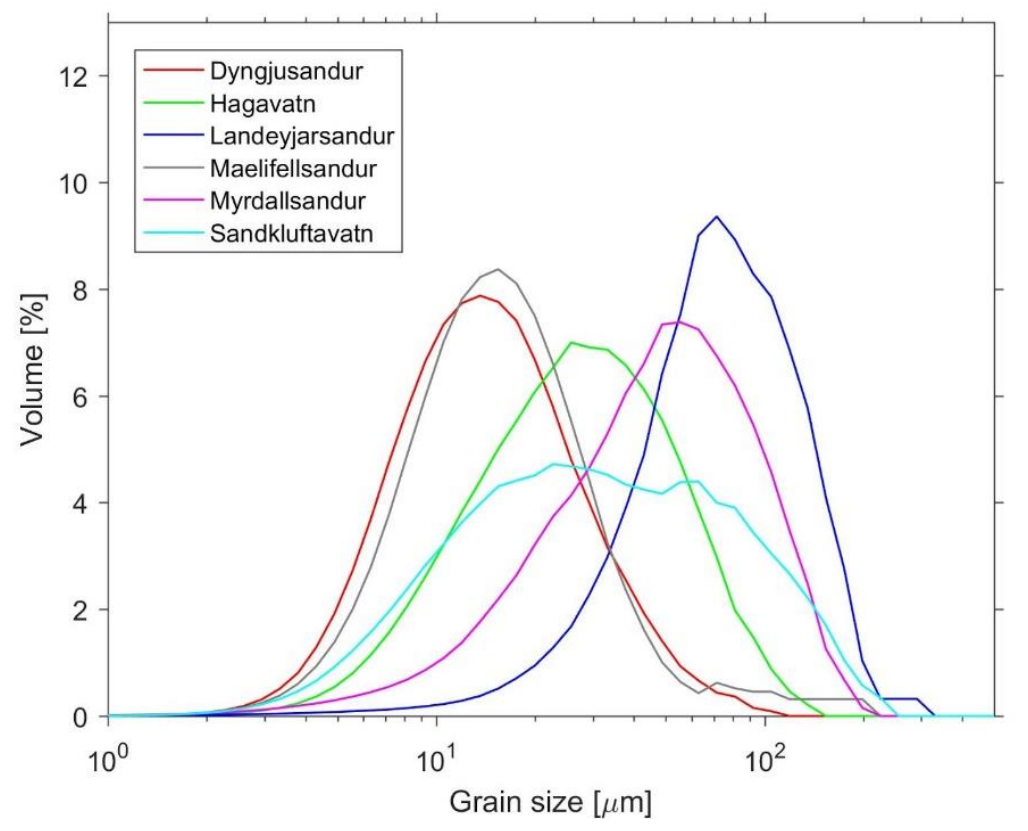

Figure 7. Grain size distributions of samples from Icelandic source areas (redrawn from Varga et al. 2021).

The Icelandic dust particles have different shape, lower density, higher porosity, increased roughness, and darker colour than other desert dust (Butwin et al., 2020; Richards-Thomas et al., 2021). Icelandic dust particles greater than $20 \mu \mathrm{m}$ retain volcanic morphological properties of fresh volcanic ash. Dust and fresh volcanic ash particles less than $20 \mu \mathrm{m}$ are crystalline and blocky in nature. Icelandic dust particles contain amorphous glass, large internal voids, and copious dustcoats comprised of nanoscale flakes. The amorphous basaltic material is mostly aluminosilicate glass ranging from $8 \mathrm{wt} \%$ (Hagavatn hotspot) to 60$90 \mathrm{wt} \%$, with relatively high total Fe with higher Fe solubility and magnetite fraction than low latitude dust (10-13 wt $\%$, Baldo et al., 2020). PM10 concentrations measured during severe Icelandic dust storms well exceeded $7 \mathrm{mgm}^{-3}$ (DagssonWaldhauserova et al., 2014, 2015; Mockford et al., 2018). Submicron particles contribute with high proportions (> $50 \%$ ) to PM10 mass concentrations as well as number concentrations (Dagsson-Waldhauserova et al., 2014, 2016, 2019). Aeolian transport of $11 \mathrm{t}$ of dust over one meter transect was measured during the severe dust/ash storm in 2010, when grains $>2 \mathrm{~mm}$ were uplifted (Arnalds et al., 2013). The chemical composition of the aircraft collected Icelandic dust particles has a different chemical signature than airborne dust particles transported from the Sahara to Barbados (Sanchez-Marroquin et al., 2020).

425 This can be observed in Fig. 8a and Fig. 8b, where it is shown that the chemical composition of the majority of Icelandic dust particles falls in a different area of the chemical composition ternary diagram than the Saharan dust particles collected in Barbados. One of the most prominent differences between these dusts is the presence of $\mathrm{Ti}$ in $\sim 30 \%$ of the Icelandic dust particles, while this element is almost absent in the Saharan dust particles as well as dust collected in other locations, as shown in Fig. 8c. Furthermore, the chemical composition of the aircraft collected Icelandic dust is consistent with surface scooped 

Icelandic dust has a high ice-nucleation ability, with the potential to influence the radiative and lifetime properties of clouds containing both liquid water and ice.

(a)

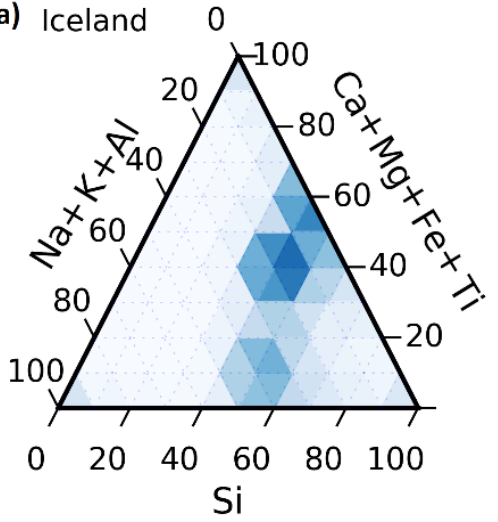

(b)

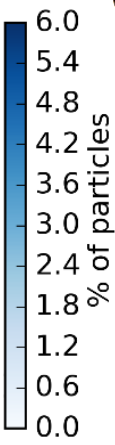

(b) Barbados 0

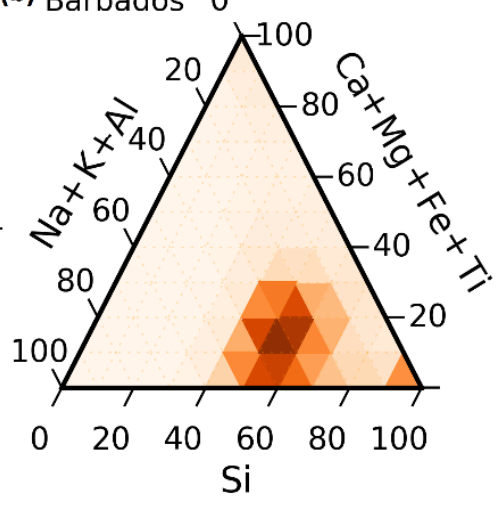

(c)

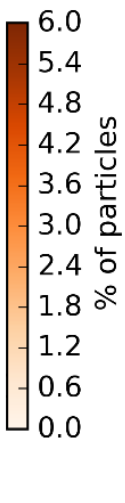

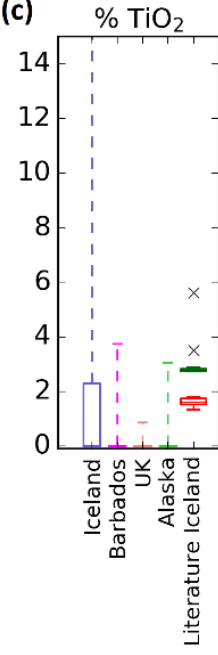

Figure 8. Ternary graphs of the chemical composition of Icelandic dust particles (a) and Saharan dust particles collected in Barbados (b). Each graph contains a heat map with the percentage of dust particles in each sample compositional bin. The chemical composition of each aerosol has been recalculated from the weight percentages given by the SEM software, excluding elements that are not $\mathrm{Si}, \mathrm{Al}, \mathrm{Fe}, \mathrm{Mg}, \mathrm{Ca}, \mathrm{Na}, \mathrm{K}, \mathrm{Ti}, \mathrm{Mn}$ and $\mathrm{P}$. (c) The box represents particles in the Q3 percentile of the percentage of the composition of Ti in all the dust particles in each sample (Icelandic dust, Saharan dust collected in Barbados, dust collected in the UK and dust collected in Alaska). The whiskers represent the composition of all particles located in between the median plus and minus two standard deviations. The data has been compared with the Ti weight percentage of different Icelandic dust and ash samples from the literature. (Figure extracted from the Supplementary Material of Sanchez-Marroquin, 2020).

\subsection{Russia}

\subsubsection{Western Siberia, Altai mountains and Central Kazakhstan}

445 In the most widespread undisturbed soils (Gleysols, Phaeozems, Podzols, Retisols, and Stagnosols) at Western Siberia (Semenkov et al., 2015b, 2015a), - the biggest plain in the world - mineralogical and elemental composition (Supplementary Table S6) were studied using X-Ray diffractometry, X-Ray fluorescence spectrometry, ICP-MS and ICP-AES as well as content of total organic carbon (TOC) as previously reported in detailed in (Semenkov et al., 2019; Semenkov and Koroleva, 2019; Semenkov and Yakushev, 2019). At location No. 4 and 7 (Fig. 1), concentration of N-containing substances and pH 
value were measured in snow in 2009 - 2019 (Koroleva et al., 2016, 2017; Semenkov et al., 2021; Sharapova et al., 2020) as well as dust content in snow and dust deposition rate during winter (Supplementary Table S7).

\subsubsection{Murmansk region: Apatity, Kirovsk, Kovdor}

The development of industry and intensive use of natural resources leads to a significant decrease in the share of reserves of rich ores exploited deposits of practically all minerals. Large amounts of displaced rock mass have been breaking the geological balance. Emissions of gas and dust in mining, dust from dumps and tailing pits, ingress of chemicals and potentially toxic elements in surface and groundwater have negative effects on existing ecosystems and human health, with potentially dangerous impact in the Arctic region. The maintenance of overburdened dumps and tailings dams is costly. Over $150 \mathrm{Mt}$ of industrial wastes are disposed in the Murmansk region annually. Their volume has achieved about 8 Gt. These wastes include off-balance and associated ores stored in heaps $-2.4 \%$, overburden and tunneling rocks (massive and moraine) $-72.4 \%$, processing tailings - about $24 \%$ and the slugs and ashes (up to 1.5\%). Supplementary Table S8 shows the characteristics of tailings dumps of mining enterprises in the Murmansk region. Dusting of processing tailing is one of the main sources of air pollution by suspended matters near the mining enterprises. About $30 \%$ of all suspended matter is released from the mining enterprises into the surface atmosphere due to wind-induced dusting of beaches and slopes of tailings dumps. Elevated concentrations of suspended matters are registered in summer every year in the atmospheric air of Apatity town. Average concentration is exceeded in the periods of unfavourable meteorological conditions, such as north-western winds, weak winds or still weather, compared to winter periods. Dust storms from technogenic dust sources of mining industry on the Kola Peninsula are presented, e.g., in Baklanov et al. (1998, 2012), and Amosov et al. (2014).

\subsubsection{Tiksi}

Aerosol characterization was performed at the Hydrometeorological Observatory (HMO) Tiksi (71.36N; 128.53E), located on the coast of Laptev Sea in Northern Siberia, during 2014-2016 (Popovicheva et al., 2019). FTIR analyses of functionalities, as well as ionic and elemental components provided insight into the dust source-influenced and season-dependent composition of East Siberian Arctic aerosols. Analysis of wind and aerosol pollutants roses combined with long-range transport analysis assist in identifying the sources for dust at Tiksi, demonstrating impacts either from lower latitudes or/and local emissions from the adjacent urban Tiksi area. In warm periods, $\mathrm{Na}^{+}, \mathrm{Cl}^{-}, \mathrm{K}+$, and $\mathrm{Mg}^{2+}$ are found to be the major ions in the sea-salt aerosols which are ubiquitous in the marine boundary layer and significantly impact the dust concentrations in coastal region. Ammonium is mainly produced by the soil and emission from biota and the ocean; it is commonly found in the form of $\left(\mathrm{NH}_{4}\right)_{2} \mathrm{SO}_{4}$ and $\mathrm{NH}_{4} \mathrm{Cl}$. Similar to sulfates, ammonium is influenced by regional sources of secondary aerosol formation and transport. Bands of carbonates $\mathrm{CO}_{3}{ }^{2-}$ (at $871 \mathrm{~cm}^{-1}$ ) and ammonium $\mathrm{NH}_{4}{ }^{+}\left(3247 \mathrm{~cm}^{-1}\right)$ indicate the dominances of dust carbonates in inorganic natural aerosol. Additionally, S, Fe, Na, Al, Si, Ca, Cl, K, Ti, Mn, Co, Cu, Zn, Ga, Sr, Ba, Hg, and Pb were detected in the background dust, with sulfur displaying the highest concentration, followed by $\mathrm{Fe}, \mathrm{Na}$, and $\mathrm{Al}$. 
According to individual particle analyses by SEM-EDX, during the summer and autumn when the wind is from the southwest and air masses arrive from the ocean, aerosol particles demonstrate a large variability in shapes, sizes, and composition, (Fig. 9.1). Elemental composition is characterized by dominant weight percent of $\mathrm{C}, \mathrm{K}, \mathrm{Na}, \mathrm{Cl}, \mathrm{O}$, and $\mathrm{Fe}$. Distribution of elements over particles is heterogeneous, with more frequent $\mathrm{Cl}, \mathrm{K}$, and $\mathrm{Na}$ than $\mathrm{C}$ and $\mathrm{O}$ in around $50 \%$ of particles indicating background aerosols which contain soil, salts, minerals, and carbonaceous compounds. Group Na-rich with dominant $\mathrm{Na}$ and $\mathrm{Cl}$ is found the most abundant, $32.5 \%$. It is originated from sea spray in vicinity of the ocean (Fig.9.2). The other particles, contain small amounts of $\mathrm{K}, \mathrm{Ca}$, and $\mathrm{Mg}$ from sea water impurities, as well as $\mathrm{S}$ gained through acid displacement. The second most abundant group of individual particles is Group K-rich, $28.8 \%$, dominated by $\mathrm{K}$ and $\mathrm{Cl}$. They are not of marine origin because the concentration of nss $\mathrm{K}^{+}$ions significantly exceed the possible concentration of $\mathrm{K}$ in SSA. They are particles of natural mineral sylvite $(\mathrm{KCl})$ but transformed from genuine ones because the averaged weight ratio $\mathrm{K} / \mathrm{Cl}$ was found equal to 3.3, significantly higher than 1.1 in sylvite (Fig.9.3). $\mathrm{KCl}$ is water soluble and may react in the polluted atmosphere. Variation of $\mathrm{wt} \%$ of $\mathrm{K}$ vs $\mathrm{Cl}$ shows the lack of $\mathrm{Cl}$ in comparison with genuine sylvite and the formation of complex chemical compounds $\mathrm{K}_{\mathrm{x}} \mathrm{Cl}_{\mathrm{y}}$ with a various number of $\mathrm{K}$ and $\mathrm{Cl}$ atoms. Representative micrograph of particles in Group K-rich demonstrate the reacted sylvite, Fig.8.3 with a small damage by electronic beam that can prove the presence of nitrates which were easily evaporated during EDX analyses. A part of Group Na-rich and K-rich, $20 \%$ and $5 \%$, respectively, contains $\mathrm{Na}, \mathrm{Cl}$, and $\mathrm{K}$, and is assumed to be particles of natural sylvite mineral composed from alternative layers of halit and sylvite $(\mathrm{nNaCl}+\mathrm{mKCl})$ (Fig.9.4). They have distinctive mineral shape and are stable with respect to evaporation by electron beam. About $14.8 \%$ of individual particles compose Group Organic made almost from $\mathrm{C}$ and $\mathrm{O}$. They are found either roughly spherical or liquidlike shape (Fig.9.5). Around a half of them contain only $\mathrm{C}$ and O, being probably secondary organic aerosol of biogenic source. The other half is from seawater of the Arctic Ocean as demonstrated by trace amounts of $\mathrm{Na}, \mathrm{Cl}$, and $\mathrm{Mg}$. Oxidation of volatile organic compounds, humic-like substances (HULIS) in the marine environment, is perhaps contributing to observed organic matter. Finally, a few biogenic particles such as pollen, spore, algae, bacteria, and plant or insect remnants are found in natural aerosols, indicated by specific shape and the presence of $\mathrm{K}, \mathrm{S}, \mathrm{Si}$, and $\mathrm{Cl}$ together with $\mathrm{C}$. The remaining Groups Fe-rich (14.4 $\%)$, Ca-rich (6.4\%), and Al, Si-rich (3\%) are representative of atmospheric dust, derived from the Earth's crustal surface. Dust particles have solid irregular shapes of round and euhedral morphology. Analyses of the soil sample taken near the CAF showed stony material with very limited fertile ground cover. EDX analyses demonstrated 27.7 and $9.8 \mathrm{wt} \%$ of Si and Al, 46 and $10.6 \mathrm{wt} \%$ of $\mathrm{O}$ and $\mathrm{Fe}$, respectively, and $3.5 \mathrm{w} \%$ of $\mathrm{K}$ in various $\mathrm{Fe}, \mathrm{K}$ - aluminosilicates containing small additives (less than $1.7 \mathrm{wt} \%$ ) of $\mathrm{Na}$ and $\mathrm{Mg}$. Since tiny dust of stony soil may be easy dispersed into the atmosphere by wind we assume that Group Al, Si-rich and around a half of Group Fe-rich is composed from $\mathrm{Fe}, \mathrm{K}$ - aluminosilicates (Fig.9.6). Group Fe-rich containing $\mathrm{Fe}, \mathrm{Ni}, \mathrm{Ca}$ and $\mathrm{Si}$ is composed from soil particles of iron-nickel ore (Fig. 9.7). Finally, Ca carbonates and sulfates with $\mathrm{Ca}, \mathrm{C}, \mathrm{S}$, and $\mathrm{O}$ are found in Group Ca-rich, Fig.8.8, according to observation of $\mathrm{Ca}^{2+}, \mathrm{CO}_{3}{ }^{2-}$, and $\mathrm{SO}_{4}{ }^{2-}$ ions described above. Together with aluminosilicates, they are most likely windblown dust. 

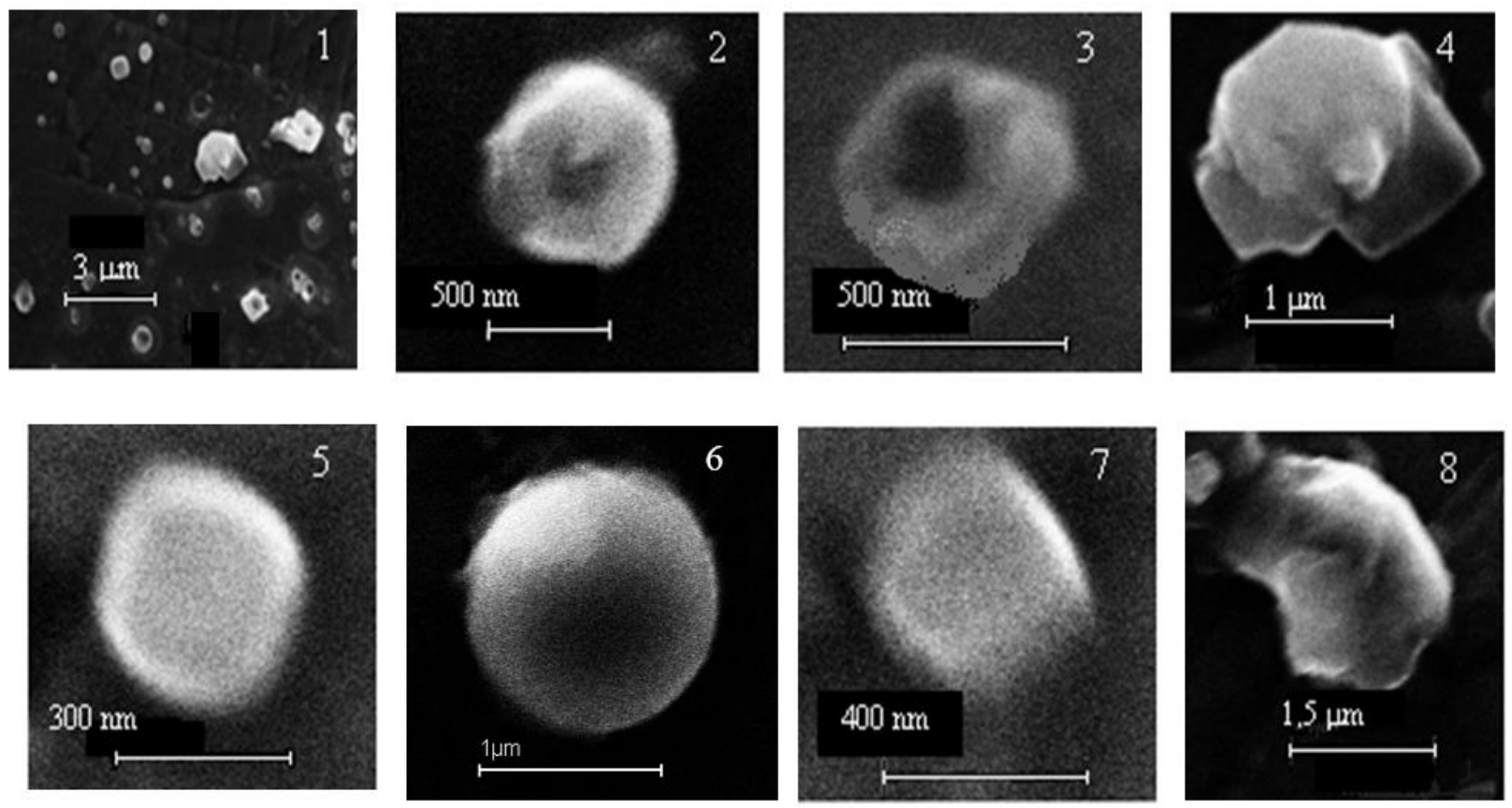

Figure 9. 1. Panorama and representative micrographs of natural background aerosols at HMO Tiksi; 2. reacted sea salt NaCl in Group Na-rich; 3. reacted sylvite $\mathrm{KCl}$ and 4. sylvinite $(\mathrm{nNaCl}+\mathrm{mKCl})$ in Group $\mathrm{K}$-rich; 5. an organic particle in Group Organic; 6. Fe, Ca- aluminosilicate in Group Al, Si-rich; 7. Fe/Ni particle in Group Fe-rich and 8. $\mathrm{CaCO}_{3}$ in Group Ca-rich of natural aerosols on 27.09.2014. New unpublished results of Popovicheva et al. (2019) investigation.

\subsection{South America and Patagonia}

Extending from $39{ }^{\circ} \mathrm{S}$ to $54{ }^{\circ} \mathrm{S}$ and with an area of $600000 \mathrm{~km}^{2}$, dust activity (Fig. 10) from this large desert remains largely unknown. Some basic facts have to be formally assessed such as location of sources and geomorphological features associated with dust, seasonality and frequency of their activity. To date, there are limited surveys of dust activity (Crespi-Abril et al., 2017; Gaiero et al., 2003; Gassó and Torres, 2019) and case studies of individual sources (Gassó et al., 2010; Gassó and Stein, 2007; Johnson et al., 2011). Recently, a list of dust activity and sources in Tierra del Fuego (Cosentino et al., 2020) have been published. In general, dust sources in Patagonia are located at topographic lows and the river valleys (e.g., the Deseado and Santa Cruz rivers (Coronato et al., 2017; Hernández et al., 2008) associated with the late Holocene para-glacial environments). The most active modern source of dust is the drying Colhué Huapi Lake (CHL) located in Central Patagonia (45.5 ${ }^{\circ} \mathrm{S}$ and 68 ${ }^{\circ} \mathrm{W}$ ) (Montes et al., 2017). This is a shallow lake with variable water levels and exposed to intense evapotranspiration. Also, it appears there is an anthropogenic component linked to intense farming, oil prospection and supply of water to urban centers (Gaitán et al., 2009; Hernández et al., 2008; Mazzonia and Vazquez, 2009; Valle et al., 1998). CHL has been steadily shrinking 
https://doi.org/10.5194/acp-2021-963

Preprint. Discussion started: 17 December 2021

(c) Author(s) 2021. CC BY 4.0 License.

(c) (i)

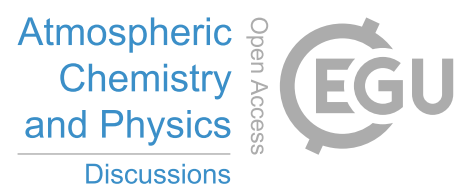

(Llanos et al., 2016) and it was fully dried up by the summer of 2020. Consequently, dust activity originating in CHL has been increasing with frequent blowouts large enough to can be easily detected from space (Gassó and Torres, 2019). 


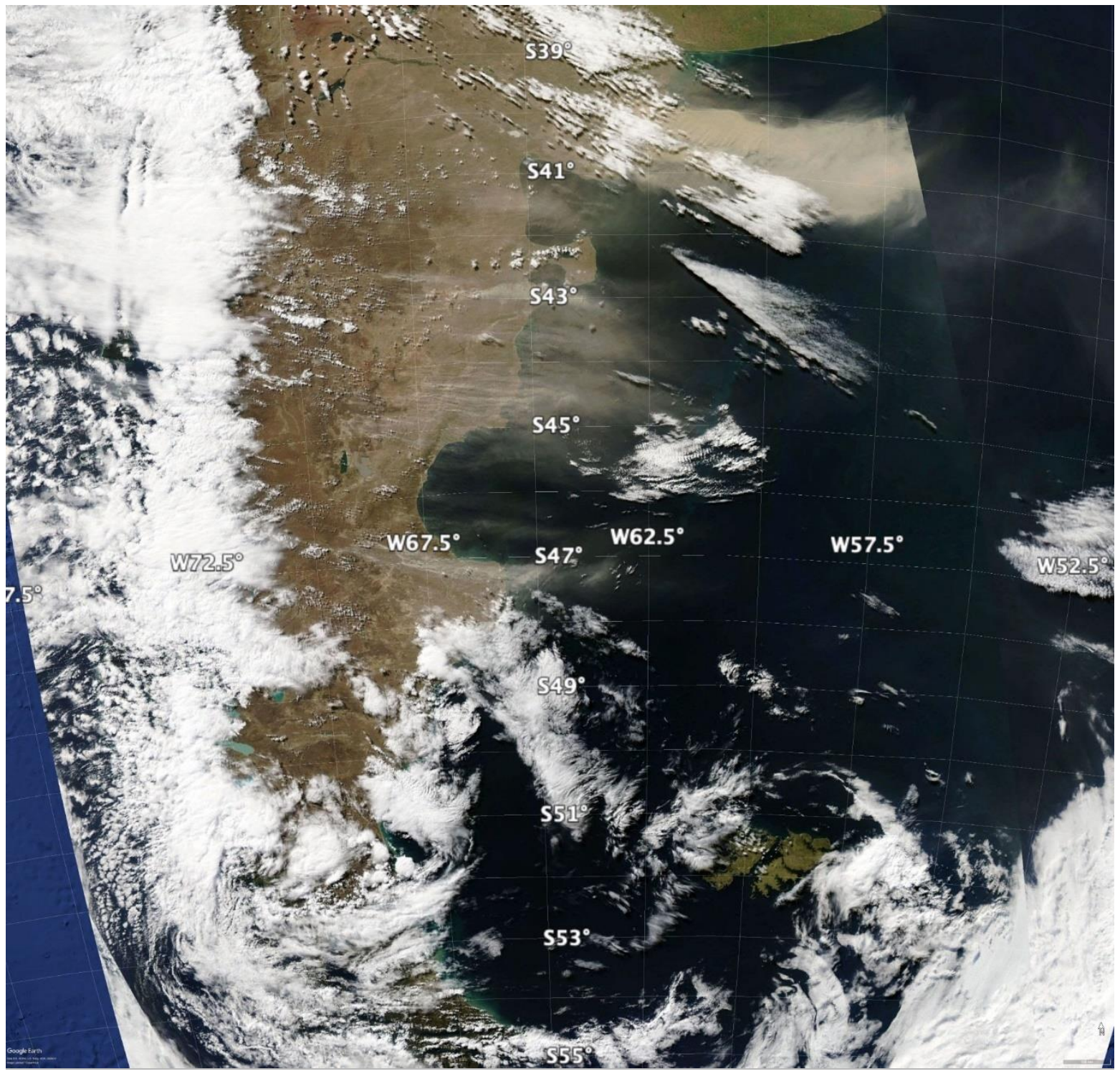

Figure 10. A dust event spanning the north and central sections of the Patagonian Desert $(+\mathbf{1 0 0 0} \mathbf{k m})$ on March 28, 2009. Events this large occur about once every one to three years. This event is typical in that it was triggered by the passage of a powerful lowpressure center commonly found in these high latitudes. Also, this event is singular in that a large portion of it is cloudless enabling the direct view from space (most of dust activity in Patagonia occurs under cloudy conditions). The thick dust cloud in the upper right corner is from an area used for cattle farming and it was undergoing a drought whereas the active sources further south can be considered more naturally occurring with less anthropogenic interference. Source: NASA's Worldview interface image processed with $\odot$ Google Earth. 
545 Overall, satellite detection in the Patagonia region remains a challenge. There are several difficulties in surveying dust activity in the area (obstructed views from space because of cloudiness, night time dust activity and sparse population). In addition, except for a few sources, the lack of recurrence in dust emission is a general feature of the desert: sources that were active during one season do not reactivate until two or three seasons later. A comprehensive and dedicated survey combining surface as well space-based detection networks are needed to get a better understanding.

\subsection{Svalbard}

Evidence on the presence and activity of dust sources in Svalbard are only recent and quite rare, yet dust storms in Longyearbyen, for example, are reported as a regular feature in autumn. Dörnbrack et al. (2010) documented and characterized a strong dust storm that occurred in the Adventdalen valley, center of the Spitsbergen Island, in May 2004, by airborne lidar observations and mesoscale numerical modeling. In the same area, near Longyearbyen, the presence of dust emissions from an active coal mine has been documented in Khan et al. (2017). Kandler et al. (2020) also report Svalbard measurements in Longyearbyen, in September 2017, with high iron and chlorite-like contributions in dust.

The accelerated ablation of Svalbard's glaciers (Schuler et al., 2020) and the increasing rate of melting of permafrost are causing accelerated growth in periglacial and proglacial areas with increasing significance of the morphogenetic processes of deflation, denudation, and of sediment transport on slopes and in river channels in the marginal zones of glaciers (Zwolinski et al., 2013). These areas have therefore become potential sources of dust and, as such, they have been investigated as for the physico-chemical properties of their sediments regardless of the occurrence of documented dust events over them.

Fluvial, glaciofluvial and weathering deposits at five different sites on the coastal plains in the vicinity of the Ny-Ålesund 565 Research Station $\left(78.92481^{\circ} \mathrm{N}, 11.92474^{\circ} \mathrm{E}\right)$, NW Spitsbergen were investigated (Moroni et al., 2018). The mineralogical assemblage is characterised by the presence of dolomite, calcite, quartz, albite, and sheet silicates (vermiculite, muscovite, clinochlore) in variable amounts, along with monazite, zircon, apatite, baryte, iron sulfate, $\mathrm{Fe}, \mathrm{Ti}, \mathrm{Cu}$, and $\mathrm{Zn}$ ores as accessory minerals. With a weight fraction of 4 to $53 \%$ of particles smaller than $100 \mu \mathrm{m}$, these deposits are to be considered a valid source of dust although the contribution is necessarily influenced by the modest extension of bare soils (less than $4 \mathrm{~km}^{2}$ ) and the short duration of the driest summer period in this area. The composition of the aerosols collected at the Gruvebadet lab, near Ny-Ålesund, in the summer-fall period reveals the presence of such a local component of dust (Moroni et al., 2016; Moroni et al., 2018). Further evidence of local dust sources in the Ny-Ålesund area and the Brøgger peninsula also result from the chemical composition of the annual snowpack (Gallet et al., 2018, Jacobi et al., 2019). The contribution from local dust sources on this site is of secondary importance compared to the contribution from long-range transport (Moroni et al., 2015; Moroni et al., 2016; Moroni et al., 2018, Conca et al., 2019). 
A similar study was conducted on the loose sediment deposits in the neighbourhood of the Polish Polar Station Hornsund $\left(77.00180^{\circ} \mathrm{N}, 15.54057^{\circ} \mathrm{E}\right)$, SW Spitsbergen. There, a belt of nearshore plains consisting of marine terraces and nival moraine bars, with bare surfaces available for mineral dust uplift from late spring, widely outcrop (Zwolinski et al., 2013). The mineralogical assemblage consists of quartz, alkali-feldspar, plagioclase, dark mica and chlorite, with zircon, apatite, monazite, iron sulfide and Fe ore as accessory minerals. The same assemblage was found both in the aerosols and the snow cover collected at the base station and the surrounding glaciers in the same period. This fact, along with the great proportion of particles smaller than $50 \mu \mathrm{m}$ in the loose sediment deposits, supports the prevalence of the local source of dust in the melting season. Further evaluation of the impact of local dust sources was obtained from the analysis of shallow and deep cores from different glaciers in the Hornsund area (Lewandowski et al., 2020; Spolaor et al., 2020). The results suggest that for Spitsbergen glaciers with the summit close (Ny-Ålesund) or below (Hornsund) the equilibrium line, the summer dust deposition from the local sources is predominant and affects the chemical composition of the glacier ice. However, the dating of monazite grains and the presence of magnetite and iron sulfide also suggest the presence of regional wind transport from the areas of Nordaustlandet and Edgeøya, respectively. In addition, the presence of a long-range component from Northern Europe, Siberia and, to a limited extent, from Greenland, Greenland, and Iceland and Alaska was also evidenced (Moroni et al., 2018; Crocchianti et al., 2021). Recent estimation of dust load in Central and Southern Svalbard from different sources range from $4 \mathrm{~g}$ up to $4 \mathrm{~kg} \mathrm{~m}^{-2}$ (Rymer, 2018), with highest values in the Ebba Valley due to frequent occurrence of dust storms in this area (Strzelecki and Long, 2020). Kavan et al. (2020a) found a negative correlation between deposition rate and altitude at both Pyramiden ( $78.71060^{\circ} \mathrm{N}$, 16.46059 $\left.{ }^{\circ} \mathrm{E}\right)$, west coast of Petuniabukta, and Ariekammen $\left(77.00035{ }^{\circ} \mathrm{N}, 15.53674{ }^{\circ} \mathrm{E}\right)$, Hornsund area. The pattern was clear up to the altitude of approximately $300 \mathrm{~m}$ a.s.l. suggesting the influence of local sources in the lower levels of the atmosphere and long-range transport at higher altitudes. The lower values of the deposition rates found at Ariekammen were ascribed due to the more frankly maritime climate of the Hornsund region.

\section{Modeling results on high latitude dust}

The use of regional-scale modelling of dust atmospheric transport from potential Arctic dust sources is described and demonstrated here, including the DREAM dust model (Section 6.1) and the SILAM long-range transport model (Section 6.2). Transport modelling results are essential when discussing the various aspects related to the environmental and climatic significance of dust in the high latitudes (Section 7). The DREAM dust model results are also included in discussing the significance of HLD and long-range transported dust in Antarctica.

\subsection{DREAM model results}

605 Accelerated warming in the Arctic and Antarctica is triggered by various processes in which aerosol plays a significant role at high latitudes. Dust aerosol in particular changes snow/ice albedo and melting rates, affects the marine productivity, alters microbial dynamics in glaciers and causes indirect (cloud formation) and direct (solar radiation) effects. Dust models 
implemented over HL regions, combined also with available observations, can contribute to better understanding of processes in which dust plays an important role as a climate change driver in polar regions (IPCC, 2019). Following the interest of the international community to study dust environmental and climate impacts in high latitudes, a fully dynamic numerical prediction model for dispersion of dust from the largest European dust sources in Iceland (DREAM-ICELAND) has been developed (Cvetkovic et al.,2021, submitted). The dust component of such modeling system - the dust DREAM model (Pejanovic et al., 2011; Nickovic et al., 2016) is fully coupled with the atmospheric model driver NMME - the NCEP Nonhydrostatic Mesoscale Model on E-grid (Janjic et al., 2001). The on-line coupling two models secure simultaneous interaction 615 between meteorological parameters and dust concentration during the simulation/forecasting process. Dust concentration in the DREAM-ICELAND is embedded as one of the governing prognostic equations which include eight particle size bins with radii ranging in the interval $0.18-9 \mu \mathrm{m}$ with a particle size distribution specified according to in-situ measurements in the Icelandic hot spots. The first four bins are considered as clay particles and another four as silt particles. The model horizontal resolution of $\sim 3.5 \mathrm{~km}$ is sufficiently fine to resolve rather heterogeneous and small-scale distribution of the Icelandic dust sources (Fig. 11). DREAM-ICELAND, being the first operational numerical HLD model in the international community, is used to daily forecast Icelandic since April 2018 shown at the Republic Hydrometeorological Service of Serbia (RHMSS) site (Fig. 12), also available at the WMO SDS-WAS dust portal (https://sds-was.aemet.es/news/new-icelandic-dust-forecast).

The main purpose of developing DREAM-ICELAND was for the provision of daily dust forecasts. Another objective for its use was studying various longer-term dust interactions with the environment and climate, such as effects of dust mineralogy to marine bio-production, impacts on the radiation balance, dust-cloud interactions, and darkening of snow/ice surfaces by dust.

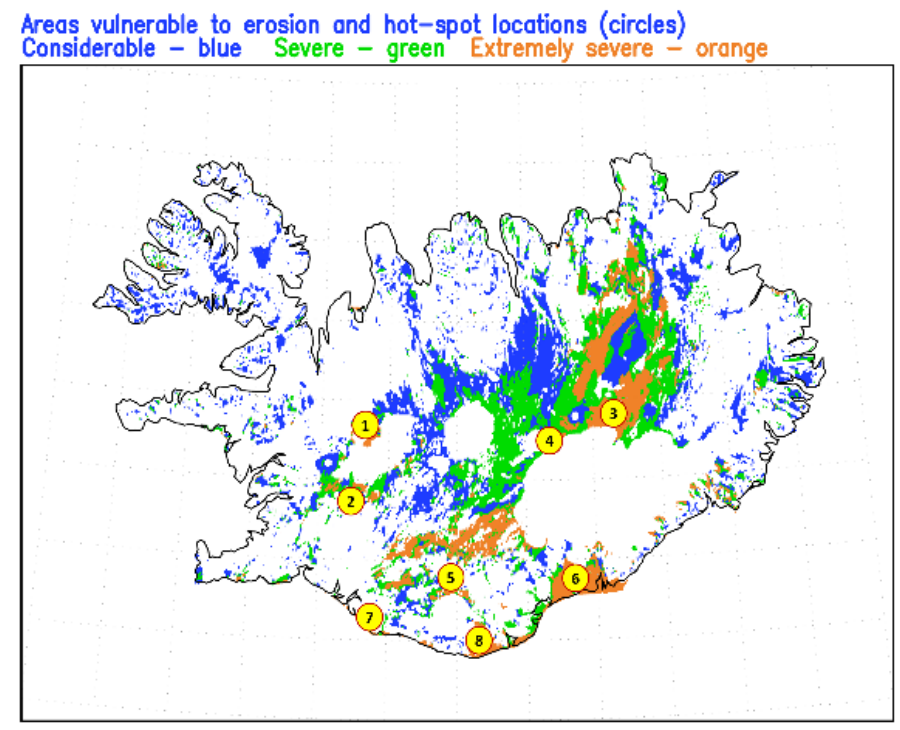


https://doi.org/10.5194/acp-2021-963

Preprint. Discussion started: 17 December 2021

(c) Author(s) 2021. CC BY 4.0 License.

(c) (i)

\section{Atmospheric \\ Chemistry \\ $\frac{\text { and Physics }}{\text { Discussions }}$}

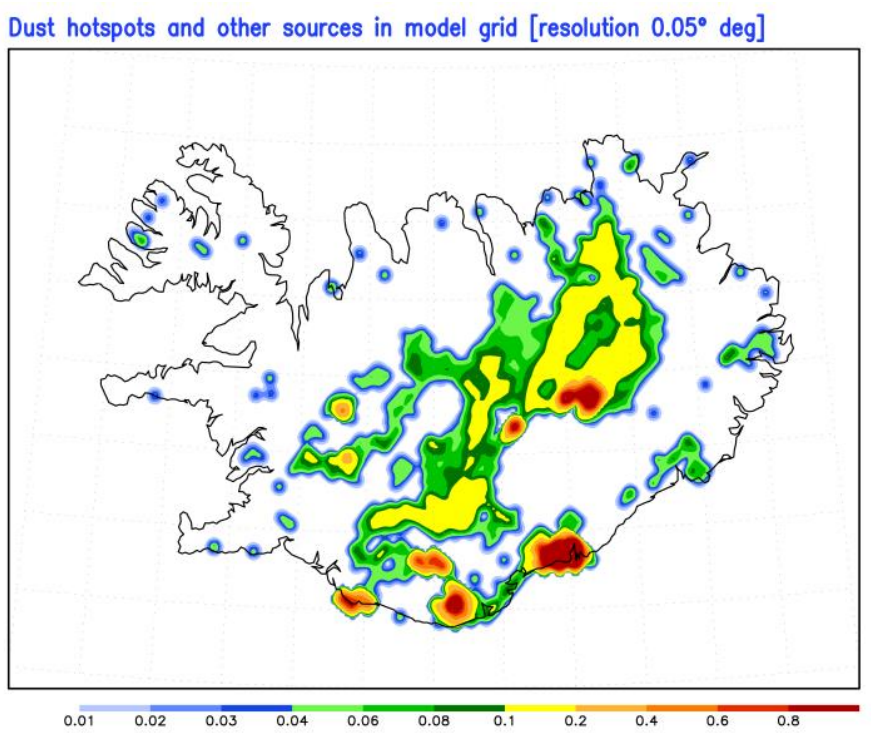

635 Figure 11. (A) Above: Areas vulnerable to erosion according to Arnalds et al. (2016) (extreme - orange, severe - green, considerable - blue) and hot-spots of dust emission (yellow circles); Dust hot-spots geographical names: 1-Flosaskaro, 2-Hagavatn, 3Dyngjusandur, 4-Vonarskarð, 5-Mælifellssandur, 6-Skeiðarársandur, 7-Landeyjarsandur, 8-Mýrdalssandur. (B) Below: Derived dust source mask for Iceland as seen on the model horizontal resolution of $\sim 3.5 \mathrm{~km}$. Areas vulnerable to erosion (extreme - orange, severe - green, considerable - blue) and hot-spots of dust emission (yellow circles). 
https://doi.org/10.5194/acp-2021-963

Preprint. Discussion started: 17 December 2021

(c) Author(s) 2021. CC BY 4.0 License.

(c) (i)
Atmospheric

Chemistry

and Physics

Discussions
DREAM8-Iceland: Surface dust concentration $\left(\mu \mathrm{g} / \mathrm{m}^{3}\right)$ and $10 \mathrm{~m}$ wind $(\mathrm{m} / \mathrm{s})$
Forecast base time: O4SEP2020 OOUTC Valid time: O4SEP2020 15UTC

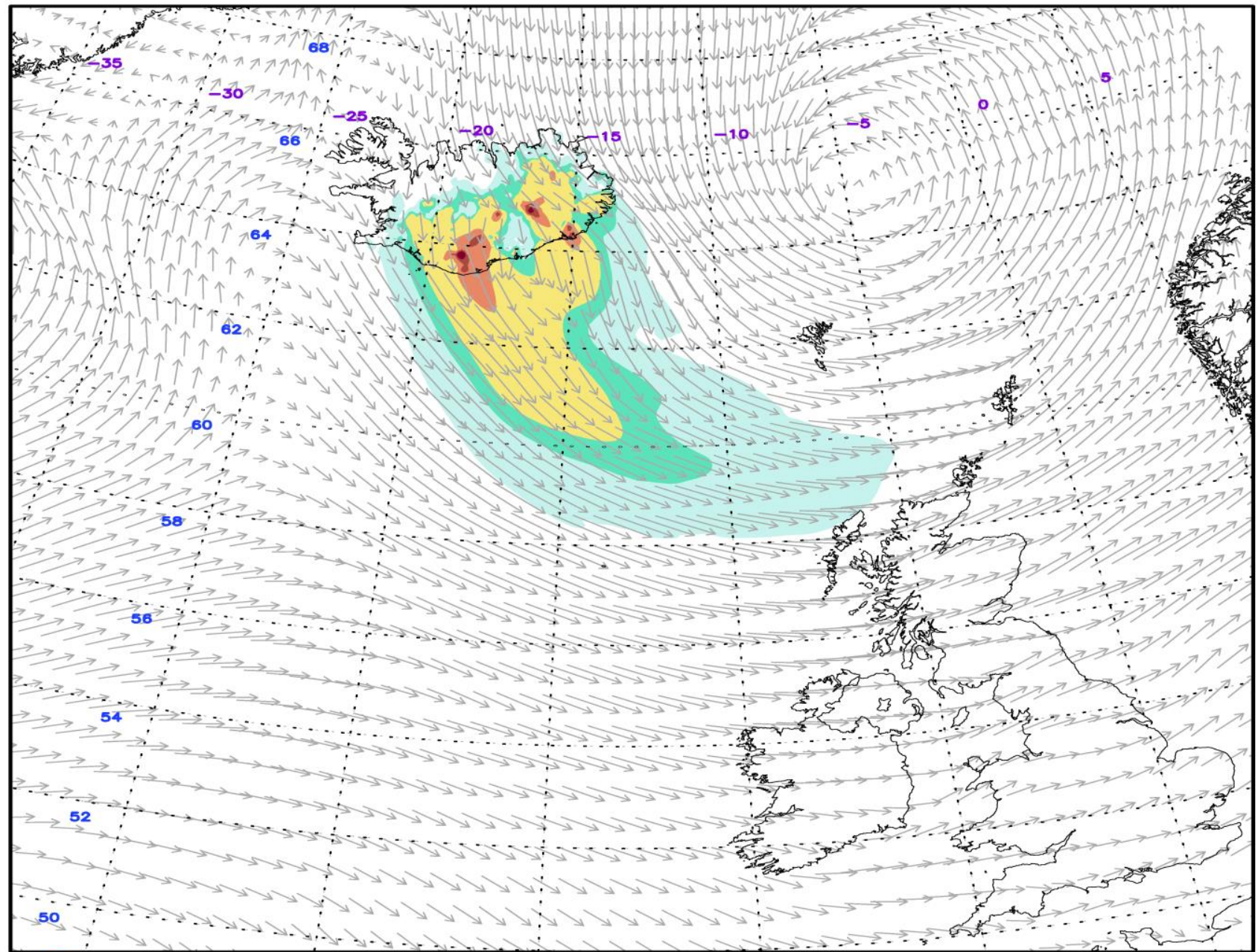

$\infty$ SEEVCCC

$\begin{array}{llllll}20 & 5 & 25 & 50 & 200 & 500\end{array}$




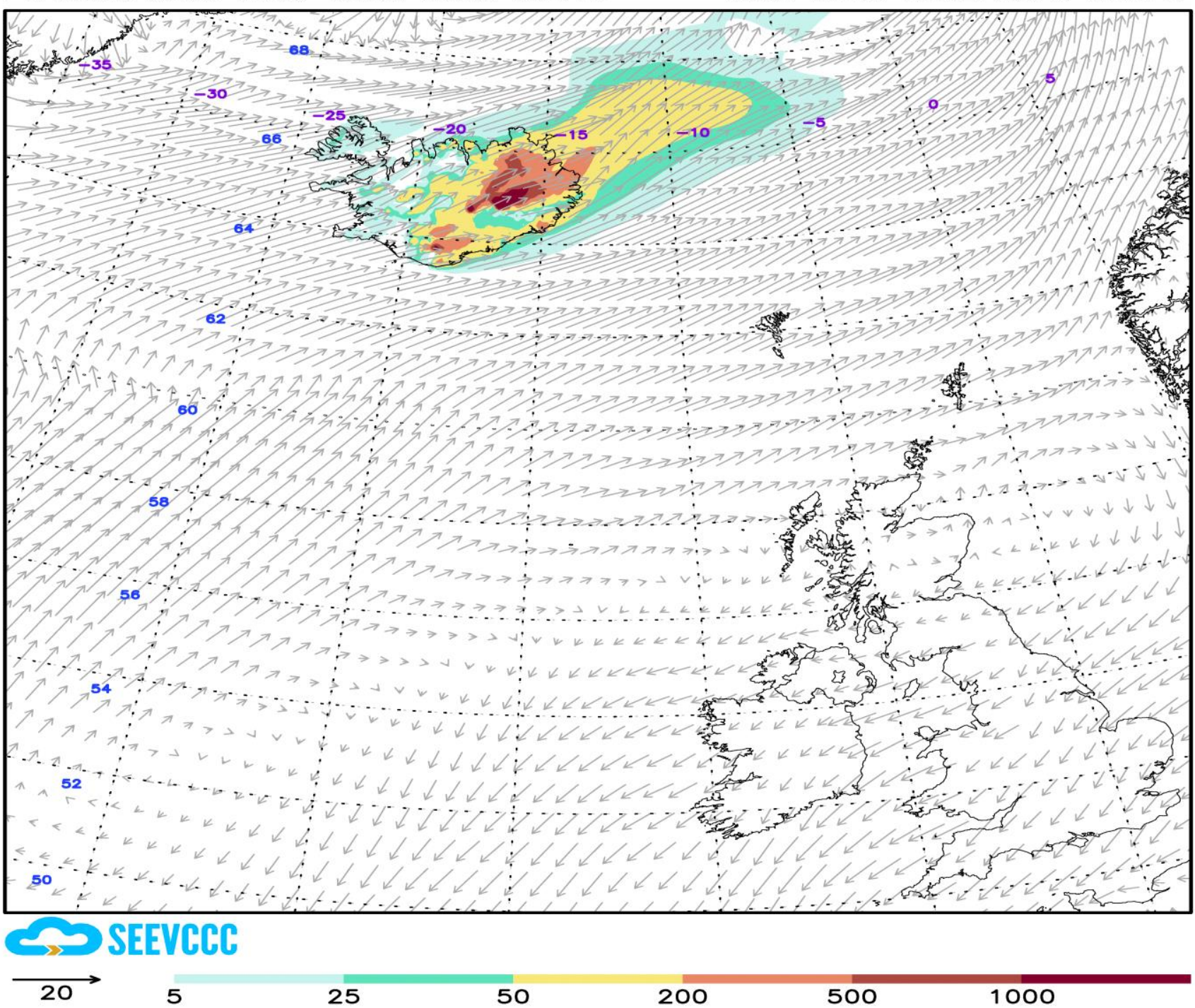

Figure 12. An example of the operational Icelandic dust surface concentration forecast (http://www.seevccc.rs/?p=8)

The observational inventory presented in this study shows numerous examples of dust emissions in HL regions frequently generated from point-like sources. Relatively coarse resolution of current global dust models, typically of several tens of km, cannot well resolve such small-scale source structures. Recent development of the UNCCD global 1km "Sand and Dust Storm (SDS) Basemap" database (Vukovic, 2021) provides information on potential dust sources, complementing the observational evidence, which could be very useful input to dust models. In a model experiment in which the SDS Basemap is used to specify 
dust sources (Fig. 13A), a circumpolar version of the DREAM model has been developed in RHMSS (Pejanovic, personal communication). The model capability to simulate dust airborne process was tested over the region for latitudes $>60^{\circ}$. By locating the geographic centre of the model at the North Pole, strong convergence of the model "meridians" in its transformed coordinates has been avoided, permitting so time-efficient execution of the model with horizontal grid spacing much finer than resolutions of global models. The circumpolar DREAM with the resolution of $\sim 10 \mathrm{~km}$ was run over a $24 \mathrm{~h}$ period in a realtime experiment for 4 November 2013, predicting appearance of simultaneous HLD emissions from Icelandic soils and the northern coastline of Canada (Fig. 13C). NASA MODIS observations confirm the existence of all three predicted emission patterns (Fig. 13B).

A

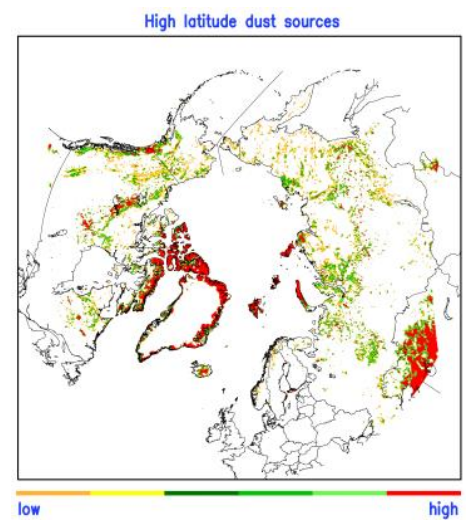

B

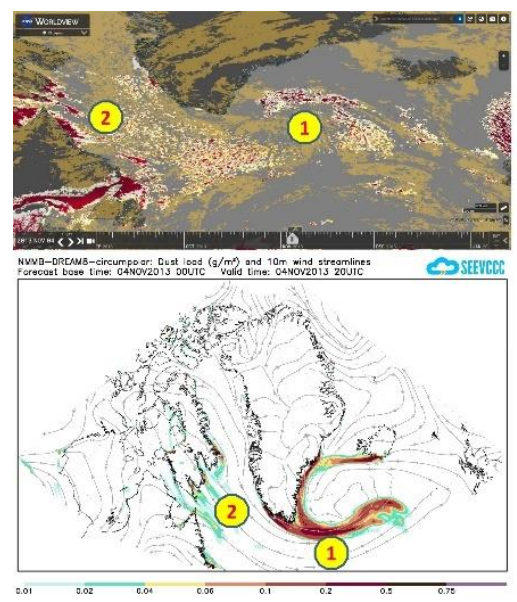

Figure 13. NMMB DREAM circumpolar model experiment. A) The global sand and dust storms source base map (G-SDS-SBM; Vukovic, 2019, 2021); B) MODIS AOD (upper) and C) DREAM predicted dust load (lower) for 4 November 2013.

\subsection{SILAM model results}

SILAM is a global to meso-scale atmospheric dispersion and chemistry model, applied for air quality and atmospheric composition modelling (Sofiev et al., 2015). SILAM utilizes an effective dust emission model, where the emission depends on $\mathrm{A} *(\mathrm{v} 10 \mathrm{~m}$ - vmin) 3 , where $\mathrm{v} 10 \mathrm{~m}$ is the $10 \mathrm{~m}$ wind speed, the parameter A depends on the surface roughness, the bare land fraction, and the snow depth, and the parameter vmin depends on the surface soil moisture, having a minimum value of $5 \mathrm{~m} / \mathrm{s}$.

675 The dust emission estimate is driven by the ECMWF IFS meteorological model at a resolution of $0.1 \times 0.1$ degrees. While a theoretical approach, based on the conservation of momentum within a saltation process, suggests a more complicated 
expression for the emission based on the friction velocity at the surface (Kok et al., 2014), such an approach may face difficulties when implemented within a large-scale dispersion model. Firstly, the calculation of the friction velocity itself is not straightforward (Foroutan et al., 2017), and secondly, strongly nonlinear microscopic scale emission models cannot be accurately represented on grids that are coarse with respect to the details of the terrain. Thus, when applied in SILAM, the effective model has yielded much better comparisons against in situ and satellite measurements than a detailed model based on saltation theory. For Iceland specifically, more measurements would be needed for further validation of the model.

In Figure 14, dust emissions in Iceland are presented in three months periods (March 2020 - August 2021). The modeled results clearly show the seasonal nature of the dust sources, which is in accordance with the results presented in Section 4 . The summer season from June to August appears in general, to be the strongest dust season. In wintertime, with snow covered land surfaces, there are dust emissions, too. This is in accordance with observations on dust event occurring during snow (e.g., DagssonWaldhauserova et al. 2015). The 2021 summer season in these modeled emission results appears in the same locations as in summer 2020, but with more severe emissions in the highlands in 2021. This agrees with the field observations in Vatnajökull national part during HiLDA measurement campaign in the 2021 season (https://gomera.geo.tu-darmstadt.de/wordpress/), where most severe dust events were measured. The correlation of modeled and measured PM10 and PM2.5 total aerosol concentration is low especially in 2018 , which can be mostly explained by the measurement locations being far from the source locations and instead show the effects of road dust than long-range transported dust. In addition, the Reykjavik and Akureyri nearby dust inventory is unrepresentative, as a result of the challenge to fit the modeled long-range transported dust emissions to the measurement data within the 0.1 degrees model resolution. Near Reykjavik, dust emissions, e.g., from Landeyjasandur, may contribute to the measured dust concentrations, but the 0.1 degrees resolution of the model is too scarce to simulate them. 

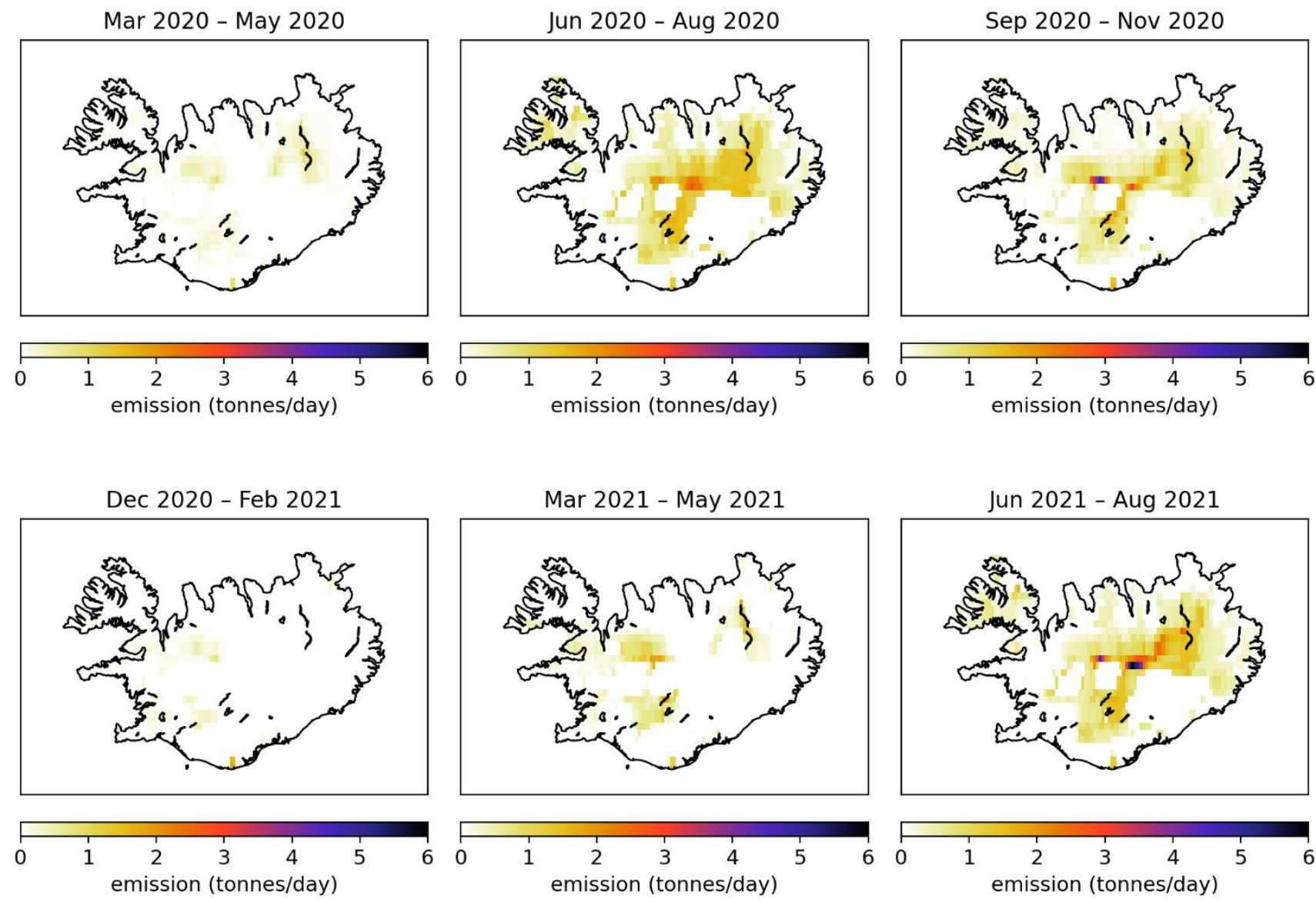

Figure 14. SILAM modeled dust emissions for Iceland.

\section{Discussion}

The HLD overview results with the environmental and climatic significance of HLD are discussed here as follows: i. source intensity values; ii. comparison with available HLD information on the various regions; iii. geological perspective on sources, focusing a gap identified in HLD observations for Central part of East European Plain and dust particle properties; and iv. local HLD sources and long-range transport of dust with the focus on results from the observations in Svalbard and Antarctica.

705 In addition, the key climatic and environmental effects of the HLD emissions on clouds, climatic feedbacks, atmospheric chemistry, marine environment, and cryosphere-atmosphere feedbacks are discussed. 


\subsection{Source intensity values}

Majority of the HLD study locations agree with UNCCD G-SDS-SBM source intensity (SI) values of the highest dust productive areas, identifying an environment from a given mark location within a distance $\leq 0.1^{\circ}$. Surfaces with higher maximum SI include significant portion of land surface in HLD regions. In the south HLD region, annual change of SI exists but still about half of the dust productive surface stay exposed to wind erosion during the year. In the north HLD region, SI intensity varies significantly with the weather conditions. High values of SI may not always coincide with the occurrence of high surface winds, which means high values may exist but not necessarily result in a dust storm, or in case emissions occur it may remain undetected because of the absence of ground observations over the majority of the HLD region, and frequent cloud cover over the airborne dust obscuring remotely sensed imagery.

Based on the SI values, the East Greenland sources included in this study (No. 58 - 64) are seasonal sources, meaning that their SI minimum value is zero. On the contrary, the West Greenland sources identified here are not necessarily seasonal, since their SI minimum values are somewhat reduced, but not to zero. However, the term "seasonal" regarding the SI values means that the soil surface conditions are good for dust emissions, but it doesn't mean it will happen. Similarly, the seasonality of all sources in this collection can be further studied.

When the newly identified sources are geographically close to each other, it might indicate that they are part of the larger dust source area, like South Iceland, West Greenland, or East Greenland. The discovered sources could be considered to represent the hot spots, i.e., the most emissive and/or active locations, of those dust productive areas. However, at the same time, the land surface and soil composition can be very complex and spatially variable, and the identification of single sources justified until the source characteristics and particle properties have been characterized more in detail. For example, Icelandic sources have shown that each source, even located closely, may have different particle size distributions and optical properties.

730 Uncertainties of the detected locations of the HLD sources and the G-SDS-SBM source intensity values arise from the methodology for determining HLD source locations (ad-hoc location sources from satellite images of dust plumes or other kind of airborne dust observations may introduce some error in location estimation compared to on-site land surface monitoring, and precision of available data locations) or from resolution of G-SDS-SBM, which may be too coarse for small scale source areas (in this case representative grid point value show reduced source intensity value since it is representative for the whole grid box). However, the in-point (at location) values are also given maximum values in the area around the given location (one point distance $-30 \mathrm{arcsec}, 0.1^{\circ}, 0.5^{\circ}$ and $1^{\circ}$ distance). Values of source intensity above 0.9 have topsoil potential for SDS production in top $10 \%$ of grid boxes with some emission potential in G-SDS-SBM (or in top $10 \%$ most dust productive surfaces globally in case of favourable weather conditions), above 0.8 in top $20 \%$, above 0.7 in top $30 \%$, etc. Factors that reduce source function value, or topsoil dust productivity, are the existence of sparse vegetation, coarser soil 
texture, higher moisture, temperatures near freezing point. Uncertainties in methodology for deriving G-SDS-SBM arise from the quality and resolution of available global datasets as well as the determination of thresholds for EVI in defining bare land fraction (mostly for brown grassland which may appear as potential dust sources but with lower productivity). Surfaces with low SI values in favourable conditions for dust emission, in case of high winds, may produce some blowing dust events, and sources with higher values of SI may produce dust storms. Real dust production from sources depends on appearance of high winds while SI is high.

A total of 49 locations were in the north HLD region (with exception of two sources, no. 8 and 48 , with latitudes $43.7^{\circ} \mathrm{N}$ and $43.6^{\circ} \mathrm{N}$, respectively), while 15 locations are in the south HLD region, including 4 locations south of $60{ }^{\circ} \mathrm{S}$, where the values of SI are not provided. In the north HLD region, higher dust productive potential (SI $\geq 0.5$ ) have 17 of 49 marked locations at exact location of the HLD source marks. In addition, 38 locations are in the area with distance from a mark point (D) equal or less than $0.1^{\circ}$ (Supplementary Table S4). Very high dust productivity, with $\mathrm{SI} \geq 0.7$, has 33 locations in the area within D $\leq$ $0.1^{\circ}$, and 42 and 46 within the $0.5^{\circ}$ and $1^{\circ}$, respectively. Highest dust productive potential, with $S I \geq 0.9^{\circ}$, have 27 locations in the environment within $\mathrm{D} \leq 0.1^{\circ}$, and 39 and 44 within the $0.5^{\circ}$ and $1^{\circ}$, respectively. One point has the highest SI value less than $0.5^{\circ}$ and 5 less than $0.9^{\circ}$ away when considering the largest environment of the HLD source mark. Three HLD source region marks are at the sea, which is why their source values are marked with -99 (undefined). In the south HLD region, 11 locations are considered (located in the area between $40^{\circ} \mathrm{S}$ and $60{ }^{\circ} \mathrm{S}$ ). Seven sources have very high dust productivity with SI $\geq 0.7$ at location of the HLD source marker, and 3 more have SI $\geq 0.7$ in the area of the source marker with $\mathrm{D} \leq 0.1^{\circ}$. Highest dust productive potential, with $\mathrm{SI} \geq 0.9^{\circ}$, have 7 sources in the area of the source marker with $\mathrm{D} \leq 0.1^{\circ}$, and three more in the area with $\mathrm{D} \leq 0.5^{\circ}$. As mentioned earlier, the source maximum and minimum intensities in these south HLD region differ much less than in north HLD region.

\subsection{Comparison of various regions}

For the HLD sources identified and included in our collection, the amount of available information varied from detailed

characterizations to the very first satellite observations, waiting to be complemented with measurement data. Model output of dust transport can provide valuable additional information. The sources are located in both the northern and southern high latitudes and include a variety of environments. Particle properties, such as particle size distributions, have been determined for only some of the identified HLD sources. For example, the many Iceland south coast sources of our study have not had any characterization done. Previous results on the known sources in the Iceland south coast region show that the particle size distributions greatly vary from one location to another, and no assumptions can be made based on characterization in one location. 
For Greenland, end of summer and autumn time (in October) are the seasons for dust activity. For example, on 19 October 2021, there was a significant dust activity in western Greenland, and several glacial valleys were emitting dust along the 700 $\mathrm{km}$ coast. During that dust event, there was a good Sentinel overpass showing a long narrow valley with a lot of haze(dust) in suspension (appearing as fuzziness in the image) (Gasso, 2021). As far as we know, there are no previous observations for this source. The Greenland west coast HLD sources (No. 53 - 58) are considered new and identified here using satellite observations. Currently, further knowledge on the recurrency or the area of the emission source is lacking. It is probable that these west coast of Greenland HLD sources have not been identified due to cloudy conditions most of the time. The representation of dust sources in modelling approaches require information on the geographic location. Soil characteristics and temporal changes. A detailed specification of the geographic distribution of potential dust sources and their physical (e.g., particle size distribution, optics) and mineralogical/chemical (mineral fractions, chemical composition, etc.) properties is the key to accurately parameterize the potential of dust emission in numerical dust models. There are various methods to detect new sources, and remote sensing is one of the most powerful tools, as demonstrated in the case of Iceland's southern coast, and Greenland's west and east coast.

The region of the central part of East European Plain is a potential aeolian dust source (Buggle et al., 2008), however they are currently lacking observations on dust lift and transport activity. Therefore, this region was not included in our collection of HLD sources. The gap for observations in the central part of East European Plain, and the potential future HLD source updates in this region, is filled here with unique data presented in the Supplement Figures S1-S4, including new previously unpublished results, on the partitioning of elements among the five particle-size fractions from the natural soils of a rural area located 100 $\mathrm{km}$ to the south-west from Moscow. Analyses of element distributions in various particle size fractions were performed to characterize topsoil horizons of a non-industrial (rural) area in the central part of European Russia (mixed forest zone). The study area $\left(55^{\circ} 12-13^{\prime} \mathrm{N}, 36^{\circ} 21-22^{\prime} \mathrm{E}\right)$ was in the southeastern part of the Smolensk-Moscow Upland (314 m a.s.1.), $100 \mathrm{~km}$ to the southwest from Moscow (Fig. S1). Geomorphologically, it belongs to a marginal area of the Middle Pleistocene (MIS 6) glaciation with moraine topography modified by post-glacial erosional and fluvial processes. The major soil reference group is Retisol developed on the loess-like loam. About $50 \%$ of the soils in the interfluve area were subjected to arable farming. The steepest relief elements in the study area such as sides of the river valleys or gullies represent erosional sites and are occupied by Regosols. A new previously unpublished independent dataset on 33 elements was obtained with a higher accuracy of ICP-MS/AES analyses (as compared to previously DC-ARC-AES data set of Samonova and Aseyeva, 2020).

Additional dust sources with massive dust storms causing severe traffic disruption have been documented from outside the dust belt in higher latitudes. These sources were mainly arable fields such as in Germany, Poland or US Montana and Washington state (Hojan et al., 2019). 


\subsection{A geological perspective on HLD sources and particle properties}

Dust sources involve very different formations and geological environments, each of them leaving its own imprint on the sediments. The geomorphological, sedimentological, petrological and geochemical study of the loose sedimentary formations in the source areas, thus, provides information on the origin and the provenance of dust when it is transported out or far from there. Such kind of studies, which are quite common for Saharan dust, are not so well established in the case of HLD sources.

810 The fact that these territories are not all easily accessible, and that the time of accessibility may not coincide with the period of dust production and/or dust emission, may be amongst the reasons for this missing source area characterization.

Geomorphological studies cover a wide range of subjects and topics from the characterization of specific dust sources (e.g., Arnalds et al., 2016; Bullard and Mockford, 2018; Bertran et al., 2021) to the analysis of processes (e.g., Bullard and Austin,

815 2011; Hedding et al., 2015; Wolfe, 2020) and landform evolution (Heindel et al., 2017). Sedimentological studies on dust sources focus on the morphological characteristics of the particles and on the textural details of the loose sediment formations. The size, shape and surface characteristics of the particles are, in fact, the result of morphogenetic processes and, as such, they say a lot about the source areas. Furthermore, the size and shape of the particles influence the lifting and transport capacity of the particles themselves, and finally the distance they can reach from their site of origin. This is the case of the studies of the properties of volcaniclastic dust sources in Iceland (e.g., Butwin et al., 2020; Richard-Thomas et al., 2021). From the petrological and geochemical point of view, the panorama is even wider, and even more varied. In fact, and apart from a few of them (e.g., Baratoux et al., 2011; Moroni et al., 2018), most studies on this context are not aimed at studying dust sources but comprise different targets involving the parental soils (e.g., Antcibor et al., 2014; Brédoire et al., al., 2015). These latter studies, though providing information on the (possible) source areas for dust, are not specifically aimed at the study of dust sources and are, thus, not functional to that purpose. Specific survey and sampling activities performed by a team of experts would be required to adequately address all aspects of dust sources and properties. In this way it would be possible to obtain a database as rich and articulated as possible on the physico-chemical properties of the particles within dust. This provides an ability to predict dust behavior within the aerosols, and to understand medium and long-range transport phenomena. A further aspect of interest regarding dust sources and properties is that of the evolution of the physico-chemical properties of the particles due to the lifting and transport mechanisms. To do this, the aerosols must be sampled in different places located at different distances from the source. However, this approach is complicated by the mixing of the air masses during transport, and it thus requires a deep investigation of air mass back trajectories. On the other hand, it can be very advantageous to treat the soils in the lab by re-suspending and sampling them by means of impactors at well-defined cut-off size ranges. Such kind of a work has been carried out on Australian soils and southern African soils (Giliet al, 2021) to study the sources of dust in Antarctica, and is currently underway for Iceland (Moroni, 2021, personal communication). 


\subsection{Local HLD sources versus long-range transported dust: discussing Svalbard and Antarctica}

The same areas of dust lifting can, in turn, be deposition sites, when particles leaving from their respective source regions are deposited there after prolonged transport pathways. The extent of the contribution of the two types of sources, local and longrange, may vary during the year depending on the type of atmospheric circulation and the state of the exposed surfaces, in particular the presence of bare deglaciated soils. This is the case of Svalbard, where the local sources of dust prevail over the long-range ones especially in summer and the contrary occurs in the rest of the year (Moroni et al., 2016; Spolaor et al., 2021). On the other hand, and always in Spitsbergen, the type of contributions, local and long-range, may also depend on the altitude due to the stratified structure of the lower atmosphere frequently found at high latitudes (e.g., Moroni et al., 2015; Kavan et al., 2020a).

Investigation of the physico-chemical properties is the key point to identify the source regions of dust and, possibly, to estimate their contributions in the different periods of the year. For example, in the case of Spitsbergen, the potential Source Contribution Function (PSCF) analysis of aerosol samples taken in Ny-Alesund made it possible to clearly identify four different HLD sources located in Eurasia, Greenland, Arctic-Alaska and Iceland (Crocchianti et al., 2021). On the other hand, chemical-mineralogical investigation and single particle analysis made it possible to recognize and estimate the contribution of Icelandic dust in Ny-Alesund (Moroni et al., 2018).

Kandler et al. (2020) collected dry dust deposition near source in northwest Africa, in Central Asia, and on Svalbard and at three locations of the African outflow regime and studied particle sizes and composition. Their results showed low temporal variation in estimated optical properties for each location, but considerable differences between the African, Central Asian, and Arctic regimes. An insignificant difference was found between the K-feldspar relative abundances, indicating comparable related ice-nucleation abilities. The mixing state between calcium and iron compounds was different for near source and transport regimes, potentially in part due to size sorting effects. As a result, in certain situations (high acid availability, limited time) atmospheric processing of the dust is expected to lead to less increased iron solubility for near-source dusts (for Central Asian ones) than for transported ones (in particular of Sahelian origin).

In the southern region, under certain meteorological conditions, dust from lower latitudes can be transported far toward polar regions. Such was the case when a major dust storm formed over Australia of 22 January 2020. Two days later, dust moved southward, covering a large part of Antarctica's Eastern coast. The RHMSS global version of DREAM model with incorporated ice nucleation parameterization due to dust (Nickovic et al., 2016) predicted formation of cold clouds over the Antarctic region, a pattern of the ice cloud phase also observed by the NASA satellite observations (Fig. 15). The simulation was performed as a part WMO SDS-WAS initiative to include dust impacts to high latitudes in its research agenda in order to better understand the role of mineral dust as a climate factor in the high latitudes. 

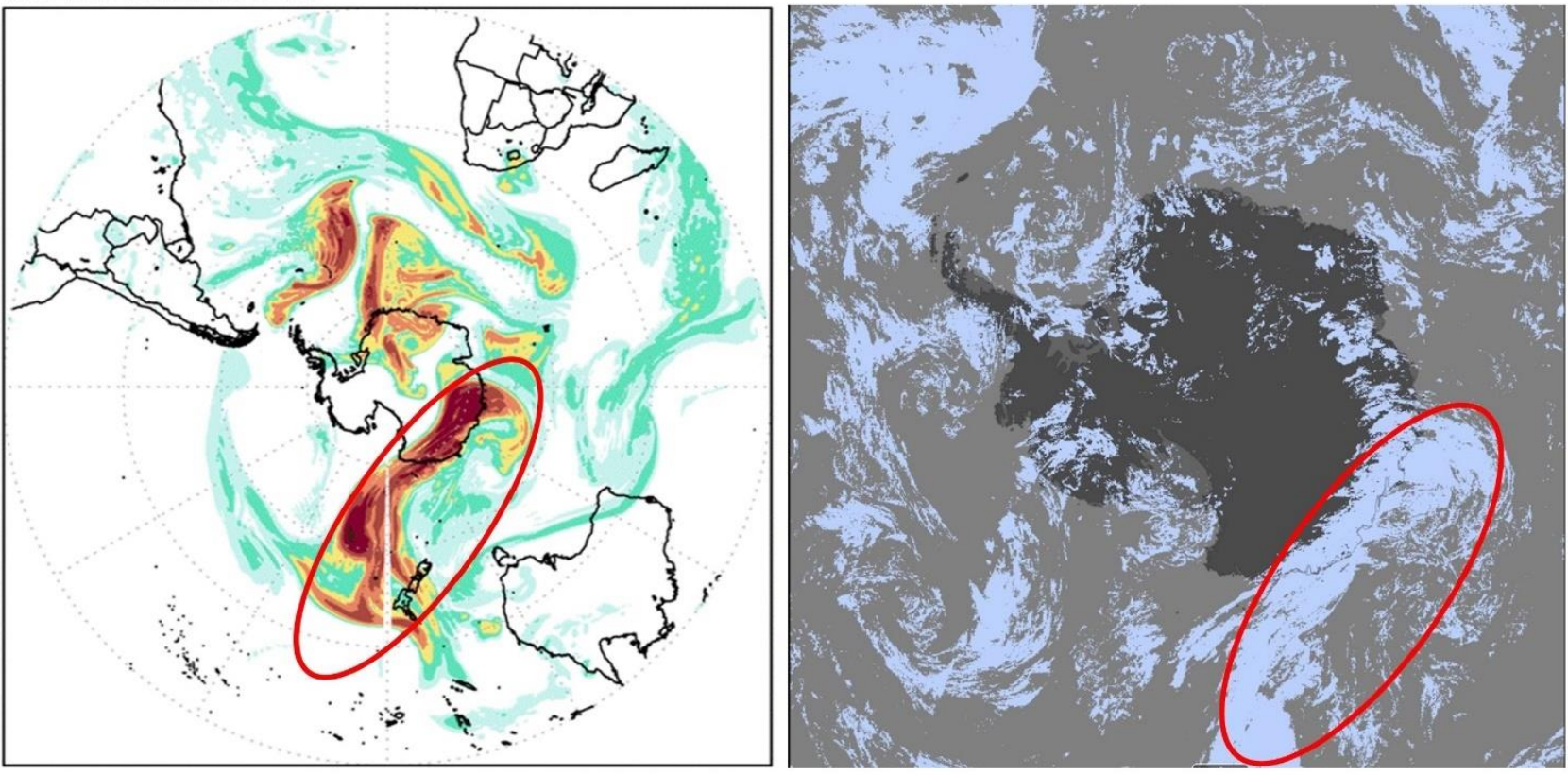

Figure 15. Global NMMB DREAM model experiments over Australia and South Pole: A) Model dust load 22 January 2020; B) Model $\log _{10}($ vertical load of ice nuclei number) (left) and NASA MODIS Ice cloud phase (right) for 24 January 2020.

875 The McMurdo Dry Valleys (MDV) have previously assumed to be a significant regional source of dust (e.g., Bullard 2016). New observations show that the Dry Valleys in fact don't contribute much dust. Instead, the debris covered surface of the McMurdo Ice shelf (sometime called the McMurdo debris bands) are the major source of dust. In this study, more details are provided to underline the importance and estimates of the size of the areas. The MDV (4 $\left.800 \mathrm{~km}^{2}\right)$ was here estimated to best fit Category 3. Despite active local aeolian sediment transport (many events occur each year) they are an insignificant source 
or exporter of dust regionally and therefore only have a small but poorly known climatic or environmental significance. The MDV are changing quickly with increased ablation, meltwater, and permafrost incision, so their importance in term of dust generation may change in the near future. The McMurdo Ice shelf 'debris bands' best fit Category 2. Although the source is only about $1500 \mathrm{~km}^{2}$, it is clearly the largest and most important dust source in the region. It is active with continuous supply of new sediment for export, exposed to frequent strong winds (many events during the year) even though few events have been documented. The aeolian sediment has an impact on sea ice albedo (not directly measured), marine sedimentation and contributes enough dissolved Fe to support potentially up to $15 \%$ of primary productivity in the SW Ross Sea.

Ice core studies from Antarctica Ice sheets show that Antarctica receives long range dust transport from Australia, South America, South Africa and New Zealand (e.g., Bullard 2016). However, several studies around coastal areas have shown that locally, Antarctic sourced dust accumulation rates are at least two orders of magnitude higher than that recorded from the polar plateau or from global dust models (Chewings et al 2014, Winton et al 2014).

\subsection{Impacts of HLD on clouds and climate feedbacks}

Clouds across the mid- and high latitudes are of first order importance for climate and HLDs may play a first order, but highly uncertain, role in defining their properties through the initiation of ice formation. Clouds frequently persist in a supercooled state, but the conversion of even a few droplets to ice crystals through heterogeneous freezing can lead to microphysical processes that dramatically reduce the liquid water content of a cloud, reducing its albedo and exposing the surface underneath (Murray 2021; Tan and Storelvmo, 2019). Only a small subset of atmospheric aerosol poses the capacity to nucleate ice and that concentrations of around only 1 INP per liter of air active at the cloud temperature can dramatically alter cloud albedo. In contrast, the concentration of aerosol particles capable of serving as cloud condensation nuclei (CCN) are orders of magnitude larger. Hence, dust particles in the high latitudes will rarely exist in high enough concentrations to dramatically impact cloud droplet numbers through providing additional CCN, but high latitude dusts have been shown to serve as effective INP in sufficient concentrations to have the potential to impact mixed-phase clouds (Sanchez-Marroquin, 2020). The role ice formation plays in climate projections depends on the location of the clouds. In the following paragraphs we discuss two distinct classes of cloud that may be influenced by HLD particles serving as INPs.

For boundary layer clouds over oceans between about $45-70^{\circ}$ the amount of ice versus supercooled water, and albedo, is critical for global climate (Vergara-Temprado et al., 2018; Bodas-Salcedo et al., 2014). These clouds are in locations where there is substantial solar insolation, and the contrast between a high albedo cloud and a dark ocean surface is large. Hence, these clouds are implicated in the cloud-phase feedback, where water replaces ice, increasing their albedo, as the world warms 910 with increased carbon dioxide (Storelvmo et al., 2015). The uncertainty of this feedback is very high, with the temperature rise associated with doubling of carbon dioxide increasing from around $4 \mathrm{~K}$ to well above $5 \mathrm{~K}$, by simply increasing the amount of 
supercooled water in clouds in the present-day climate (Frey and Kay, 2018). Hence, understanding the sources of icenucleating particles in the high latitudes, including HLDs, is therefore critical for understanding these climate relevant issues (Murray et al., 2021).

915

The second group of clouds are those which occur at high latitudes. For example, in the central Arctic mixed-phase clouds play a critical role in the local Arctic climate and the phenomenon known as Arctic amplification. In a corollary to the cloudphase feedback, replacement of ice with water leads to more downward longwave radiation, resulting in positive feedback (i.e., amplification) (Tan et al., 2019). Hence, the phase of clouds and therefore the INP population in clouds in the present

920 Arctic atmosphere are key for defining the strength of this feedback. In addition, any changes in INP population with a changing climate may also feedback on cloud properties (Murray et al., 2021).

Given the clear importance of INPs to defining cloud properties and climate feedbacks, surprisingly little is known about the ice nucleating properties of HLDs. Mineral dust is known to be one of the most important types of atmospheric INPs in clouds below about $-15{ }^{\circ} \mathrm{C}$ around the globe, both because of its relatively high ice-nucleating activity and its abundance in the atmosphere (Murray et al., 2012). A handful of papers have also identified HLDs to be significant contributors to the INP population in the Arctic (Irish et al., 2019; Sanchez-Marroquin, 2020; Tobo et al., 2019; Šantl-Temkiv et al., 2019). HLDs may differ in their ice-nucleating ability to LLDs for several reasons: Firstly, the HLDs from glacial valleys, for example, are often richer in primary minerals (olivenes, pyroxenes, feldspars and amphiboles) and less rich in clays in comparison to LLDs.

930 This is important, because K-rich feldspars are known for their exceptional ice-nucleating ability, whereas clays are much less active (Harrison et al., 2019; Atkinson, 2013). Secondly, the biggest LLD sources, like those in Africa, are abiotic (Price et al., 2018), whereas it has been found that HLDs can be associated with highly effective biogenic ice-nucleating material (Tobo et al., 2019; Šantl-Temkiv et al., 2019). The inclusion of biological ice-nucleating material, which can be ice-active at temperatures much higher than $-15{ }^{\circ} \mathrm{C}$ may mean that these dust sources have a disproportionately greater impact on cloud glaciation and climate than their low latitude counterparts. A great deal more research is needed to define and understand the ice nucleating ability of these HLD sources.

\subsection{Impacts of HLD on atmospheric chemistry}

7.6 Impacts of HLD on atmospheric chemistry

940 A specific HLD, Icelandic dust, is resuspended constantly from the deserts, and it is of volcanic origin. With respect to atmospheric chemistry the biggest impact comes from the particles that are in the 0.002 to $10 \mu \mathrm{m}$ range, as they can be carried over larger distances (Finlayson-Pitts, 1999). Atmospheric impact of the Icelandic dust in the troposphere is not as addressed as the impact of desert dust. This HLD is very likely a long-range transporting carrier for many species adsorbed on its surface. 
It can act as a sink of trace gases and a subsequent platform for transferring taken up species. Along transport, adsorbed species

may undergo different heterogeneous reactions that can lead to secondary compound formation. Such processes can influence the reactivity and the balance of atmospheric species. As a result of heterogeneous interactions, optical, hygroscopic, and more generally physicochemical properties of the HLD themselves can be changed due to surface processes implying atmospheric trace gases (Usher et al., 2003). Depending on the nature of atmospheric trace gases interacting with HLD, the consequences can be highly different. This section aims at illustrating the diversity of interactions between HLD and atmospheric trace gases, to emphasize the various impacts of these aerosols on atmospheric physics and chemistry. In the case of ozone, if the direct heterogeneous interaction with dust does not play a major role in the atmospheric concentration decrease of the primary compound, surface processes are triggered, affecting the atmospheric budget of ozone. In the case of $\mathrm{NO}_{2}$, heterogeneous processes on dust can significantly lead to the formation of HONO species, with direct impacts on gas phase atmospheric reactivity. In the case of $\mathrm{SO}_{2}$, beyond a complex reaction pathway, the heterogeneous process dually affects the budget of the taken-up species as well as the chemical and physical properties of the dust surface.

If the heterogeneous reaction of $\mathrm{NO}_{2}$ on various types of atmospheric particles, e.g., salts, soot, mineral dust and proxies, was addressed in the literature (George et al. 2016), the interaction of $\mathrm{NO}_{2}$ with volcanic particles, typical HLD, under atmospheric conditions has only been studied by Romanias et al. (2020). They explore the possible formation of short lifetime key atmospheric species, considered as a trigger of numerous atmospheric processes: HONO, a precursor of OH radicals in the atmosphere. To that end, $\mathrm{NO}_{2}$ uptake on Icelandic $\mathrm{HLD}$ is explored under various and contrasted atmospheric conditions. Despite the relatively close volcanic regions where the selected samples originate, uptake coefficients of $\mathrm{NO}_{2}$ contrasted significantly with the dust location due to magmatic and morphological differences between samples. This point confirms that in terms of atmospheric heterogeneous chemistry, sample behavior can significantly contrast from a class of dust to another, physical and chemical characterizations of the samples remain key intrinsic descriptors. Nonetheless, volcanic dust appear as effective $\mathrm{NO}_{2}$ scavengers from atmosphere. The interaction of $\mathrm{NO}_{2}$ with that HLD is evidenced to be a source of $\mathrm{NO}$ and more interestingly HONO, with kinetics and formation yields highly dependent on relative humidity. Higher HONO formation yields on volcanic samples are observed for RH values exceeding $30 \% \mathrm{RH}$. Heterogeneous formation of $\mathrm{HONO}$ from $\mathrm{NO}_{2}$ interaction with Icelandic dust is estimated to be atmospherically significant under volcanic eruptions or, more frequent in Iceland, during typical volcanic dust storms, leading to $\mathrm{HONO}$ formation rates up to $10 \mathrm{pptV} / \mathrm{hr}$ that can significantly influence the oxidative capacity of the regional atmosphere. The experimental determination of $\mathrm{NO}_{2}$ uptake coefficient $\gamma$ allows including such processes in atmospheric modelling improving their representativeness.

A transient uptake of $\mathrm{SO}_{2}$, i.e. important uptake of $\mathrm{SO}_{2}$ initially that progressively is reduced leading to low steady state uptake 975 coefficients of $\mathrm{SO}_{2}$ after several hours of exposure in the range of 10-9 to 10-8, and the surface coverages were in the range of 1014 molecule cm-2 or 1016 molecule cm-2 using the total surface area or the geometric surface area of aerosols respectively (Urupina et al., 2019). Zhu et al. (2020) estimated that around $43 \%$ more volcanic sulfur is removed from the stratosphere 
within months due to $\mathrm{SO}_{2}$ heterogeneous chemistry on volcanic particles than without. Concomitantly with $\mathrm{SO}_{2}$ uptake, both sulfites and sulfates are monitored on the surface of volcanic dust, with sulfates being the final oxidation product, attesting of the conversion of $\mathrm{SO}_{2}$ to sulfites as evidenced experimentally using lab scale but atmospheric relevant experimental setups (Urupina et al, 2019). This allows providing original insights in the kinetics and mechanism of $\mathrm{SO}_{2}$ uptake and transformation on volcanic material under simulated atmospheric conditions. To that regards, it brings an accurate perspective on $\mathrm{SO}_{2}$ heterogeneous sinks in the atmosphere on the HLD surface. The model simulations of Zhu et al. (2020), suggested that the transformation of $\mathrm{SO}_{2}$ on such particles plays a key role in the sulfate content in the stratosphere. Interestingly, this transformation and accumulation of sulfates on the surface of particles could turn the unreactive ozone material to reactive, especially in the stratosphere, where volcanic particles have long lifetimes.

The case of $\mathrm{SO}_{2}$ uptake points at the ageing of the HLD surface with subsequent impacts on their chemical and physical properties such as hygroscopicity and optical properties. Changing in hygroscopic properties can correlate with a variable behavior of HLD to act as cloud and/or ice nucleating particles, depending on their interactions with atmospheric gases. Similarly, a high surface coverage of sulfate and sulfuric acid as reported by Urupina et al. (2019), for volcanic dusts, questions the variability of HLD refractive index and the impact on remote sensing of fresh vs. aged dust.

\subsection{Impacts of HLD on the marine environment}

995 Mineral dust is a source of essential nutrients such as phosphorus (P), iron (Fe) and nitrogen $(\mathrm{N})$ to the ocean ecosystems. Dust deposition onto the ocean's surface has the potential to stimulate primary productivity and consequently enhance carbon uptake, which indirectly affects the climate. The extent of these impacts primarily depends on the dust deposition fluxes and its chemical properties, and the nutrients (co)limitations patterns in the ocean waters (e.g., Kanakidou et al., 2018; Mahowald et al., 2010; Shi et al., 2012; Stockdale et al., 2016).

Sub-Arctic oceans are either Fe limited or seasonally Fe limited. Fe limits primary productivity in the sub-Arctic Pacific Ocean (Martin and Fitzwater, 1988). The atmospheric Fe deposition in the Gulf of Alaska is dominated by dust transported from glacial sediments from the Gulf of Alaska coastline (Crusius et al., 2011), with relatively high fractional Fe solubility, around 1.4\% (Schroth et al., 2017). Although the upwelling of deep water is the major source of dissolved Fe, the atmospheric flux of

dissolved Fe to the surface water of the Gulf of Alaska is comparable to the Fe flux from eddies of coastal origin (Crusius et al., 2011). The magnitude of the deposition of glacial dust to the Gulf of Alaska varies significantly depending on the regional weather conditions, but the extent of its impacts is still unclear (Schroth et al., 2017). Currently, the spatial resolution of global dust models is too low to accurately reproduce Alaskan dust flux which is generated by anomalous offshore winds and channelled through mountains (Crusius, 2021). Recently, Crusius (2021) determined dissolved Fe inventories based on time 
1010 series of dissolved $\mathrm{Fe}$ and particulate Fe concentrations from the Ocean Station Papa in the central Gulf of Alaska, including measurements from September 1997 to February 1999. The analysis showed 33\%-70\% increases in dissolved Fe inventories between September and February of successive years, which was possibly linked to dust fluxes from the Alaskan coastline, which are known to occur mostly in autumn (Crusius et al., 2011; Schroth et al., 2017). These new results support the importance of the contribution of atmospheric Fe, although more work is needed to confirm the sources of dissolved Fe to the

1015 Gulf of Alaska.

The sub-Arctic North Atlantic Ocean is seasonally Fe limited (Nielsdottir et al., 2009; Ryan-Keogh et al., 2013). Natural dust from Iceland is a major contribution to the atmospheric dust deposition to the North Atlantic Ocean (Bullard, 2016). Icelandic dust originates from volcanic sediments and has a relatively high total Fe content, about 10 \% (e.g., Arnalds et al., 2014, Baldo

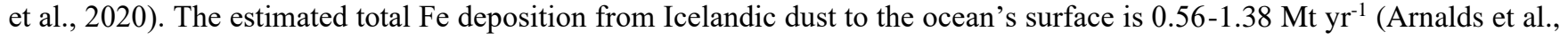
2014). The initial Fe solubility observed in dust samples from Icelandic dust hotspots is from 0.08 to $0.6 \%$, which is comparable to that of mineral dust from low latitude regions such as northern Africa, while the fractional Fe solubility at low pH (i.e., 2) is significantly higher than typical low latitude dust (up to 30\%) (Baldo et al., 2020). Achterberg et al. (2018) argued that deepwater mixing is the dominant source of Fe to the surface water of the sub-Arctic North Atlantic Ocean, which is up to 10

1025 times higher than the Fe supply by atmospheric Fe deposition. However, during the 2010 eruption of the Icelandic volcano Eyjafjallajökull, Achterberg et al. (2013) observed elevated dissolved Fe concentration and nitrate depletion in the Iceland Basin, followed by an early spring bloom. This suggests that Icelandic dust has the potential to impact the Fe biogeochemistry and primary productivity in the surface ocean.

1030 Although nitrate is the primary limiting nutrient in the Arctic Ocean (Popova et al., 2010), Fe becomes limiting in some are as (Taylor et al., 2013). Local dust sources including Eurasia, Greenland, Iceland and North America are the major contributors to the atmospheric dust deposition in the Arctic region (Groot Zwaaftink et al., 2016). Gao et al. (2019) measured 2-16\% fractional Fe solubility in dust aerosols over the Arctic Ocean, resulting from the interaction of regionally emitted dust with organic ligands in the Arctic atmosphere. This suggests that high latitude dust in the Arctic can significantly contribute to the 1035 atmospheric flux of dissolved Fe to the Arctic Ocean.

The Southern Ocean is known to be Fe limited (Moore et al., 2013). Major atmospheric dust sources include for example Australia, southern South America, and southern Africa (e.g., Ito and Kok, 2017). Contribution from local sources in Antarctica is also observed (e.g., Chewings et al., 2014; Winton et al., 2014; Winton et al., 2016). Winton et al. (2016) reported a 1040 background fractional Fe solubility from mineral dust sources of $0.7 \%$. Even though the upwelling of deep water is the major source of dissolved Fe, the atmospheric deposition of dissolved Fe can locally contribute to the phytoplankton bloom (Winton et al., 2014), while there is evidence that increased dust flux enhanced primary production in the Southern Ocean in the last glacial age (Martínez-García et al., 2014). The Ross Sea is a continental shelf region around Antarctica, and it is a highly 
biologically productive area in the Southern Ocean, which has important implications for global carbon sequestration (e.g., Arrigo et al., 2008; Arrigo and Van Dijken, 2007). In the Ross Sea, additional Fe supply is required to sustain the intense phytoplankton bloom during the austral summer (Tagliabue and Arrigo, 2005). Measurements conducted on snow pits and surface snow samples showed that local Antarctic dust does contribute to Fe deposition, which is however only a minor component of the total Fe supply to the Ross Sea, with most being supplied by upwelling of deep water (Winton et al., 2014; Winton et al., 2016).

In the Polar regions, atmospheric dust is mostly delivered to the sea-ice, where melting/freezing cycles (ice processing) can enhance the formation of relatively more soluble phases of Fe oxide-hydroxide minerals such as ferrihydrite, which has the potential to increase the flux of atmospheric dissolved Fe to the ocean (Raiswell et al., 2016).

\subsection{HLD impacts on cryosphere and cryosphere-atmosphere feedbacks}

1055 Cryosphere is the frozen water part of the Earth system, including sea, lake and river ice, snow cover, glaciers and ice caps, ice sheet, and permafrost and frozen ground. These components play an important role in the Earth's climate (IPCC, 2019). It has been shown that temperatures in fragile areas, such as the pristine polar regions, have been increasing at twice the global average, and the highest increase in the temperature of the coldest days, up to three times the rate of global warming, is projected for the Arctic (IPCC, 2021). Warming in vulnerable cold climate land areas causes glacier retreat, permafrost thaw, and decrease in snow cover extent (IPCC, 2019). Consequently, potential HLD sources, such as glacial sediments, can increase (e.g., Nagatsuka et al. 2021). When dust is long-range transported and wet or dry deposited, or windblown from local dust sources, on a glacier surface, the ice and snow albedo decreases and influences glacier melt rates (e.g., Boy et al., 2019) via the positive ice-albedo feedback mechanism (AMAP 2015; Flanner et al., 2007; Gardner and Sharp, 2010; IPCC, 2019). Cryospheric melt processes are controlled by many environmental factors (IPCC, 2019), such as solar irradiance, ambient temperature, and precipitation (e.g., Meinander et al., 2013, 2014; Mori et al. 2019). Kylling et al. (2018) used dust load estimates from Groot Zwaaftink et al. (2016) (using low latitude dust complex refractive index for high latitude dust) to quantify the mineral dust instantaneous radiative forcing (IRF) in the Arctic for the year 2012. They found that annual-mean top of the atmosphere IRF $\left(0.225 \mathrm{~W} / \mathrm{m}^{2}\right)$ had largest contributions from dust transported from Asia south of $60{ }^{\circ} \mathrm{N}$ and Africa, and high-latitude $\left(>60^{\circ} \mathrm{N}\right)$ dust sources contributed about $39 \%$ to top of the atmosphere IRF. However, HLD had larger impact

1070 (1 to 2 orders of magnitude) on IRF per emitted kilogram of dust than low-latitude sources. They also reported that mineral dust deposited on snow accounted for nearly all the bottom of the atmosphere IRF $\left(0.135 \mathrm{~W} / \mathrm{m}^{2}\right)$, with more than half caused by dust from high-latitude sources.

For snow and ice (glacier) surface radiation balance, the net energy flux $E_{N}$ is due to differences between downward $(\downarrow)$ and upward $(\uparrow$ ) non-thermal shortwave (SW) and thermal longwave (LW) radiative fluxes and is most critically influenced by the 
surface characteristics of the bihemispherical reflectance (BHR), i.e., albedo (Manninen et al., 2021). Therefore, melt is also controlled by dark impurities in snow and ice (IPCC, 2019). Black carbon (BC) is the best studied climatically significant dark light absorbing aerosol particle in snow (e.g., Bond et al., 2013; Dang et al., 2017; Evangeliou et al., 2018; Flanner et al., 2007; Forsström et al., 2013; Mori et al. 2019; Meinander et al., 2020a,b), and radiation-transfer (RT) calculations indicate that seemingly small amounts of black carbon (BC) in snow, of the order of 10-100 parts per billion by mass (ppb), decrease its albedo by 1-5\% (Hadley and Kirchtetter, 2012), and BC has been shown to enhance snow melt (AMAP, 2015; Bond et al., 2013; IPCC, 2019). Other light absorbing particles include organic carbon (which includes brown carbon) and dust. In addition, blooms of pigmented glacier ice algae can lower ice albedo and accelerate surface melting (McCutcheon et al., 2021), who also have shown a direct link between mineral phosphorus in surface ice and glacier ice algae biomass. They say that nutrients from mineral dust likely drive glacier ice algal growth, and thereby identify mineral dust as a secondary control on ice sheet melting. Some of the Icelandic dust sources have particles that are almost as black as black carbon by the reflectivity properties when measured as bulk material or on snow and ice surfaces (Peltoniemi et al., 2015). On the contrary to black carbon, Icelandic dust has been shown to melt snow quicker in small amounts, and to insulate and prevent melt in larger amounts (e.g., Dragosics et al., 2015; Möller et al., 2016; Boy et al., 2019). Changes related to permafrost thaw and snow and ice melt, including disappearance of glaciers and sea level rise as well as shortage in drinking water, are among the most serious global threats (IPCC, 2019). Water availability is a key issue in regions where agricultural crops are most dependent on snowmelt water resources (Qin et al., 2020). Snow is also essential in the catchment areas, i.e., in areas that supply watercourses, and for many snow-dependent organisms, including plants, animals, and microbes (Zhu et al., 2019). Melt can also run hydroelectric power plants that supply electricity (e.g., Lappalainen et al., 2021). This highlights the importance of investigations and continuous assessment of the temporal and spatial importance and contribution of different light absorbing impurities in enhancing or initiating cryospheric melt in the changing climate.

\section{Conclusions and outlook}

We identified 64 new HLD sources and their observations and source characteristics. We estimated that in the high latitudes, the land area with higher ( $\mathrm{SI} \geq 0.5)$, very high $(\mathrm{SI} \geq 0.7)$ and the highest potential $(\mathrm{SI} \geq 0.9)$ for dust emission cover $>1670000$ $1100 \mathrm{~km}^{2},>560000 \mathrm{~km}^{2}$, and $>240000 \mathrm{~km}^{2}$, respectively. This agrees with the first HLD sources estimate of an area >500 $000 \mathrm{~km}{ }^{2}$ by Bullard et al. (2016). It indicates that the first HLD source estimate included mainly the sources with very high potential for dust emission classified in this study. Our study shows that active sources cover a significantly larger area, which is also confirmed by more than 60 new HLD sources with evidence on their dust activity, not only limited to dry areas. The potential HLD emission areas need proof of observed and identified HLD emission sources. Our update provides crucially needed 1105 information on the extent of active HLD sources and their locations. Active HLD sources serve as important sources of aerosols with both direct and indirect impacts on climate and environment in remote regions, which are often poorly understood and predicted. HLD is likely a significant source of atmospheric iron deposition in the sub-Arctic and Arctic Ocean, and in the 
Southern Ocean, encircling Antarctica. More work is needed to quantify the deposition flux of HLD and nutrient (Fe, P, N, trace metals such as Co) content and solubility, which can then be fed to ocean biogeochemical models to quantify their impact on ocean biogeochemistry. HLD is also an active ice-nucleating particle changing cloud properties and it has severe impacts when deposited within cryosphere. More studies are however needed for HLD from different regions. For example Northern Asia HLD sources are assumed to be many, but difficult to access and gain information. This points to the following main action items for monitoring dust in high latitudes:

- Firstly, the work on HLD sources needs a multidisciplinary combination of field, laboratory and experimental work, remote sensing and modeling. Increase in observational and modeling studies results in better HLD monitoring and predicting.

- Secondly, the activity of the currently identified active sources should be followed and re-evaluated in the coming years and decades.

- Thirdly, research gaps and future research directions essentially include finding, identifying and characterizing of new dust sources, and as soon as there is first evidence for finding a new HLD source, it should be included in the list of dust sources, subject to further studies.

- Fourthly, the role of different types of road dust in the Arctic could be separately assessed using a common methodology.

Namely, in Arctic communities, road dust as a signature of non-exhaust traffic dust formed via abrasion and wear of pavement,

1125 traction control materials, vehicle brakes and tyres, is a common concern (e.g., Kupiainen et al., 2016; Nordic Council of Ministers 2017). In this paper, we excluded this type of road dust, and only included significant anthropogenic road dust sources where the unpaved road serves as a notable source of dust itself. Unpaved areas of parking lots or storage areas and road shoulders or roadside lawn dust and the effect of winter could be considered, too. In winter, during the cold and wet weather conditions, dust accumulates in snow and ice, and in the humid road surface texture. As snow and ice melt and street 1130 surfaces dry up in spring, high amounts of dust become available for suspension. For example, in Finland, located north of $60^{\circ} \mathrm{N}$, a major anthropogenic dust source is due to sand and gravel uptake for building purposes from ice age formed ridges. These non-renewable ridges cover an area of 1.5 million ha, and it has been estimated that annually since 1960, continuously each year, approximately 40 million tons/year have been utilized (Fig, 211 of Wahlström et al., 1996). The se used open sand areas are visible in aircraft photos and satellite images. Another health significant anthropogenic spring-time dust source is 1135 wintertime pavement traction sanding (Kuhns et al., 2010; Kupiainen 2007; Stojiljkovic et al. 2019). These spring-time dust events are annual but local throughout the country. As a comparison, the Moscow metropolitan area $\left(55^{\circ} 45^{\prime} \mathrm{N}, 37^{\circ} 37^{\prime} \mathrm{E}\right)$ is one of the most significant sources of dust at latitudes above $50^{\circ} \mathrm{N}$, where the dust impact of Moscow can extend over several hundred kilometers (Adzhiev et al., 2017). The road dust in Moscow is mainly generated on paved roads, but roadside soils also contribute to the dust load (Kasimov et al., 2020). Most often, unsealed soils are covered with lawns, also widespread in 1140 parks, recreational zones, and within industrial zones, which are characterized by heavy pollution, mixed upper horizon, and a high degree of soil cover heterogeneity. 
In summary, establishing continuous monitoring on HLD sources and their future changes are a key to understand the climatic and environmental effects in the high latitudes and especially in the Arctic. Climate change causes permafrost thaw, decrease of snow cover duration, retrieval of glaciers, increase of drought and heat waves intensity and frequency, which all lead to the increasing frequency of topsoil conditions favorable for dust emission (increasing of soil exposure to wind erosion), and thereby increasing probability for dust storms. Although dust originates from natural soils, these sources are also influenced by human activities, e.g., when deforestation and land management in cold regions leads to the ecosystem collapse and desertification (Prospero et al., 2012; Arnalds, 2015). Wildfires, whether natural or anthropogenic, can also result in creating new dust sources (Miller et al., 2012). Hence, human actions can influence HLD and its effects both positively and negatively. To understand and assess the temporal activity changes in HLD sources and the multiple impacts of the high latitude dust on the Earth systems over time, continuous monitoring and regular updates on location, area, particle properties and activity of current and new HLD sources is needed. The new observations presented in this study essentially improved the representation of HLD sources for various approaches and applications related to the observed current, previous, and future environmental changes at high latitudes.

Competing interests. The authors declare that they have no conflict of interest.

Special issue statement. This article is part of the special issue "Arctic climate, air quality, and health impacts from shortlived climate forcers (SLCFs): contributions from the AMAP Expert Group (ACP/BG inter-journal SI)”. It is not associated with a conference.

\section{Acknowledgements}

This paper was developed as part of the Arctic Monitoring and Assessment Programme (AMAP), AMAP 2021 assessment: Arctic climate, air quality, and health impacts from short-lived climate forcers (SLCFs). Kaarle Kupiainen, Johanna Ikävalko, Terhikki Manninen, Hanna K. Lappalainen, and Antti Kulmala are gratefully acknowledged. Help of the staff of the stations 1165 is highly appreciated.

\section{Financial support}

This research has been supported by the Ministry for Foreign Affairs of Finland (IBA-project No. PC0TQ4BT-25). The study of dust composition in Moscow and Tiksi was supported by the Russian Science Foundation (No. 19-77-30004). Firn cores

1170 collection on southern Spitsbergen, Svalbard has been co-funded by Research Council of Norway, Arctic Field Grant 2018 (No. 282538), funds of the Leading National Research Centre (KNOW) received by the Centre for Polar Studies of the University of Silesia and, statutory activities No. 3841/E-41/S/2018 of the Ministry of Science and Higher Education of Poland. 
The Czech Science Foundation project GC20-20240S and Ministry of Education, Youth and Sports of the Czech Republic projects No. LM2015078 and CZ.02.1.01/0.0/0.0/16_013/0001708 are acknowledged. The support of the EPOS-PL project

(No. POIR.04.02.00-14-A003/16), co-financed by the European Union from the funds of the European Regional Development Fund (ERDF) to the laboratory facilities at IG PAS used in the study is also acknowledged. European Union COST Action InDust is acknowledged. The preparation of this paper was in part funded by the Icelandic Research Fund (Rannis) Grant No. 207057-051. O. Meinander acknowledges funding from the Academy of Finland (ACCC Flagship funding grant No. 337552), H2020 EU-Interact (No. 730938), International Arctic Science Committee (IASC Cross-Cutting grant) and Ministry for 1180 Foreign Affairs of Finland (IBA-project No. PC0TQ4BT-20). D. Frolov is thankful to Lomonosov Moscow State University (state topic "Danger and risk of natural processes and phenomena" No. 121051300175-4). K. Kandler was funded by the Deutsche Forschungsgemeinschaft (DFG, German Research Foundation No. 264912134, 416816480, 417012665N). N. Kasimov and E. Aseyeva gratefully acknowledge the Russian Science Foundation (No. 19-77-30004). J. King acknowledges finding by NSERC Discovery 2016-05417, CFI 36564, and the CMN RES00044975.B. Murray, A. Sanchez-Marroquin and

1185 S. Barr thank the European Research Council (648661 MarineIce) and the Natural Environment Research Council (NE/T00648X/1; NE/R006687/1). O. Möhler and N.S. Umo acknowledge the funding support from Helmholtz Association of German Research Centres through its 'Changing Earth — Sustaining our Future' Programme. O. Popovicheva acknowledges funding from RFFR project 18-60084. K. Ranjbar and N.T. O'Neill acknowledge the PAHA project (NSERC-CCAR program; RGPCC-433842-2012), the SACIA project (CSA-ESSDA program; 16UASACIA) and the NSERC DG grants of O'Neill (RGPIN-05002-2014). I. Semenkov, O.Popovicheva and N.Kasimov acknowledge funding from the M.V.Lomonosov Moscow State University (the Interdisciplinary Scientific and Educational School «Future Planet and Global Environmental Change» and project No. 121051400083-1). Z. Shi and C. Baldo are funded by UK Natural Environment Research Council (NE/L002493/1; NE/S00579X/1).

\section{Supplement}

The supplement related to this article is available online at:

\section{Data availability}

Data are mostly included in this article or else available on request via personal communication.

\section{Author contribution}

The paper was initiated and lead by O. Meinander; P. Dagsson-Waldhauserova co-coordinated and edited. HLD SI and area calculations were by A. Vukovic and B. Cvetkovic. Identification of new HLD sources was as follows. Alaska, Canada: S. Barr, P. Dagsson-Waldhauserova, P., S. Gasso, J. King, B.J. Murray, J.B. McQuaid, N.T. O’Neill, K. Ranjbar. Antarctica: P. 1205 Dagsson-Waldhauserova, J. Kavan, K. Láska, O. Meinander, E. Shevnina. Denmark and Sweden: O. Meinander. Greenland: A. Baklanov, L.G. Benning, P. Dagsson-Waldhauserova, S. Gasso. Iceland: T. Thorsteinsson. Russia: P. Amosov, A. 
https://doi.org/10.5194/acp-2021-963

Preprint. Discussion started: 17 December 2021

(c) Author(s) 2021. CC BY 4.0 License.

(c) (i)

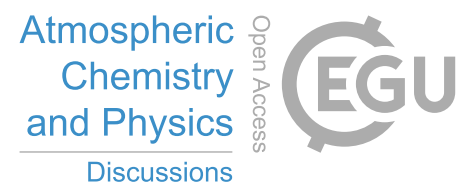

Baklanov, P. Enchilik, T. Koroleva, V. Krupskaya, O. Popovicheva, A. Sharapova, I. Semenkov, M. Timofeev. Svalbard: B. Barzycka, M. Kusiak, M. Laska, M. Lewandowski, B. Luks, A. Nawrot, T. Werner, K. Kandler, N. S. Umo, B.J. Murray, J.B. McQuaid, A. Sánchez-Marroquín, O. Möhler. South America, Argentina, and Patagonia: S. Gasso. DREAM model: B. 1210 Cvetkovic, S. Nickovic. SILAM model: A. Uppstu and M. Sofiev. All authors contributed significantly to the preparation of the manuscript. 


\section{References}

Achterberg, E. P., Moore, C. M., Henson, S. A., Steigenberger, S., Stohl, A., Eckhardt, S., Avendano, L. C., Cassidy, M., Hembury, D., Klar, J. K., Lucas, M. I., Macey, A. I., Marsay, C. M., and Ryan-Keogh, T. J.: Natural iron fertilization by the

Eyjafjallajokull volcanic eruption, Geophysical Research Letters, 40, 921-926, doi: 10.1002/grl.50221, 2013.

Achterberg, E. P., Steigenberger, S., Marsay, C. M., LeMoigne, F. A. C., Painter, S. C., Baker, A. R., Connelly, D. P., Moore, C. M., Tagliabue, A., and Tanhua, T.: Iron Biogeochemistry in the High Latitude North Atlantic Ocean, Scientific Reports, 8, doi: 10.1038/s41598-018-19472-1, 2018.

Adzhiev, A. H., Bartalyov, S. A., Bekkiev, M. Y., Biryukov, M. V., Biryukova, O. N., Bityukova, V. R., Bobylev, S. N., Bogdanova, M. D., Bozhilina, E. A., Bronnikova, V. K., et al.: Ecological atlas of Russia, Feoria, Moscow, 510 pp., 2017.

AMAP: Black Carbon and Ozone as Arctic Climate Forcers. Arctic Monitoring and Assessment Programme (AMAP), Oslo, $116,2015$.

Amino, T., Y. Iizuka, S. Matoba, R. Shimada, N. Oshima, T. Suzuki, T. Ando, T. Aoki, and K. Fujita: Increasing dust emission from ice free terrain in southeastern Greenland since 2000, Polar Science, 100599, doi:https://doi.org/10.1016/j.polar.2020.100599, 2020.

Amosov P.V. and Baklanov A.A.: Assessment of dusting intensity on ANOF-2 tailing by using a Westphal D.L. dependency // Proceedings of the X International Symposium on Recycling Technologies and Sustainable Development, 4-7 November 2015, Bor, Serbia. - Bor: University of Belgrade, Technical Faculty, 2015. - P. 39-43, 2015.

1240 Anderson, N. J., J. E. Saros, J. E. Bullard, S. M. P. Cahoon, S. McGowan, E. A. Bagshaw, C. D. Barry, R. Bindler, B. T. Burpee, J. L. Carrivick, et al.: The Arctic in the twenty-first century: Changing biogeochemical linkages across a paraglacial landscape of Greenland. BioScience, 67:118-133. doi:10.1093/biosci/biw158, 2017.

Antcibor I, Eschenbach A, Zubrzycki S, Kutzbach L et al: Trace metal distribution in pristine permafrost-affected soils of the 1245 Lena River delta and its hinterland, northern Siberia, Russia. Biogeosciences 11:1-15, 2014.

Arnalds, O., Thorarinsdottir, E.F., Thorsson, J., Dagsson-Waldhauserova, P., Agustsdottir, A.M.: An extreme wind erosion event of the fresh Eyjafjallajokull 2010 volcanic ash. Nature Scientific Reports 3, 1257, 2013. 
1250 Arnalds, O., Olafsson, H., and Dagsson-Waldhauserova, P.: Quantification of iron-rich volcanogenic dust emissions and deposition over the ocean from Icelandic dust sources, Biogeosciences, 11, 6623-6632, doi: 10.5194/bg-11-6623-2014, 2014.

Arnalds O., Pavla Dagsson-Waldhauserova, Haraldur Olafsson, The Icelandic volcanic aeolian environment: Processes and impacts - A review, Aeolian Research, 10.1016/j.aeolia.2016.01.004, 20, (176-195), 2016.

Arrigo, K. R., and Van Dijken, G. L.: Interannual variation in air-sea CO2 flux in the Ross Sea, Antarctica: A model analysis, Journal of Geophysical Research-Oceans, 112, doi: 10.1029/2006jc003492, 2007.

Arrigo, K. R., van Dijken, G., and Long, M.: Coastal Southern Ocean: A strong anthropogenic CO2 sink, Geophysical Research 1260 Letters, 35, doi: 10.1029/2008g1035624, 2008.

Atkins, C.B., and Dunbar, G. B. Aeolian sediment flux from sea ice into Southern McMurdo Sound, Antarctica. Global and Planetary Change: 69, 133-141, 2009.

1265 Atkinson, J. D., B. J. Murray, M. T. Woodhouse, T. F. Whale, K. J. Baustian, K. S. Carslaw, S. Dobbie, D. O'Sullivan, and T. L. Malkin, The importance of feldspar for ice nucleation by mineral dust in mixed-phase clouds, Nature, 498,7454, 355-358, doi:10.1038/nature12278, 2013.

Aun, M., Lakkala, K., Sanchez,R., Asmi, E., Nollas, F., Meinander, O., Sogacheva, L., De Bock, V., Arola, A., de Leeuw, 1270 G., Aaltonen, V., Bolsée, D., Cizkova, K, Mangold, A., Metelka,L., Jakobson, E., Svendby,T., Gillotay, D., and Van Opstal, B.: Solar UV radiation measurements in Marambio, Antarctica, during years 2017-2019, Atmos. Chem. Phys., 20, 6037-6054, doi:10.5194/acp-20-6037-2020, 2020.

Ayling, B. F., and H. A. McGowan: Niveo-eolian sediment deposits in coastal South Victoria Land, Antarctica: Indicators of 1275 regional variability in weather and climate, Arc. Antarct. Alp. Res., 38(3), 313-324, 2006.

Bachelder, J., Cadieux, M., Liu-Kang, C., Lambert, P., Filoche, A., Aparecida Galhardi, J., Hadioui, M., Chaput, A., BastienThibault, M.-P., Wilkinson, K.J., King, J., and Hayes, P.J.: Chemical and microphysical properties of wind-blown dust near an actively retreating glacier in Yukon, Canada. Aerosol Science and Technology 54:1, 2-20, DOI: $128010.1080 / 02786826.2019 .1676394,2020$. 
Baddock, M., Mockford, T., Bullard, J.E., and Thorsteinsson, Th.: Pathways of high-latitude dust in the North Atlantic. Earth and Planetary Science Letters, 459: 170 - 182. doi: 10.1016/j.epsl.2016.11.034, 2017.

Baklanov A., Rigina O. Environmental modeling of dusting from the mining and concentration sites in the Kola Peninsula, Northwest Russia. The XI World Clear Air and Environment Congress, 14-18 September 1998, Durban, South Africa, IUAPPA-NACA. Durban, v. 1, 4F-3, p. 1-18, 1998.

Baklanov, A., A. Mahura, L. Nazarenko, N. Tausnev, A Kuchin, O. Rigina: Atmospheric Pollution and Climate Change in

Baldo, C., Formenti, P., Nowak, S., Chevaillier, S., Cazaunau, M., Pangui, E., Di Biagio, C., Doussin, J.-F., Ignatyev, K., Dagsson-Waldhauserova, P., Arnalds, O., MacKenzie, A. R., and Shi, Z.: Distinct chemical and mineralogical composition of Icelandic dust compared to northern African and Asian dust, Atmos. Chem. Phys., 20, 13521-13539, https://doi.org/10.5194/acp-20-13521-2020, 2020.

Baratoux D, N. Mangold, O. Arnalds, J.-M. Bardintzeff, B. Platevoët, M. Grégoire and P. Pinet, 2011, Volcanic sands of Iceland - Diverse origins of aeolian sand deposits revealed at Dyngjusandur and Lambahraun. EARTH SURFACE PROCESSES AND LANDFORMS Earth Surf. Process. Landforms, DOI: 10.1002/esp.2201, 2011.

Beckett, F., Kylling, A., Sigurðardóttir, G., von Löwis, S., and Witham, C.: Quantifying the mass loading of particles in an ash cloud remobilized from tephra deposits on Iceland, Atmos. Chem. Phys., 17, 4401-4418, 2017.

Bertran P, Mathieu Bosq, Quentin Borderie, Céline Coussot, Sylvie Coutard, Laurent Deschodt, Odile Franc, Philippe Gardère, 1305 Morgane Liard, Patrice Wuscher: Revised map of European aeolian deposits derived from soil texture data, Quaternary Science Reviews, 10.1016/j.quascirev.2021.107085, 266, (107085), 2021.

Bhattachan, A., L. Wang, M. F. Miller, K. J. Licht, and P. D'Odorico: Antarctica's Dry Valleys: A potential source of soluble iron to the Southern Ocean?, Geophys. Res. Lett., 42, 1912-1918, doi:10.1002/2015GL063419, 2015.

Bishop, J. K. B., Davis, R. E., and Sherman, J. T.: Robotic observations of dust storm enhancement of carbon biomass in the North Pacific. Science. https://doi.org/10.1126/science.1074961, 2002. 
Bodas-Salcedo, A., K. D. Williams, M. A. Ringer, I. Beau, J. N. S. Cole, J. L. Dufresne, T. Koshiro, B. Stevens, Z. Wang, and 1315 T. Yokohata: Origins of the Solar Radiation Biases over the Southern Ocean in CFMIP2 Models, J. Clim., 27(1), 41-56, doi:10.1175/jcli-d-13-00169.1, 2014.

Bond, T. C., Doherty, S. J., Fahey, D. W., Forster, P. M., Berntsen, T., DeAngelo, B. J., et al.: Bounding the role of black carbon in the climate system: a scientific assessment. J. Geophys. Res. Atmos. 188, 5380-5552. doi: 10.1002/jgrd.50171, 2013.

Boy, M., Thomson, E. S., Acosta Navarro, J.-C., Arnalds, O., Batchvarova, E., Bäck, J., Berninger, F., Bilde, M., Brasseur, Z., Dagsson-Waldhauserova, P., Castarède, D., Dalirian, M., de Leeuw, G., Dragosics, M., Duplissy, E.-M., Duplissy, J., Ekman, A. M. L., Fang, K., Gallet, J.-C., Glasius, M., Gryning, S.-E., Grythe, H., Hansson, H.-C., Hansson, M., Isaksson, E., 1325 Iversen, T., Jonsdottir, I., Kasurinen, V., Kirkevåg, A., Korhola, A., Krejci, R., Kristjansson, J. E., Lappalainen, H. K., Lauri, A., Leppäranta, M., Lihavainen, H., Makkonen, R., Massling, A., Meinander, O., Nilsson, E. D., Olafsson, H., Pettersson, J. B. C., Prisle, N. L., Riipinen, I., Roldin, P., Ruppel, M., Salter, M., Sand, M., Seland, Ø., Seppä, H., Skov, H., Soares, J., Stohl, A., Ström, J., Svensson, J., Swietlicki, E., Tabakova, K., Thorsteinsson, T., Virkkula, A., Weyhenmeyer, G. A., Wu, Y., Zieger, P., and Kulmala, M.: Interactions between the atmosphere, cryosphere, and ecosystems at northern high latitudes, Atmos. 1330 Chem. Phys., 19, 2015-2061, https://doi.org/10.5194/acp-19-2015-2019, 2019.

Brabets,T P., (1997) Geomorphology of the lower Copper River, Alaska I by Timothy P. Brabets, U.S. Geological Survey professional paper ; 1581, https://pubs.usgs.gov/pp/1581/report.pdf

1335 Brédoire F, Bakker MR, Augusto L, Barsukov PA, Derrien D, Nikitich P, Rusalimova O, Zeller B, Acha DL (2015) What is the P value of Siberian soils? Biogeosci Discuss 12:19819-19859.

Bullard, J. E.: The distribution and biogeochemical importance of high-latitude dust in the Arctic and Southern OceanAntarctic regions, Journal of Geophysical Research-Atmospheres, 122, 3098-3103, doi: 10.1002/2016jd026363, 2016.

Bullard J. and Martin J. Austin. Dust generation on a proglacial floodplain, West Greenland Article in Aeolian Research · June 2011 DOI: 10.1016/j.aeolia.2011.01.002, 2011.

Bullard, J.E. and T. Mockford. Seasonal and decadal variability of dust observations in the Kangerlussuaq area, west 1345 Greenland, Arctic, Antarctic, and Alpine Research, 50:1, S100011, DOI: 10.1080/15230430.2017.1415854, 2018. 
Bullard, J. E., Baddock, M., Bradwell, T., Crusius, J., Darlington, E., Gaiero, D., ... McCulloch, R. (2016). High-latitude dust in the Earth system. Reviews of Geophysics, 54(2), 447-485, 2016.

1350 Butwin, MK, Melissa A. Pfeffer, Sibylle von Löwis, Eivind W. N. Støren, Eniko Bali, Throstur Thorsteinsson: Properties of dust source material and volcanic ash in Iceland, Sedimentology, Volume 67, Issue6, Pages 3067-3087, https://doi.org/10.1111/sed.12734, 2020.

Chewings, J., Atkins, C, Dunbar, G., and Golledge, N. Aeolian sediment transport and deposition in a modern high latitude glacial marine environment. Sedimentology, v. 61, (6), p. 1485-1882, doi: 10.1111/sed.12108, 2014.

Conca, E., Abollino, O., Giacomino, A., Buoso, S., Traversi, R., Becagli, S., Grotti, M., and Malandrino, M.: Source identification and temporal evolution of trace elements in PM10 collected near to Ny-Ålesund (Norwegian Arctic), Atmos. Environ., 203, 153-165, https://doi.org/10.1016/j.atmosenv.2019.02.001, 2019.

Coronato, A., Mazzoni, E., Vázquez, M., and Coronato, F. PATAGONIA Una síntesis de su Geografía Física (Ediciones). Río Gallegos, Argentina: Universidad Nacional de la Patagonia Austral. Retrieved from http://www.unpa.edu.ar/sites/default/files/publicaciones_adjuntos/PATAGONIA_una sintesis de su geografia fisica web_0.pdf, 2017.

Cosentino, N. J., Ruiz-Etcheverry, L. A., Bia, G. L., Simonella, L. E., Coppo, R., Torre, G., et al. Does Satellite Chlorophylla Respond to Southernmost Patagonian Dust? A Multi-year, Event-Based Approach. Journal of Geophysical Research: Biogeosciences, 125(12). https://doi.org/10.1029/2020JG006073, 2020.

Creamean J.M., Suski K.J., Rosenfeld D., Cazorla A., DeMott P.J., Sullivan R.C., White A.B., Ralph F.M., Minnis P., Comstock J.M., Tomlinson J.M., Prather K.A.: Dust and biological aerosols from the Sahara and Asia influence precipitation in the Western U.S., Science, 339 (6127), pp. 1572-1578. DOI: 10.1126/science.1227279, 2013.

Crespi-Abril, A. C., Soria, G., De Cian, A., and López-Moreno, C. (2017). Roaring forties: An analysis of a decadal series of data of dust in Northern Patagonia. Atmospheric Environment. https://doi.org/10.1016/j.atmosenv.2017.11.019,2017.

Crocchianti,S.; Moroni,B.; Waldhauserová, P.D.; Becagli, S.; Severi, M.; Traversi, R.; Cappelletti, D. Potential Source Contribution Function Analysis of High Latitude Dust Sources over the Arctic: Preliminary Results and Prospects. Atmosphere 2021, 12, 347. https://doi.org/10.3390/ atmos12030347, 2021. 
https://doi.org/10.5194/acp-2021-963

Preprint. Discussion started: 17 December 2021

(C) Author(s) 2021. CC BY 4.0 License.

(c) (i)
Atmospheric

Chemistry

and Physics

Discussions

Csavina et al. 2012, https://doi.org/10.1016/j.scitotenv.2012.06.013,2012.

Crusius, J.: Dissolved Fe Supply to the Central Gulf of Alaska Is Inferred to Be Derived From Alaskan Glacial Dust That Is Not Resolved by Dust Transport Models. Journal of Geophysical Research: Biogeosciences, 126(6), e2021JG006323. https://doi.org/https://doi.org/10.1029/2021JG006323, 2021.

Crusius, J., Schroth, A. W., Gasso, S., Moy, C. M., Levy, R. C., and Gatica, M.: Glacial flour dust storms in the Gulf of Alaska: Hydrologic and meteorological controls and their importance as a source of bioavailable iron, Geophysical Research Letters, 38, doi: 10.1029/2010g1046573, 2011.

Crusius, J., Schroth, A. W., Resing, J. A., Cullen, J., and Campbell, R. W. Seasonal and spatial variabilities in northern Gulf of Alaska surface water iron concentrations driven by shelf sediment resuspension, glacial meltwater, a Yakutat eddy, and dust. Global Biogeochemical Cycles, 31(6), 942-960. https://doi.org/10.1002/2016GB005493, 2017.

Cvetkovic et al., 2021: Fully dynamic numerical prediction model for dispersion of Icelandic mineral dust (submitted), 2021.

Dagsson-Waldhauserova P. and Meinander O. Editorial: Atmosphere - cryosphere interaction in the Arctic, at high latitudes and mountains with focus on transport, deposition and effects of dust, black carbon, and other aerosols.Front. Earth Sci., 18 December 2019, https://doi.org/10.3389/feart.2019.00337, 2019.

Dagsson-Waldhauserova, P. and Meinander, O., eds. Atmosphere - Cryosphere Interaction in the Arctic, at High Latitudes and Mountains With Focus on Transport, Deposition and Effects of Dust, Black Carbon, and Other Aerosols. Lausanne: Frontiers Media SA. ISSN 1664-8714, ISBN 978-2-88963-504-7, doi: 10.3389/978-2-88963-504-7, e-book, 2020.

1405 Dagsson-Waldhauserova, P., O. Arnalds, H. Ólafsson, L. Skrabalova, G. Sigurðardóttir, M. Branis, J. Hladil, R. Skala, T. Navratil, L. Chadimova, S. Löwis, T. Thorsteinsson, H. Carlsen, I. Jónsdóttir, Physical properties of suspended dust during moist and low wind conditions in Iceland. Icelandic Agricultural Sciences 27, 25-39, 2014.

Dagsson-Waldhauserova, P., O. Arnalds, H. Olafsson, J. Hladil, R. Skala, T. Navratil, L. Chadimova, O. Meinander: Snow1410 Dust Storm: Unique case study from Iceland, March 6-7, 2013. Aeolian Res 16, 69-74, 2015.

Dagsson-Waldhauserova P, Magnusdottir AÖ, Olafsson H, Arnalds O: The spatial variation of dust particulate matter concentrations during two Icelandic dust storms in 2015. Atmosphere, 7, 77, 2016. 
1415 Dagsson-Waldhauserova, P., Renard, J.-B., Olafsson, H., Vignelles, D., Berthet, G., Verdier, N., Duverger, V.: Vertical distribution of aerosols in dust storms during the Arctic winter. Scientific Reports 6, 1-11, 2019.

Dang, C., Warren, S. G., Fu, Q., Doherty, S. J., Sturm, M., and Su, J.: Measurements of light-absorbing particles in snow across the Arctic, North America, and China: Effects on surface albedo, J. Geophys. Res. Atmos., 122, 10,149- 10,168, doi:10.1002/2017JD027070, 2017.

Diaz, M.A., Welch, S.A., Sheets, J.M., Welch, K.A., Khan, A.L., Adams, B.J., McKnight, D.M., Cary, S.C, W.B, Lyons: Geochemistry of aeolian material from the McMurdo Dry Valleys, Antarctica: Insights into Southern Hemisphere dust sources. Earth and Planetary Science Letters 547 https://doi.org/10.1016/j.epsl.2020.116460, 2020.

Dijkmans, J. W. A., and T. E. Törnqvist: Modern periglacial eolian deposits and landforms in the Søndre Strømfjord area, West Greenland and their palaeoenvironmental implications. Meddelelser Om Grønland Geoscience, 25:3-39, 1991.

Doody JP, Ferreira M, Lombardo S, Lucius I, Misdorp R, Niesing H, Salman A, Smallegange M (eds): Living with coastal 1430 erosion in Europe - sediment and space for sustainability. Results from the EUROSION study, European Commission, Office for Official Publications of the European Communities. Available at: http://www.eurosion.org/project/eurosion_en.pdf (last accessed 19 November 2021), 2004.

Đorđević D., Tošić I., Sakan S., Petrović S., Đuričić-Milanković J., Finger D.C. and Dagsson-Waldhauserová P.: Can Volcanic 1435 Dust Suspended From Surface Soil and Deserts of Iceland Be Transferred to Central Balkan Similarly to African Dust (Sahara)? Frontiers in Earth Sciences 7, 142-154, 2019.

Dragosics, M., Meinander, O., Jonsdottir, T. et al. Insulation effects of Icelandic dust and volcanic ash on snow and ice, Arabian Journal of Geosciences Volume: 9 Issue: 2, Dust special issue, DOI: 10.1007/s12517-015-2224-6, 2016.

Dörnbrack, A., Stachlewska, I. S., Ritter, C., and Neuber, R.: Aerosol distribution around Svalbard during intense easterly winds, Atmos. Chem. Phys., 10, 1473-1490, https://doi.org/10.5194/acp-10-1473-2010, 2010.

Evangeliou, N., Shevchenko, V. P., Yttri, K. E., Eckhardt, S., Sollum, E., Pokrovsky, O. S., Kobelev, V. O., Korobov, V. B., 1445 Lobanov, A. A., Starodymova, D. P., Vorobiev, S. N., Thompson, R. L., and Stohl, A.: Origin of elemental carbon in snow from western Siberia and northwestern European Russia during winter-spring 2014, 2015 and 2016, Atmos. Chem. Phys., 18, 963-977, https://doi.org/10.5194/acp-18-963-2018, 2018. 
https://doi.org/10.5194/acp-2021-963

Preprint. Discussion started: 17 December 2021

(C) Author(s) 2021. CC BY 4.0 License.

(c) (i)
Atmospheric

Chemistry

and Physics

Discussions

Finlayson-Pitts, B.J., James N. Pitts, Jr., Chemistry of the upper and lower atmosphere: theory, experiments, and applications,

1450

Elsevier, 1999, pp 969.

Flanner, M. G., Zender, C. S., Randerson, J. T., and Rasch, P. T.: Present day climate forcing and response from black carbon in snow. J. Geophys. Res. 112:D11202. doi: 10.1029/2006JD008003, 2007.

1455 Foroutan, H., et al. Development and evaluation of a physics-based windblown dust emission scheme implemented in the CMAQ modeling system, J Adv Model Earth Syst. 2017 Mar; 9(1): 585-608, 2017.

Forsström, S., Isaksson, E., Skeie, R. B., Ström, J., Pedersen, C. A., Hudson, S. R., Berntsen, T. K., Lihavainen, H., Godtliebsen, F. and Gerland, S.: Elemental carbon measurements in European Arctic snow packs, J. Geophys. Res. Atmos., $1460118,13,614-13,627,2013$.

Fountain, A.G., Levy, J.S., Gooseff, M.N., Van Horn, D: The McMurdo Dry Valleys: A landscape on the threshold of change (2014). Geomorphology 225, 15, P, 25-35, doi:/10.1016/j.geomorph.2014.03.044, 2014.

1465 Frey, W. R., and J. E. Kay (2018), The influence of extratropical cloud phase and amount feedbacks on climate sensitivity, Climate Dynamics, 50(7), 3097-3116, doi:10.1007/s00382-017-3796-5.

Gaiero, D. M., Probst, J.-L., Depetris, P. J., Bidart, S. M., and Leleyter, L.: Iron and other transition metals in Patagonian riverborne and windborne materials: geochemical control and transport to the southern South Atlantic Ocean. Geochimica et 1470 Cosmochimica Acta, 67(19), 3603-3623. https://doi.org/https://doi.org/10.1016/S0016-7037(03)00211-4, 2003.

Gaitán, J. J., López, C. R., and Bran, D.: Efectos del pastoreo sobre el suelo y la vegetación en la estepa patagónica. Ci. Suelo (Argentina), 27(2), 261-270, 2009.

1475 Gallet, J.-C., Björkman, M. P., Larose, C., Luks, B., Martma, T., and Zdanowicz, C.: Protocols and recommendations for the measurement of snow physical properties, and sampling of snow for black carbon, water isotopes, major ions and microorganisms, Norsk Polarinstitutt, 27 pp., 2018.

Gao, Y., Marsay, C. M., Yu, S., Fan, S. Y., Mukherjee, P., Buck, C. S., and Landing, W. M.: Particle-Size Variability of 1480 Aerosol Iron and Impact on Iron Solubility and Dry Deposition Fluxes to the Arctic Ocean, Scientific Reports, 9, doi: 10.1038/s41598-019-52468-z, 2019. 
Gardner, A. S., and Sharp, M. J.: A review of snow and ice albedo and the development of a new physically based broadband albedo parameterization. J. Geophys. Res. 115:F01009. doi: 10.1029/2009JF001444, 2010.

Gassó, S., twitter.com/SanGasso, 2 Gassó, Santiago (@SanGasso). "Sunrise in Alaska and more \#highlatitudedust is visible in Larsen Bay, just downwind from the Ten Thousand Smokes Valley in @ KatmaiNPS, visible in webcams and early GOES17 image." Nov 2, 2020 , Tweet, https://twitter.com/SanGasso/status/1323716227793997824?, 2020a.

1490 Gassó, Santiago (@SanGasso)."More \#highlatitudedust today in \#Alaska , 3 active sources identified in \#NOAA20. Surface webcams confirm dust presence." Nov 2, 2020 , Twitter. https://twitter.com/SanGasso/status/1323384615344640000, 2020b.

Gassó, Santiago (@SanGasso). "\#highlatitudedust in SE Alaska yesterday several plumes are visible in the spots where there is little snow " Jan, 27, 2021. Twitter. https://twitter.com/SanGasso/status/1354548215186644993021, $2021 \mathrm{a}$.

Gassó, S., twitter.com/SanGasso, 2 Gassó, Santiago (@SanGasso), "A very nice example of \#highlatitudedust activity in western \#Greenland“, Oct 19, 2021, https://twitter.com/SanGasso/status/1450468551379329029, 2021b.

Gassó, S., and Stein, A. F.: Does dust from Patagonia reach the sub-Antarctic Atlantic Ocean? Geophysical Research Letters, 1500 34(1), L01801. https://doi.org/10.1029/2006GL027693, 2007.

Gassó, S., and Torres, O.: Temporal Characterization of Dust Activity in the Central Patagonia Desert (Years 1964-2017). Journal of Geophysical Research: Atmospheres, 124(6), 3417-3434. https://doi.org/10.1029/2018JD030209, 2019.

1505 Gassó, S., Stein, A., Marino, F., Castellano, E., Udisti, R., and Ceratto, J. A combined observational and modeling approach to study modern dust transport from the Patagonia desert to East Antarctica. Atmospheric Chemistry and Physics, 10(17), 8287-8303. https://doi.org/10.5194/acp-10-8287-2010, 2010.

George, C, Ammann, M, D’Anna, B, Donaldson, D J, Nizkorodov, S A.: Heterogeneous Photochemistry in the Atmosphere. 1510 Chem. Rev. 115, 4218-4258] [Tang, M, Cziczo, D J, Grassian, V H, 2016. Interactions of sater with mineral dust aerosol: Water adsorption, hygroscopicity, cloud condensation, and ice nucleation. Chem. Rev. 116, 4205-4259, 2015.

Gili, S., Vanderstraeten, A., Chaput, A., King, J., Gaiero, D., Delmonte, B., Vallelonga, P., Formenti, P., Di Biagio, C., Cazanau, M. and Pangui, E.: Southern Africa: The Missing Piece To The Dust Provenance Puzzle of East Antarctica? 1515 Communications Earth \& Environment, 2021. 
https://doi.org/10.5194/acp-2021-963

Preprint. Discussion started: 17 December 2021

(C) Author(s) 2021. CC BY 4.0 License.

(c) (P)
Atmospheric

Chemistry

and Physics

Discussions

Gillies, J. A., W. G. Nickling, and M. Tilson: Frequency, magnitude and characteristics of aeolian sediment transport: McMurdo Dry Valleys, Antarctica, J. Geophys. Res. Earth Surf., 118, 461-479, doi:10.1002/jgrf.20007.2013.

Groot Zwaaftink, C. D., Grythe, H., Skov, H., and Stohl, A.: Substantial contribution of northern high-latitude sources to mineral dust in the Arctic, Journal of Geophysical Research-Atmospheres, 121, 13678-13697, doi: 10.1002/2016jd025482, 2016.

1525 Groot Zwaaftink, C. D., Arnalds, O., Dagsson-Waldhauserova, P., Eckhardt, S., Prospero, J. M., and Stohl, A.: Temporal and spatial variability of Icelandic dust emission and atmospheric transport, Atmos. Chem. Phys., 17, $10865-10878,2017$.

Gunnarsson, A., Gardarsson, S. M., Pálsson, F., Jóhannesson, T., and Sveinsson, Ó. G. B.: Annual and interannual variability and trends of albedo for Icelandic glaciers. The Cryosphere 15, 547-570, 2020.

Hadley, D., G. L. Hufford, and J. J. Simpson, Resuspension of relic volcanic ash and dust from Katmai: Still an aviation hazard, Weather Forecast., 19(5), 829-840, https://doi.org/10.1175/1520-0434(2004)019<0829:RORVAA>2.0.CO;2, 2004.

Hadley, O., and Kirchstetter, T.: Black-Carbon reduction of snow albedo. Nat. Clim. Change 2, 437-440. doi:

10.1038/nclimate1433, 2012.

Hardy M., and Cornu S. Location of natural trace elements in silty soils using particle-size fractionation. Geoderma, 133, 295308. https://doi.org/10.1016/j.geoderma.2005.07.015, 2006.

1540 Harrison, A. D., K. Lever, A. Sanchez-Marroquin, M. A. Holden, T. F. Whale, M. D. Tarn, J. B. McQuaid, and B. J. Murray: The ice-nucleating ability of quartz immersed in water and its atmospheric importance compared to K-feldspar, Atmos. Chem. Phys., 19(17), 11343-11361, doi:10.5194/acp-19-11343-2019, 2019.

Hedding DW, Werner Nel, Ryan L. Anderson, Aeolian processes and landforms in the sub-Antarctic: preliminary observations 1545 from Marion Island, Polar Research, 10.3402/polar.v34.26365, 34, 1, (26365), 2015.

Heindel RC, Lauren E Culler, Ross A Virginia, Rates and processes of aeolian soil erosion in West Greenland, The Holocene, 10.1177/0959683616687381, 27, 9, (1281-1290), 2017. 
1550 Hernández, M. A., González, N., and Hernández, L.: Late Cenozoic Geohydrology of Extra-Andean Patagonia, Argentina. In J. Rabassa (Ed.), The Late Cenozoic of Patagonia and Tierra del Fuego (Vol. 11, pp. 497-509). Elsevier. https://doi.org/https://doi.org/10.1016/S1571-0866(07)10024-5, 2008

Hobbs, W. H. 1942. Wind: The dominant transportation agent within extramarginal zones to continental glaciers. The Journal of Geology 50 (5):556-59. doi:10.1086/625072

Hojan, M., Rurek, M., Więcław, M., and Krupa, A.: Effects of Extreme Dust Storm in Agricultural Areas (Poland, the Greater Lowland). Geosciences, 9, 106, doi:10.3390/geosciences9030106, 2019.

1560 IPCC, 2013: Climate Change 2013: The Physical Science Basis. Contribution of Working Group I to the Fifth Assessment Report of the Intergovernmental Panel on Climate Change [Stocker, T.F., D. Qin, G.-K. Plattner, M. Tignor, S.K. Allen, J. Boschung, A. Nauels, Y. Xia, V. Bex and P.M. Midgley (eds.)]. Cambridge University Press, Cambridge, United Kingdom and New York, NY, USA, 1535 pp, 2013.

1565 IPCC, 2019: IPCC Special Report on the Ocean and Cryosphere in a Changing Climate [H.-O. Pörtner, D.C. Roberts, V. Masson-Delmotte, P. Zhai, M. Tignor, E. Poloczanska, K. Mintenbeck, A. Alegría, M. Nicolai, A. Okem, J. Petzold, B. Rama, N.M. Weyer (eds.)]. In press. (last accessed 19 November 2021), 2019.

IPCC, 2021: Climate Change 2021: The Physical Science Basis. Contribution of Working Group I to the Sixth

1570 Assessment Report of the Intergovernmental Panel on Climate Change [Masson-Delmotte, V., P. Zhai, A. Pirani, S.L. Connors, C. Péan, S. Berger, N. Caud, Y. Chen, L. Goldfarb, M.I. Gomis, M. Huang, K. Leitzell, E. Lonnoy, J.B.R. Matthews, T.K. Maycock, T. Waterfield, O. Yelekçi, R. Yu, and B. Zhou (eds.)]. Cambridge University Press. In Press, (last accessed 19 November 2021), 2021.

1575 Irish, V. E., et al.: Ice nucleating particles in the marine boundary layer in the Canadian Arctic during summer 2014, Atmos. Chem. Phys., 19(2), 1027-1039, doi:10.5194/acp-19-1027-2019, 2019.

Ito, A., and Kok, J. F.: Do dust emissions from sparsely vegetated regions dominate atmospheric iron supply to the Southern Ocean?, Journal of Geophysical Research-Atmospheres, 122, 3987-4002, doi: 10.1002/2016jd025939, 2017.

Jacobi, H.-W., Obleitner, F., Da Costa, S., Ginot, P., Eleftheriadis, K., Aas, W., and Zanatta, M.: Deposition of ionic species and black carbon to the Arctic snowpack: combining snow pit observations with modeling, Atmos. Chem. Phys., 19, 1036110377, https://doi.org/10.5194/acp-19-10361-2019, 2019. 
1585 Johnson, M. S., Meskhidze, N., Kiliyanpilakkil, V. P., and Gassó, S.: Understanding the transport of Patagonian dust and its influence on marine biological activity in the South Atlantic Ocean. Atmospheric Chemistry and Physics, 11(6), 2487-2502, 2011.

Kanakidou, M., Myriokefalitakis, S., and Tsigaridis, K.: Aerosols in atmospheric chemistry and biogeochemical cycles of nutrients, Environmental Research Letters, 13, doi: 10.1088/1748-9326/aabcdb, 2018.

Kandler, K.; Schneiders, K.; Heuser, J.; Waza, A.; Aryasree, S.; Althausen, D.; Hofer, J.; Abdullaev, S.F.; Makhmudov, A.N. Differences and Similarities of Central Asian, African, and Arctic Dust Composition from a Single Particle Perspective. Atmosphere 2020, 11, 269. https://doi.org/10.3390/atmos11030269, 2020.

Kasimov, N. S., Vlasov, D. V., and Kosheleva, N. E.: Enrichment of road dust particles and adjacent environments with metals and metalloids in eastern Moscow, Urban Clim., 32, 100638, https://doi.org/10.1016/j.uclim.2020.100638, 2020.

Kavan J, Ondruch J, Nývlt D, Hrbáček F, Carrivick JL, Láska K.: Seasonal hydrological and suspended sediment transport 1600 dynamics in proglacial streams, James Ross Island, Antarctica. Geografiska Annaler: Series A, Physical Geography 99: 3855. DOI: 10.1080/04353676.2016.1257914, 2017.

Kavan J, Dagsson-Waldhauserova P, Renard JB, Láska K, Ambrožová, K.: Aerosol concentrations in relationship to local atmospheric conditions on James Ross Island, Antarctica. Frontiers in Earth Science 6: DOI: 10.3389/feart.2018.00207, 2018.

Kavan Jan, Kamil Láska K, Adam Nawrot A, and Tomasz Wawrzyniak T. 2020a. High Latitude Dust Transport Altitude Pattern Revealed from Deposition on Snow, Svalbard. Atmosphere 2020, 11, 1318; doi:10.3390/atmos11121318., 2020 a.

Kavan J, Nývlt D, Láska K, Engel Z, Kňažková M. 2020b. High latitude dust deposition in snow on glaciers of James Ross

Island, Antarctica. Earth Surface Processes and Landforms. DOI: 10.1002/esp.4831, 2020b.

Khan, A. L., Dierssen, H., Schwarz, J. P., Schmitt, C., Chlus, A., Hermanson, M., Painter, T. H., and McKnight, D. M.: Impacts of coal dust from an active mine on the spectral reflectance of Arctic surface snow in Svalbard, Norway, J. Geophys. Res., 122, 1767-1778, https://doi.org/10.1002/2016jd025757, 2017. 
Kňažková, M., Hrbáček, F., Kavan, J., Nývlt, D. Effect of hyaloclastite breccia boulders on meso-scale periglacial-aeolian landsystem in semi-arid Antarctic environment, James Ross Island, Antarctic Peninsula. Cuadernos de Investigación Geográfica. DOI: 10.18172/cig.3800, 2020.

1620 Kok JF, et al.: An improved dust emission model—Part 1: Model description and comparison against measurements, Atmos. Chem. Phys, 14(23), 13,023-13,041, 2014.

Koroleva, T. V., Krechetov, P. P., Semenkov, I. N., Sharapova, A. V. and Kondrat'ev, A. D.: Transformation of chemical composition of snow in the impact areas of the first stage of the expandable launch system Proton in Central Kazakhstan, Russ.

1625 Meteorol. Hydrol., 41(8), 585-591, doi:10.3103/S1068373916080094, 2016.

Koroleva, T. V., Sharapova, A. V. and Krechetov, P. P.: A chemical composition of snow on areas exposed to space-rocket activities pollution (Altai republic), Gig. i Sanit., doi:10.1882/0016-9900-2017-96-5-432-437, 2017.

1630 Kuhlman, H.: Den potentielle jordfygning på danske marker. Teoretiske beregninger vedrørende jordmaterialets vindbevægelighed. Geografisk Tidsskrift - Danish Journal of Geography, 59. Retrieved from https://tidsskrift.dk/geografisktidsskrift/article/view/46533, 1960.

Kuhns, Hampden \& Gillies, John \& Etyemezian, Vicken \& Nikolich, George \& King, James \& Zhu, Dongzi \& Uppapalli, 1635 Sebastian \& Engelbrecht, Johann \& Kohl, Steve: Effect of Soil Type and Momentum on Unpaved Road Particulate Matter Emissions from Wheeled and Tracked Vehicles. Aerosol Science and Technology - AEROSOL SCI TECH. 44. 187-196. 10.1080/02786820903516844, 2010.

Kupiainen K.: Road dust from pavement wear and traction sanding. Monographs of the Boreal Environment Research, 1640 No. 26, 2007. Mono_26.indd (helsinki.fi).

Kupiainen, K., Ritola, R., Stojiljkovic, A., Pirjola, L., Malinen, A., and Niemi, J. Contribution of mineral dust sources to street side ambient and suspension PM10 samples. Atmospheric Environment, 147, 178-189. https://doi.org/10.1016/j.atmosenv.2016.09.059, 2016.

Kylling A., Groot Zwaaftink, C. D., and Stohl, A.: Mineral dust instantaneous radiative forcing in the Arctic. Geophysical Research Letters, 45, 4290-4298.https://doi.org/10.1029/2018GL077346, 2018. 
Lancaster, N., Nickling, W.G. and Gillies, J.A.: Sand transport by wind on complex surfaces: field studies in the McMurdo

Lappalainen, H., Petäjä, T., Vihma, T., Räisänen, J., Baklanov, A., Chalov, S., Esau, I., Ezhova, E., Leppäranta, M., Pozdnyakov, D., Pumpanen, J., Andreae, M. O., Arshinov, M., Asmi, E., Bai, J., Bashmachnikov, I., Belan, B., Bianchi, F., Biskaborn, B., Boy, M., Bäck, J., Cheng, B., Chubarova, N. Y., Duplissy, J., Dyukarev, E., Eleftheriadis, K., Forsius, M., Heimann, M., Juhola, S., Konovalov, V., Konovalov, I., Konstantinov, P., Koster, K., Lapsina, E., Lintunen, A., Mahura, A., Makkonen, R., Malkhazova, S., Mammarella, I., Mammola, S., Mazon, S., Meinander, O., Mikhailov, E., Miles, V., Myslenko, S., Orlov, D., Paris, J.-D., Pirazzini, R., Popovicheva, O., Pulliainen, J., Rautiainen, K., Sachs, T., Shevchenko, V., Skorokhod, A., Stohl, A., Suhonen, E., Thomson, E. S., Tsidilina, M., Tynkkynen, V.-P., Uotila, P., Virkkula, A., Voropay, N., Wolf, T., Yasunaka, S., Zhang, J., Qui, Y., Ding, A., Guo, H., Bondur, V., Kasimov, N., Zilitinkevich, S., Kerminen, V.-M., and 1660 Kulmala, M.: Overview: Recent advances on the understanding of the Northern Eurasian environments and of the urban air quality in China - Pan Eurasian Experiment (PEEX) program perspective, Atmos. Chem. Phys. Discuss., https://doi.org/10.5194/acp-2021-341, accepted, 2021.

LeBlanc S.E., Redemann J., Flynn C., Pistone K., Kacenelenbogen M., Segal-Rosenheimer M., Shinozuka Y., Dunagan S., 1665 Dahlgren R.P., Meyer K., Podolske J., Howell S.G., Freitag S., Small-Griswold J., Holben B., Diamond M., Wood R., Formenti P., Piketh S., Maggs-Koelling G., Gerber M., and Namwoond A.: Above-cloud aerosol optical depth from airborne observations in the southeast Atlantic (2020) Atmospheric Chemistry and Physics, 20 (3), pp. 1565-1590 DOI: 10.5194/acp20-1565-2020, 2020.

1670 Lewandowski, M.; Kusiak, M.A.; Werner, T.; Nawrot, A.; Barzycka, B.; Laska, M.; Luks, B. Seeking the Sources of Dust: Geochemical and Magnetic Studies on "Cryodust" in Glacial Cores from Southern Spitsbergen (Svalbard, Norway). Atmosphere 2020, 11, 1325. https://doi.org/10.3390/atmos11121325. 2020.

Llanos, M. E., Behr, S. J., Gonzalez, J. H., Colombani, E. N., Buono, G. G., and Escobar, J. M.: Informe de las Variaciones 1675 del Lago Colhue Huapi mediante sensores remotos y su relación con las precipitaciones. Retrieved January 5, 2018, from https://inta.gob.ar/documentos/informe-de-las-variaciones-del-lago-colhue-huapi-mediante-sensores-remotos-y-su-relacioncon-las-precipitaciones, 2016.

Mahowald, N. M., Kloster, S., Engelstaedter, S., Moore, J. K., Mukhopadhyay, S., McConnell, J. R., Albani, S., Doney, S. C., 1680 Bhattacharya, A., Curran, M. A. J., Flanner, M. G., Hoffman, F. M., Lawrence, D. M., Lindsay, K., Mayewski, P. A., Neff, J., Rothenberg, D., Thomas, E., Thornton, P. E., and Zender, C. S.: Observed 20th century desert dust variability: impact on climate and biogeochemistry, Atmospheric Chemistry and Physics, 10, 10875-10893, doi: 10.5194/acp-10-10875-2010, 2010. 
Manninen, T., Anttila, K., Jääskeläinen, E., Riihelä, A., Peltoniemi, J., Räisänen, P., Lahtinen, P., Siljamo, N., Thölix, L., 1685 Meinander, O., Kontu, A., Suokanerva, H., Pirazzini, R., Suomalainen, J., Hakala, T., Kaasalainen, S., Kaartinen, H., Kukko, A., Hautecoeur, O., and Roujean, J.-L.: Effect of small-scale snow surface roughness on snow albedo and reflectance, The Cryosphere, 15, 793-820, https://doi.org/10.5194/tc-15-793-2021, 2021.

Markuse, Pierre: High latitude dust storm (silt), Nuussuaq Peninsula, Greenland - October 1st, 2020, 1690 https://www.flickr.com/photos/pierre markuse/50447335522/, contains modified Copernicus Sentinel data [2020], processed by Pierre Markuse, originally posted to Flickr by Pierre Markuse at https://flickr.com/photos/24998770@ N07/50447335522., reviewed on 25 October 2020 by FlickreviewR 2, licensed under the terms of the cc-by-2.0.2020, 2020.

Martin, J. H., and Fitzwater, S. E.: Iron deficiency limits phytoplankton growth in the north-east Pacific subarctic, Nature, 331, $1695341-343,1988$.

Martínez-García, A., Sigman, D. M., Ren, H., Anderson, R. F., Straub, M., Hodell, D. A., Jaccard, S. L., Eglinton, T. I., and Haug, G. H.: Iron fertilization of the Subantarctic Ocean during the last ice age, Science, 343, 1347-1350, 2014.

1700 Mazzonia, E., and Vazquez, M.: Desertification in Patagonia. In E. M. Latrubesse (Ed.), Natural Hazards and HumanExacerbated Disasters in Latin America (Vol. 13, pp. 351-377). Elsevier. https://doi.org/https://doi.org/10.1016/S0928$2025(08) 10017-7,2009$.

McCutcheon, J., Lutz, S., Williamson, C. et al.: Mineral phosphorus drives glacier algal blooms on the Greenland Ice Sheet. 1705 Nat Commun 12, 570, https://doi.org/10.1038/s41467-020-20627-w, 2021.

Meinander, O., Kazadzis, S., Arola, A., Riihelä, A., Räisänen, P., Kivi, R., Kontu, A., Kouznetsov, R., Sofiev, M., Svensson, J., Suokanerva, H., Aaltonen, V., Manninen, T., Roujean, J.-L., and Hautecoeur, O.: Spectral albedo of seasonal snow during intensive melt period at Sodankylä, beyond the Arctic Circle, Atmos. Chem. Phys., 13, 3793-3810, https://doi.org/10.5194/acp-13-3793-2013, 2013.

Meinander, O.; Kontu, A.; Virkkula, A.; et al., Brief communication: Light-absorbing impurities can reduce the density of melting snow, Cryosphere, Volume: 8 Issue: 3 Pages: 991-995, DOI: 10.5194/tc-8-991-2014, 2014.

1715 Meinander, O.; Dagsson-Waldhauserova, P.; Arnalds, O.: Icelandic volcanic dust can have a significant influence on the cryosphere in Greenland and elsewhere, Polar Research Volume: 35, DOI: 10.3402/polar.v35.31313, 2016. 
Meinander O., Backman, L., Saranko,O., Asmi, E., Rodriguez, E. and Sanchez, R.: Effects of high latitude dust on snow UV albedo and solar UV irradiance measured at Marambio during 2013-2017 with comparison to simulated UV irradiances, Geophysical Research Abstracts Vol. 20, EGU2018-2007, 2018 EGU General Assembly 2018, available at https://meetingorganizer.copernicus.org/EGU2018/EGU2018-2007.pdf, 2018.

Meinander, O., S. Chalov, H. Lappalainen, J. Ekman, K. Eleftheriadis, D. Frolov, A. Hyvärinen, V. Ivanov, N. Karvosenoja, K. Kupiainen, O. Popovicheva, I. Semenkov, L. Sogacheva, and The MSU Workshop Participants. About Black Carbon in the

1725 Arctic and Significance Compared to Hight-Latitude Dust Sources (Finnish-Russian Workshop at the Lomonosov Moscow State University, 17-18 September 2019, in Co-operation with MSU, INAR, PEEX, MFA/IBA and FMI), In: Proceedings of The Center of Excellence in Atmospheric Science (CoE ATM) Annual Seminar 2019, Editors: Tiia Laurila, Anna Lintunen, Markku Kulmala, Report series in aerosol science, available at: http://www.faar.fi/wpcontent/uploads/2019/11/CoE_proceedings_2019-compressed.pdf, p. 457-465, 2019a.

Meinander Outi, Dagsson-Waldhauserova P., Björnsson H., Petersen G.N., Moore K., Larsen J.N., Heininen L. 2019. Report of the IASC Workshop on Effects and Extremes of High Latitude Dust, 13-14 FEB 2019, in co-operation with the IceDust Aerosol Association, IBA-FIN-BCDUST-project of MFA of Finland, and EU COST InDust Action. Available at https://iasc.info/news/iasc-news/472-workshop-report-iasc-workshop-on-effects-and-extremes-of-high-latitude-dust, last 1735 accessed 3 June 2021, 2019b.

Meinander, O.; Heikkinen, E.; Aurela, M.; Hyvärinen, A.: Sampling, Filtering, and Analysis Protocols to Detect Black Carbon, Organic Carbon, and Total Carbon in Seasonal Surface Snow in an Urban Background and Arctic Finland $\left(>60^{\circ} \mathrm{N}\right)$. Atmosphere, 11, 923, https://doi.org/10.3390/atmos11090923, 2020a.

Meinander O., Kontu A., Kouznetsov R., Sofiev M.: Snow Samples Combined With Long-Range Transport Modeling to Reveal the Origin and Temporal Variability of Black Carbon in Seasonal Snow in Sodankylä $\left(67^{\circ} \mathrm{N}\right)$. Front. Earth Sci. 12 June 2020, https://doi.org/10.3389/feart.2020.00153, 2020 b.

1745 Meinander, O., Piedehierro, A., Welti, A., Kouznetsov, R., Heinonen, A., Viisanen, Y. and Laaksonen, A.: Saharan dust transported and deposited in Finland on February 23rd, 2021. EAC 2021 August 30-Septembre 3 2021, Abstract AAS 19-2 Paper ID 399, abstract available at: https://www.conftool.com/eac2021/index.php?page=browseSessions\&form_session=206\#paperID399; talk available at: https://www.youtube.com/watch?v=ssJ6k8sT0so. Book of abstracts for the 2021 European Aerosol Conference, A live virtual event, hosted by The Aerosol Society, https://eac2021.co.uk/book-of-abstracts, 2021, 2021. 
Meteosat 2019: Two dust clouds, one from northern Africa and one from Central Europe, travelled north towards Iceland and Greenland in late April 2019. Dust over Europe 22 April 2019 12:00 UTC, 23 April 06:00-12:30 UTC, 24 April 06:00 UTC, by Jochen Kerkmann and Vesa Nietosvaara (EUMETSAT), Ivan Smiljanicv (SCISYS), Izabela Zablocka (IMGW ), Mike 1755 Fromm (US Naval Research Laboratory, Published on 22 April 2019, available at: https://www.eumetsat.int/dust-over-europe, 2019.

Miller, M.E., Bowker, M.A., Reynolds, R.L. and Goldstein, H.L. (2012) Post-fire land treatments and wind erosion - lessons from the Milford Flat Fire, UT, USA. Aeolian Research, 7, 29- 44

Mockford, T., Bullard, J., Thorsteinsson, Th.: The dynamic effects of sediment availability on the relationship between wind speed and dust concentration. Earth Surface Processes and Landforms 43 (11), 2484-2492, 2018.

Montes, A., Rodríguez, S. S., and Domínguez, C. E. (2017). Geomorphology context and characterization of dunefields developed by the southern westerlies at drying Colhué Huapi shallow lake, Patagonia Argentina. Aeolian Research, 28(Supplement C), 58-70. https://doi.org/https://doi.org/10.1016/j.aeolia.2017.08.001

Montes, A., Rodríguez, S. S., and Domínguez, C. E.: Geomorphology context and characterization of dunefields developed by the southern westerlies at drying Colhué Huapi shallow lake, Patagonia Argentina. Aeolian Research, 28(Supplement C), 5870. https://doi.org/https://doi.org/10.1016/j.aeolia.2017.08.001,2017.

Moore, C. M., Mills, M. M., Milne, A., Langlois, R., Achterberg, E. P., Lochte, K., Geider, R. J., and La Roche, J.: Iron limits primary productivity during spring bloom development in the central North Atlantic, Global Change Biology, 12, 626-634, doi: 10.1111/j.1365-2486.2006.01122.x, 2006.

Mori, Tatsuhiro, Goto-Azuma, Kumiko, Kondo, Yutaka, Ogawa-Tsukagawa, Yoshimi, Miura, Kazuhiko, Hirabayashi, Motohiro, Oshima, Naga, Koike, M., Kupiainen, Kaarle, Moteki, Nobuhiro, Ohata, Sho, Sinha, P.R., Sugiura, Konosuke, Aoki, Teruo, Schneebeli, Martin, Steffen, Konrad, Sato, Atsushi, Tsushima, A., Makarov, V., Nagatsuka, N.: Black Carbon and

Moroni B., Becagli S., Bolzacchini E., Busetto M., Cappelletti D., Crocchianti S., Ferrero L., Frosini D., Lanconelli C., Lupi A., Maturilli M., Mazzola M., Perrone G., Sangiorgi G., Traversi R., Udisti R., Viola A. and Vitale V.: Vertical profiles and 
https://doi.org/10.5194/acp-2021-963

Preprint. Discussion started: 17 December 2021

(C) Author(s) 2021. CC BY 4.0 License.

(c) (i)
Atmospheric

Chemistry

and Physics

Discussions

chemical properties of aerosol particles upon Ny-Ålesund (Svalbard Islands). Advances in Meteorology, http://dx.doi.org/10.1155/2015/292081.2015, 2015.

Moroni B., Cappelletti D., Ferrero L., Crocchianti S., Busetto M., Mazzola M., Becagli S., Traversi R. and Udisti R.: Local vs. long-range sources of aerosol particles upon Ny-Ålesund (Svalbard Islands): mineral chemistry and geochemical records. Rendiconti Lincei. Scienze Fisiche e Naturali. DOI: 10.1007/s12210-016-0533-7, 2016

Moroni B, Arnalds O, Dagsson-Waldhauserová P, Crocchianti S, Vivani R and Cappelletti D (2018) Mineralogical and Chemical Records of Icelandic Dust Sources Upon Ny-Ålesund (Svalbard Islands). Front. Earth Sci. 6:187. doi: 10.3389/feart.2018.00187, 2018.

Murray, B. J., D. O'Sullivan, J. D. Atkinson, and M. E. Webb: Ice nucleation by particles immersed in supercooled cloud droplets, Chem. Soc. Rev., 41(19), 6519-6554, doi:10.1039/c2cs35200a, 2012.

Murray, K.T., Miller, M.F. and Bowser, S.S.: Depositional processes beneath coastal multi-year sea ice. Sedimentology, 60, $391-410,2013$.

1800

Murray, B. J., K. S. Carslaw, and P. R. Field: Opinion: Cloud-phase climate feedback and the importance of ice-nucleating particles, Atmos. Chem. Phys., 21(2), 665-679, doi:10.5194/acp-21-665-2021, 2021.

Möller, R., Möller, M., Kukla, P. A., and Schneider, C.: Impact of supraglacial deposits of tephra from Grimsvötn volcano, 1805 Iceland, on glacier ablation. J. Glaciol. 62, 933-943. doi: 10.1017/jog.2016.82, 2016.

Nagatsuka, Naoko, Goto-Azuma, Kumiko, Tsushima, Akane, Fujita, Koji , Matoba, Sumito, Onuma, Yukihiko, Dallmayr, Remi, Kadota, Moe , Hirabayashi, Motohiro, Ogata, Jun, Ogawa-Tsukagawa, Yoshimi, Kitamura, Kyotaro, Minowa, Masahiro, Komuro, Yuki , Motoyama, Hideaki , Aoki, Teruo.: Variations in mineralogy of dust in an ice core obtained from northwestern Greenland over the past 100 years. Climate of the Past. 17. 1341-1362. 10.5194/cp-17-1341-2021, 2021.

Nickling, W. Eolian sediment transport during dust storms: Slims River valley, Yukon Territory. Canadian Journal of Earth Science 15:1069-1084, 1978.

1815 Nickling, W. G., and Brazel, A. J. Surface wind characteristics along the icefield ranges, Yukon Territory, Canada. Arctic and Alpine Research 17, 125-134. doi:10.2307/1550842, 1985. 
Nickovic, S., Cvetkovic, B., Madonna, F., Rosoldi, M., Pejanovic, G., Petkovic, S., and Nikolic, J.: Cloud ice caused by atmospheric mineral dust - Part 1: Parameterization of ice nuclei concentration in the NMME-DREAM model, Atmos. Chem. Phys., 16, 11367-11378, https://doi.org/10.5194/acp-16-11367-2016, 2016.

Nielsdottir, M. C., Moore, C. M., Sanders, R., Hinz, D. J., and Achterberg, E. P.: Iron limitation of the postbloom phytoplankton communities in the Iceland Basin, Global Biogeochemical Cycles, 23, doi: 10.1029/2008gb003410, 2009.

Nordic Council of Ministers. Road dust and PM10 in the Nordic countries. Measures to Reduce Road Dust Emissions from Traffic. Publication number 2016:790. Publish date 27.01.17, available at: https://www.norden.org/en/publication/road-dustand-pm10-nordic-countries (last accessed 4.11.2021), 2017.

Ovadnevaite J., Ceburnis D., Plauskaite-Sukiene K., Modini R., Dupuy R., Rimselyte I., Ramonet R., Kvietkus K., Ristovski Z., Berresheim H., O‘Dowd C.D.: Volcanic sulphate and arctic dust plumes over the North Atlantic Ocean. Atmospheric Environment 43, 4968-4974, 2009.

Peltoniemi, J. I., Gritsevich, M., Hakala, T., Dagsson-Waldhauserová, P., Arnalds, Ó., Anttila, K., Hannula, H.-R., Kivekäs, 1835 N., Lihavainen, H., Meinander, O., Svensson, J., Virkkula, A., and de Leeuw, G.: Soot on Snow experiment: bidirectional reflectance factor measurements of contaminated snow, The Cryosphere, 9, 2323-2337, https://doi.org/10.5194/tc-9-23232015, 2015.

Popova, E., Yool, A., Coward, A., Aksenov, Y., Alderson, S., Cuevas, B. d., and Anderson, T.: Control of primary production 1840 in the Arctic by nutrients and light: insights from a high resolution ocean general circulation model, Biogeosciences Discussions, 7, 5557-5620, 2010.

Popovicheva O., Diapouli E., Makshtas A., Shonija N., Manousakas M., Saraga D., Uttal T., Eleftheriadis K. East Siberian Arctic background and black carbon polluted aerosols at HMO Tiksi. Science of the Total Environment, № 655, c. 924-938 , 18452019 doi.org/10.1016/j.scitotenv.2018.11.165, 2019.

Price, H. C., et al.: Atmospheric Ice-Nucleating Particles in the Dusty Tropical Atlantic, J. Geophys. Res., 123(4), 2175-2193, doi:doi:10.1002/2017JD027560, 2018.

1850 Prospero, J.M., Bullard, J.E., Hodgkins, R.: High-latitude dust over the North Atlantic: inputs from Icelandic proglacial dust storms. Science 335, 1078-1082, 2012. 
Qin, Y., Abatzoglou, J.T., Siebert, S. et al.: Agricultural risks from changing snowmelt. Nat. Clim. Chang. 10, 459-465, https://doi.org/10.1038/s41558-020-0746-8, 2020.

Raiswell, R., Hawkings, J. R., Benning, L. G., Baker, A. R., Death, R., Albani, S., Mahowald, N., Krom, M. D., Poulton, S. W., and Wadham, J.: Potentially bioavailable iron delivery by iceberg-hosted sediments and atmospheric dust to the polar oceans, Biogeosciences, 13, 3887-3900, 2016.

Ranjbar, Keyvan,Norm T. O'Neill, Liviu Ivanescu, James King, Patrick L. Hayes, Remote sensing of a high-Arctic, local dust event over Lake Hazen (Ellesmere Island, Nunavut, Canada), Atmospheric Environment, 118102, ISSN 1352-2310, https://doi.org/10.1016/j.atmosenv.2020.118102, 2020.

Richards-Thomas T., Cheryl McKenna-Neuman, Ian M. Power, Particle-scale characterization of volcaniclastic dust sources within Iceland. Sedimentology, Volume68, Issue3, Pages 1137-1158, https://doi.org/10.1111/sed.12821, 2021.

Romanias M.N., Y. Ren, B. Grosselin, V. Daele, A. Mellouki, P. Dagsson-Waldhauserova, F. Thevenet: Reactive uptake of NO2 on volcanic particles: A possible source of HONO in the atmosphere, Journal of Environmental Sciences, Vol 95, pp 155-164, September 2020. DOI: 10.1016/j.jes.2020.03.042, 2020.

Ryan-Keogh, T. J., Macey, A. I., Nielsdottir, M. C., Lucas, M. I., Steigenberger, S. S., Stinchcombe, M. C., Achterberg, E. P., Bibby, T. S., and Moore, C. M.: Spatial and temporal development of phytoplankton iron stress in relation to bloom dynamics in the high-latitude North Atlantic Ocean, Limnology and Oceanography, 58, 533-545, doi: 10.4319/lo.2013.58.2.0533, 2013.

Rymer, K.: Aeolian activity in central Spitsbergen (Ebba Valley) in the years 2012-2017. In Proceedings of the XXXVII Polar Symposium "Polar Change_-Global Change", Poznan, Poland, 7-10 June 2018; p. 61, 2018.

Samonova O.A. and Aseyeva E.N.: Particle size partitioning of metals in humus horizons of two small erosional landforms in the middle Protva basin - a comparative study. GEOGRAPHY, ENVIRONMENT, SUSTAINABILITY. 2020;13(1):260-271. https://doi.org/10.24057/2071-9388-2019-116, 2020.

Sanchez-Marroquin, A. O. Arnalds, K. J. Baustian-Dorsi, J. Browse, P. Dagsson-Waldhauserova, A. D. Harrison, E. C. Maters, K. J. Pringle, J. Vergara-Temprado, I. T. Burke, J. B. McQuaid, K. S. Carslaw, B. J. Murray, Iceland is an episodic source of atmospheric ice-nucleating particles relevant for mixed-phase clouds. Science Advances 6(26), eaba8137, doi:10.1126/sciadv.aba8137, 2020. 
Šantl-Temkiv, T., R. Lange, D. Beddows, U. Rauter, S. Pilgaard, M. Dall'Osto, N. Gunde-Cimerman, A. Massling, and H. Wex: Biogenic Sources of Ice Nucleating Particles at the High Arctic Site Villum Research Station, Environ. Sci. Technol., 53(18), 10580-10590, doi:10.1021/acs.est.9b00991, 2019.

Schroth, A. W., Crusius, J., Gasso, S., Moy, C. M., Buck, N. J., Resing, J. A., and Campbell, R. W.: Atmospheric deposition of glacial iron in the Gulf of Alaska impacted by the position of the Aleutian Low, Geophysical Research Letters, 44, 50535061, doi: 10.1002/2017g1073565, 2017.

1895 Schuler, T. V., Kohler, J., Elagina, N., Hagen, J. O. M., Hodson, A. J., Jania, J. A., Kääb, A. M., Luks, B., Małecki, J., Moholdt, G., Pohjola, V. A., Sobota, I., and Van Pelt, W. J. J.: Reconciling Svalbard Glacier Mass Balance, Front Earth Sci., 8, 156, https://doi.org/10.3389/feart.2020.00156, 2020.

Semenkov, I. N. and Koroleva, T. V.: The spatial distribution of fractions and the total content of 24 chemical elements in soil 1900 catenas within a small gully's catchment area in the Trans Urals, Russia, Appl. Geochemistry, 106, 1-6, doi:10.1016/j.apgeochem.2019.04.010, 2019.

Semenkov, I. and Yakushev, A.: Dataset on heavy metal content in background soils of the three gully catchments at Western Siberia, Data Br., doi:10.1016/j.dib.2019.104496, 2019.

Semenkov, I. N., Usacheva, A. A. and Miroshnikov, A. Y.: Distribution of global fallouts cesium-137 in taiga and tundra catenae at the Ob River basin, Geol. Ore Depos., 57(2), 138-155, doi:10.1134/S1075701515010055, 2015a.

Semenkov, I. N., Miroshnikov, A. Y., Asadulin, E. E., Usacheva, A. A., Velichkin, V. I. and Laverov, N. P.: The Ob river basin as a source of Kara Sea contamination with global fallout of Cesium-137, Dokl. Earth Sci., 463(1), 704-706, doi:10.1134/S1028334X1507003X, 2015b.

Semenkov, I. N., Krupskaya, V. and Klink, G.: Data on the concentration of fractions and the total content of chemical elements in catenae within a small catchment area in the Trans Urals, Russia, Data in Brief, 29, doi:10.1016/j.dib.2019.104224, 2019.

Semenkov, I. N., Sharapova, A. V., Koroleva, T. V., Klink, G. V., Krechetov, P. P. and Lednev, S. A.: Nitrogen-containing substances in the falling regions of the Proton launch vehicle in 2009 -2019, Led i sneg, 1, In press, 2021. 
Sharapova, A. V., Semenkov, I. N., Koroleva, T. V., Krechetov, P. P., Lednev, S. A. and Smolenkov, A. D.: Snow pollution 1920 by nitrogen-containing substances as a consequence of rocket launches from the Baikonur Cosmodrome, Sci. Total Environ., 709, 136072, doi:10.1016/j.scitotenv.2019.136072, 2020.

Shi, Z., Krom, M. D., Jickells, T. D., Bonneville, S., Carslaw, K. S., Mihalopoulos, N., Baker, A. R., and Benning, L. G.: Impacts on iron solubility in the mineral dust by processes in the source region and the atmosphere: A review, Aeolian 1925 Research, 5, 21-42, doi: 10.1016/j.aeolia.2012.03.001, 2012.

Shugar, D. H., Clague, J. J., Best, J. L., Schoof, C., Willis, M. J., Copland, L., Roe, G. H.: River piracy and drainage basin reorganization led by climate-driven glacier retreat. Nature Geoscience 10:370, 2017.

1930 Sofiev, M., Vira, J., Kouznetsov, R., Prank, M., Soares, J., Genikhovich, E.: Construction of the SILAM Eulerian atmospheric dispersion model based on the advection algorithm of Michael Galperin, Geosci. Model Developm. 8, 3497-3522, 2015.

Speirs, J.C., McGowan, H.A. and Neil, D.T. Meteorological controls on sand transport and dune morphology in a polar-desert: Victoria Valley, Antarctica. Earth Surf. Proc. Land., 33, 1875-1891, 2008.

Spolaor A, Moroni B, Luks B, Nawrot A, Roman M, Larose C, Stachnik Ł, Bruschi F, Kozioł K, Pawlak F, Turetta C, Barbaro E, Gallet J-C and Cappelletti D. Investigation on the Sources and Impact of Trace Elements in the Annual Snowpack and the Firn in the Hansbreen (Southwest Spitsbergen). Front. Earth Sci. 8:536036. doi: 10.3389/feart.2020.536036, 2021.

1940 Stockdale, A., Krom, M. D., Mortimer, R. J., Benning, L. G., Carslaw, K. S., Herbert, R. J., Shi, Z., Myriokefalitakis, S., Kanakidou, M., and Nenes, A.: Understanding the nature of atmospheric acid processing of mineral dusts in supplying bioavailable phosphorus to the oceans, Proc Natl Acad Sci U S A, 113, 14639-14644, doi: 10.1073/pnas.1608136113, 2016.

Stojiljkovic, A., Kauhaniemi, M., Kukkonen, J., Kupiainen, K., Karppinen, A., Denby, B. R., Kousa, A., Niemi, J. V., and

1945 Ketzel, M.: The impact of measures to reduce ambient air PM10 concentrations originating from road dust, evaluated for a street canyon in Helsinki, Atmos. Chem. Phys., 19, 11199-11212, https://doi.org/10.5194/acp-19-11199-2019, 2019.58-9, 2019.

Storelvmo, T., I. Tan, and A. V. Korolev: Cloud Phase Changes Induced by CO2 Warming — a Powerful yet Poorly Constrained 1950 Cloud-Climate Feedback, Current Climate Change Reports, 1(4), 288-296, doi:10.1007/s40641-015-0026-2, 2015. 
Tagliabue, A., and Arrigo, K. R.: Iron in the Ross Sea: 1. Impact on CO2 fluxes via variation in phytoplankton functional group and non-Redfield stoichiometry, Journal of Geophysical Research: Oceans, 110, 2005.

1955 Tan, I., and T. Storelvmo: Evidence of Strong Contributions From Mixed-Phase Clouds to Arctic Climate Change, Geophys. Res. Lett., 46(5), 2894-2902, doi:https://doi.org/10.1029/2018GL081871, 2019

Tarr, R. S., and L. Martin. Glacier deposits of the continental type in Alaska, Geology, 21, 289-300, https://doi.org/10.1086/622063, 1913.

Taylor, R. L., Semeniuk, D. M., Payne, C. D., Zhou, J., Tremblay, J. É., Cullen, J. T., and Maldonado, M. T.: Colimitation by light, nitrate, and iron in the Beaufort Sea in late summer, Journal of Geophysical Research: Oceans, 118, 3260-3277, 2013.

Television Midtvest 2021, Se videoen: Kraftig blæst får biler til at forsvinde i støvsky | TV MIDTVEST, 2021.

Tobo, Y. K. Adachi, P. J. DeMott, T. C. J. Hill, D. S. Hamilton, N. M. Mahowald, N. Nagatsuka, S. Ohata, J. Uetake, Y. Kondo, M. Koike: Glacially sourced dust as a potentially significant source of ice nucleating particles. Nat Geosci 12(4), 253258, doi:10.1038/s41561-019-0314-x, 2019.

Urupina D., Lasne, J., Romanias, M., Thiery, V., Dagsson-Waldhauserova, P., Thevenet, F.: Uptake and surface chemistry of SO2 on natural volcanic dusts, Atmospheric Environment, Vol 217, pp 116942, DOI: 10.1016/j.atmosenv.2019.116942, 2019.

UNCCD / Vukovic, A. (2021): Sand and Dust Storms Source Base-map. Visualization Tool. https://maps.unccd.int/sds/ and https://www.youtube.com/watch?v=4tsbspJvuAs, 2021.

USGCRP 2018. Impacts, Risks, and Adaptation in the United States: The Fourth National Climate Assessment, Volume II. (D. R. Reidmiller, C. W. Avery, D. R. Easterling, K. E. Kunkel, K. L. M. Lewis, T. K. Maycock, and B. C. Stewart, Eds.). Washington, DC. https://doi.org/10.7930/NCA4.2018, 2018.

1980 Usher, C.R., Michel, A.E., and Grassian, V.H.: Chemical Reviews,103, 12, 4883-4940, DOI: 10.1021/cr020657y, 2003.

Valle, H. F. Del, Elissalde, N. O., Gagliardini, D. A., and Milovich, J.: Status of desertification in the Patagonian region: Assessment and mapping from satellite imagery. Arid Soil Research and Rehabilitation, 12(2), 95-121. https://doi.org/10.1080/15324989809381502, 1998 . 
https://doi.org/10.5194/acp-2021-963

Preprint. Discussion started: 17 December 2021

(C) Author(s) 2021. CC BY 4.0 License.

(c) (P)
Atmospheric

Chemistry

and Physics

Discussions

Varga, G., Dagsson-Waldhauserová, P., Gresina, F. and Helgadottir A.: Saharan dust and giant quartz particle transport towards Iceland. Scientific Reports 11, 11891, 2021.

Vergara-Temprado, J., A. K. Miltenberger, K. Furtado, D. P. Grosvenor, B. J. Shipway, A. A. Hill, J. M. Wilkinson, P. R. 1990 Field, B. J. Murray, and K. S. Carslaw: Strong control of Southern Ocean cloud reflectivity by ice-nucleating particles, P. Natl. Acad. Sci. USA, doi:10.1073/pnas.1721627115, 2018.

Vukovic, A.: Report on consultancy to develop Global Sand and Dust Source Base Map, no. CCD/18/ERPA/21, UNCCD, 2019.

Vukovic Vimic, A.: Global high-resolution dust source map, InDust webinar, 21 April 2021, https://costindust.eu/events/indust-events, 2021.

Wahlström E., Reinikainen, T. and Hallanaro E.-L. Ympäristön tila Suomessa, ISBN 951-662-523-1, 364 p., 1996

Wientjes, I. G., R. S. Van De Wal, G. J. Reichart, A. Sluijs, and J. Oerlemans. 2011. Dust from the dark region in the western ablation zone of the Greenland ice sheet. The Cryosphere 5:589-601. doi:10.5194/tc-5-589-2011.

Winton, V. H. L., Dunbar, G. B., Bertler, N. A. N., Millet, M. A., Delmonte, B., Atkins, C. B., Chewings, J. M., and Andersson,

P.: The contribution of aeolian sand and dust to iron fertilization of phytoplankton blooms in southwestern Ross Sea, Antarctica, Global Biogeochemical Cycles, 28, 423-436, doi: 10.1002/2013gb004574, 2014.

Winton, V. H. L., Edwards, R., Delmonte, B., Ellis, A., Andersson, P. S., Bowie, A., Bertler, N. A. N., Neff, P., and Tuohy, A.: Multiple sources of soluble atmospheric iron to Antarctic waters, Global Biogeochemical Cycles, 30, 421-437, doi: $10.1002 / 2015 \mathrm{gb} 005265,2016$.

Winton, V.H.L., Dunbar, G.B., Atkins, C.B., Bertler, N.A.N., Delmonte, B., Andersson, P., Bowie, A., Edwards, R., (2016). The origin of lithogenic sediment in the south-western Ross Sea and implications for iron fertilization. Antarctic Science. doi:10.1017/S095410201600002X, 2016.

Wolfe S.A., Cold-Climate Aeolian Environments, Reference Module in Earth Systems and Environmental Sciences, 10.1016/B978-0-12-818234-5.00036-5, (2020). 
https://doi.org/10.5194/acp-2021-963

Preprint. Discussion started: 17 December 2021

(c) Author(s) 2021. CC BY 4.0 License.

(c) (1)

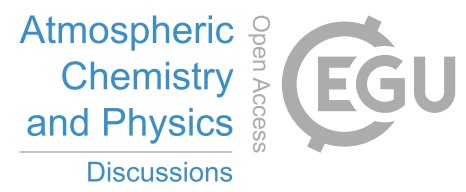

Zhu, L., Ives, A., Zhang, C., Guo, Y., and Radeloff, V.: Climate change causes functionally colder winters for snow cover2020 dependent organisms. Nature Climate Change. 9. 1-8. 10.1038/s41558-019-0588-4, 2019.

Zhu, Y., Toon, O.B., Jensen, E.J. et al.: Persisting volcanic ash particles impact stratospheric $\mathrm{SO}_{2}$ lifetime and aerosol optical properties. Nat Commun 11, 4526, https://doi.org/10.1038/s41467-020-18352-5, 2020.

2025 Zwoliński, Z., Kostrzewski, A., and Pulina, M. (Eds.): Dawne i współczesne geoekosystemy Spitsbergenu [Ancient and modern geoecosystems of Spitsbergen], Bogucki Wydawnictwo Naukowe, Poznań, 456 pp., 2013. 